\title{
Classical and Molecular Approaches to Breeding Horticultural Plants for Disease Resistance
}

\author{
held at the \\ 91st ASHS Annual Meeting \\ Corvallis, Ore. \\ 8 Aug. 1994
}

\begin{abstract}
sponsored by the
Vegetable Breeding Working Group

Genetics and Germplasm Working Group

Fruit Breeding Working Group

Ornamental Plant Breeding Working Group
\end{abstract}

published by the

American Society for Horticultural Science

Alexandria, VA 22314-2824

as a special insert in

HortScience 30(3), June 1995 


\title{
Colloquium Papers and Authors
}

\author{
Presiding: Dermot P. Coyne
}

Classical and Molecular Approaches to Breeding Horticultural Plants for Disease Resistance: Introduction to the Colloquium

Dermot P. Coyne

\section{Genetic Engineering for Crop Virus Resistance}

Rebecca Grumet

\author{
Novel Approaches for Genetic Resistance to Bacterial Pathogens in Flower Crops \\ Adelheid R. Kuehnle, Fure-Chyi Chen, and Nellie Sugii
}

Use of Random Amplified Polymorphic DNA Markers in Breeding for Major Gene Resistance to Plant Pathogens

James D. Kelly

Classical and Molecular Approaches to Breeding Fruit and Nut Crops for Disease Resistance

Shawn A. Mehlenbacher

Statistical Analysis of Disease Reaction Data Using Nonparametric Methods

K.M. Eskridge

\section{Classical and Molecular Approaches to Breeding Horticultural Plants for Disease Resistance: Introduction to the Colloquium}

\author{
Dermot P. Coyne \\ Department of Horticulture, University of Nebraska, Lincoln, NE 68583-0724
}

\begin{abstract}
Diseases of horticultural crops have always been a concern of crop producers, processors, merchandisers, and consumers because of reductions in yield and product quality. Excessive chemical application to control diseases of some crops has been a health concern in some countries. Some diseases pose a major constraint, or even a threat, to the production of a crop in a region. Plant breeders, in association with plant pathologists, have had notable successes in breeding disease-resistant varieties, thus ensuring the economic production of a crop. There is now an increased need to breed for disease resistance of horticultural crops because of a loss of chemicals for disease control, environmental and human health concerns, the need to enhance economic competitiveness of horticultural producers and to reduce the genetic vulnerability of crops to pathogens, and an emphasis on using sustainable crop production systems. It is timely to review new concepts and strategies in breeding for disease resistance in horticultural crops in view of the new technologies that have been developed along with the continuing role of classical breeding. This
\end{abstract}

Received for publication 20 Oct. 1994. Accepted for publication 6 Dec. 1994 I thank J. Nienhuis, L. Wessel-Beaver, Carol Robacher, O. Rogers, R. Bell, and P. Simon for their advice. The information provided by the following members of an ad hoc committee to develop this colloquium is appreciated: P. Gepts, R. Grumet, J. Nienhuis, Kanti Rawal, and Norman Weeden. Clarice Coyne and Pat Breen assisted with local arrangements for this colloquium. Their efforts are appreciated. The cost of publishing this paper was defrayed in part by the payment of page charges. Under postal regulations, this paper therefore must be hereby marked advertisement solely to indicate this fact. colloquium was organized to review recent developments in classical and molecular approaches to breeding diverse horticultural plants for resistance to viruses, bacteria, and fungi. The reviews embody concepts, methods, strategies, and examples of current developments and successes that will interest breeders of all horticultural crops.

A comprehensive classical breeding program for disease resistance involving cooperation between breeders and pathologists encompasses most or all of the following areas: knowledge of the biology, strain, variation and virulence, and epidemiology of the pathogen; development of rapid inoculation methods with repeatable results; use of sets of differential varieties/lines (where available) to provide information on strain variation; easily applied and understood disease rating scales; identification of sources of resistance; knowledge of the genetics of resistance; development of effective selection and breeding schemes for resistance; and widespread evaluation of new lines along with controls in production areas to determine merit for release.

Many graduate students in plant breeding are now heavily involved in using the tools of molecular biology and tissue culture (molecular markers, gene tagging, molecular mapping, transformation methods, and regeneration of specific tissues into intact plants) in the laboratory. They also need to be well versed in the disciplines associated with classical breeding programs. The new tools need to become a part of the total plant breeding program. At this stage, breeders need to combine molecular and classical approaches in enhancing germplasm and developing crop varieties with desirable horticultural traits along with disease resistance. The goal of plant breeding is to enhance the 
welfare of a society through genetic improvement of crops, while at the same time improving breeding methods and advancing knowledge in attaining that goal. This perspective needs to be imparted to graduate students, administrators of land-grant institutions, and funding agencies because of the continued erosion of plant breeding programs. It is imperative for the future well-being of humanity that we continue to train plant breeders to meet the stated goal.

In some cases, sufficiently high levels of resistance to some pathogens of many crops have not been secured through classical breeding. In this category are physiological resistance to the fungus Sclerotinia sclerotiorum [(Lib.) de Bary], some gemini viruses, and bacterial pathogens. Molecular approaches alone, or in combination with classical breeding, may be the most useful approach to attain a desired resistance level. Breeding for virus resistance has proved to be long, difficult, and costly in some crops. Transgenic plants with high levels of resistance to some virus diseases have been developed in recent years through insertion of a gene controlling the virus coat protein into a host genome (see review by R. Grumet). This goal can be achieved in a short time in comparison with traditional breeding procedures. Grumet also discusses other strategies to develop transgenic virus-resistant plants.

Classical breeding procedures have not been successful in introducing high levels of resistance to some bacterial pathogens into acceptable crop lines or varieties. The recent introduction of foreign genes that control specific peptides with antibacterial properties from nonplant sources into desired susceptible horticultural varieties may provide high levels of resistance to a broad spectrum of bacterial pathogens (see review by A.K. Kuehnle). This approach is particularly valuable where it is desired to maintain the original genotype of the variety, except for the introduced foreign gene, and where the classical backcross method is difficult to use or cannot be used to constitute the genotype due to incompatibility, as in apple (Malus domestica Borkh.) (see review by S.M. Mehlenbacher).

If an introduced foreign gene does not provide a high enough level of disease resistance, it may be useful to determine if enhanced levels of resistance can be obtained by combining the foreign gene with genes for moderate resistance that accumulated in lines through classical breeding procedures. The stability of expression of the foreign gene and its expression in the desired plant parts also must be determined.

Gene pyramiding to combine resistance to various races of a pathogen to enhance durability of resistance and to reduce genetic vulnerability to the pathogen has been difficult using classical procedures. The difficulty resides in the repeated testing needed with strains to identify the required genes and in the problem of epistasis of genes, which requires test crosses to detect the hypostatic gene. The use of RAPD molecular markers to "tag" genes for resistance to various strains of rust and bean common mosaic virus is now being used by J.D. Kelly (see review paper) to pyramid genes for resistance to strains of those pathogens in common beans (Phaseolus vulgaris L.). Selection for resistance to the above pathogens using molecular markers in the absence of the disease likely also will be practicable.

Breeding for resistance to a pathogen whose inheritance is complex and of low heritability may be difficult using classical breeding procedures. Molecular-marker-assisted selection (MAS) may be more efficient than phenotypic selection under certain conditions. This procedure probably will require detection of quantitative trait loci (QTLs) that would explain a major portion of the variability for the trait. If the heritability of the trait can be increased through improved screening procedures and if appropriate population sizes are used, then QTL detection will be improved.

Mehlenbacher provides a broad overview of current developments in breeding small fruit and tree fruit using classical methods, molecular mapping, MAS, and transformation procedures. He also discusses the role of classical and molecular approaches in breeding crop plants and the current status of plant breeding in public institutions in the United States.

The colloquium concluded with a presentation by Eskridge (see review paper) dealing with the use of nonparametric statistical methods, because data obtained from experiments dealing with disease reactions do not adhere to the standard assumptions underlying the classical analysis of variance. Examples are provided of the value of using nonparametric procedures vs. parametric methods. Detecting more disease-resistant lines to various pathogens in diverse situations is possible using nonparametric methods (Eskridge).

This colloquium is broad in scope and contains subject matter of interest to all breeders of horticultural plants. The information should be especially useful to those involved in teaching graduate courses in plant breeding and for graduate students entering the profession, because it contains "state of the art" information on breeding for disease resistance.

\title{
Genetic Engineering for Crop Virus Resistance
}

\author{
Rebecca Grumet \\ Department of Horticulture, Michigan State University, East Lansing, MI 48824
}

The advances of the past decade in plant transformation and the genetic engineering of virus resistance have provided some of the most dramatic recent developments in our ability to increase genetic resistance to plant diseases. In fact, engineered virus resistance was one of the first successful demonstrations of the introduction of any agriculturally useful trait into plants (Gasser and Fraley, 1989). Engineered plant virus resistance remains a highly active area of research and development by public institutions and industry.

One of the major contributing factors to the early, rapid, and widespread development of genetically engineered virus resistance is the source of genes that are used. As will be discussed further, with the exception of some recent experiments with animal-based systems (antibodies, Tavladoraki et al., 1993; interferon-related proteins, Truve et al., 1993), in every case the genes that were used came from the

Received for publication 20 Oct. 1994. Accepted for publication 16 Nov. 1994. I thank Jim Kelly and Robert Herner for their helpful reviews of the manuscript. The cost of publishing this paper was defrayed in part by the payment of page charges. Under postal regulations, this paper therefore must be hereby marked advertisement solely to indicate this fact. genome of the virus (Table 1). To my knowledge, there are no examples at this time where engineered virus resistance was achieved using a gene from the host. The practical significance of our ability to use viral genes is that they generally are easy to clone. The use of such genes, however, is only possible with the concurrent development of appropriate plant transformation technologies.

In the past 8 years, there have been more than 70 reports of genetically engineered virus resistance. The number of plant viruses for which engineered resistance has been achieved, the number of plant species into which these genes have been introduced, and the types of genes that have been used are increasing rapidly. This review focuses on the progress that has been made toward the development of virus-resistant crops and will emphasize applied aspects of the work rather than discussions of mechanism. I will use various examples, including those from my laboratory group, to illustrate different aspects of the engineered resistance. Recent reviews related to this topic include those by Beachy et al. (1990), Fitchen and Beachy (1993), Gandani et al. (1990), Grumet (1990, 1994), Hull and Davies (1992), Nelson et al. (1990), Scholtof et al. (1993), and Wilson (1993).

To develop an engineered crop with an agriculturally useful trait, 
Table 1. Types of genes that have been used to genetically engineer virus resistance in plants.

\begin{tabular}{|c|c|c|c|}
\hline Type of gene & Source & First example & $\begin{array}{c}\text { No. } \\
\text { examples }^{2}\end{array}$ \\
\hline Coat protein & Virus & 1986-Powell-Abel et al. & 44 \\
\hline Satellite & $\begin{array}{l}\text { Virus- } \\
\text { associated }\end{array}$ & $\begin{array}{l}\text { 1987—-Gerlach et al. } \\
\text { 1987—Harrison et al. }\end{array}$ & 6 \\
\hline $\begin{array}{l}\text { Antisense, sense } \\
\text { defective RNAs }\end{array}$ & Virus & $\begin{array}{l}\text { 1988-Cuozzo et al. } \\
\text { 1988-Hemenway et al. }\end{array}$ & 15 \\
\hline $\begin{array}{l}\text { Replicase } \\
\text { Defective-interfering }\end{array}$ & Virus & 1990_Golemboski et al. & 8 \\
\hline sequences & Virus & 1990—Stanley et al. & 3 \\
\hline Movement protein & Virus & 1993-Malysheko et al. & 1 \\
\hline Protease & Virus & 1993_Vardi et al. & 1 \\
\hline Antibody & Animal & 1993-Tavladoraki et al. & 1 \\
\hline $\begin{array}{l}\text { Interferon-related } \\
\text { protein }\end{array}$ & Animal & 1993-Truve et al. & 1 \\
\hline
\end{tabular}

two components must come together: a suitable transformation system and useful genes. Although transformation per se is not within the focus of this discussion, and I will not describe the various methods, I do not want to ignore its importance, for it can be a limiting factor. For each crop of interest, it is necessary to develop the appropriate regeneration and transformation technologies; depending on the species in question, this can be very challenging. In fact, until 1991, all published examples of genetically engineered virus resistance were in either tobacco (Nicotiana tabacum L.) or related Nicotiana species, or tomato, or potato; i.e., Solanaceous species that are comparatively easy to transform. Progress is being made, however, as more crops receive effort. In the past few years, examples have been published for other diverse crops (Fang and Grumet, 1993; Fitch et al., 1992; Gonsalves et al., 1992, 1994; Hayakawa et al., 1992; Hill et al., 1991; Murray et al., 1993; Zaccomer et al., 1993) (Table 2).

The second critical component is the gene to be transferred. As noted, with regard to engineered virus resistance, in almost every case the source of resistance genes has been the virus itself. The theoretical basis for the use of virus-derived genes as a source of resistance genes has been termed pathogen-derived resistance (Sanford and Johnston, 1985). The concept of pathogen-derived resistance states that it should be possible to disrupt the normal life cycle of a pathogen by causing the host to express a pathogen gene at the wrong time, in the wrong amount, or in a counterfunctional form. Either native or altered viralderived genes might be used to interfere with various stages in the viral life cycle, such as uncoating, translation, replication, cell-to-cell or long-distance movement, or vector-mediated transmission.

Table 2. Plant species that have been genetically engineered for virus resistance.

\begin{tabular}{|c|c|c|}
\hline Species & $\begin{array}{l}\text { No. published } \\
\text { examples }\end{array}$ & Viruses $^{2}$ \\
\hline $\begin{array}{l}\text { Tobacco } \\
\text { (Nicotiana tabacum L.) }\end{array}$ & 37 & $\begin{array}{l}\text { AlMV, ArMV, CMV } \\
\text { PVX, PVY, TEV } \\
\text { TGMV, TMV, TRV } \\
\text { TSV, TSWV }\end{array}$ \\
\hline $\begin{array}{l}\text { Other Nicotiana } \mathrm{spp} \text {. } \\
\text { (N. debneyii, N. benthamiana, } \\
\quad \text { N. clevelandii) }\end{array}$ & 12 & $\begin{array}{l}\text { ACMV, BYMV, CyMV } \\
\text { CyRSV, BCTV, PEBV } \\
\text { PPV, PVS, WMV }\end{array}$ \\
\hline $\begin{array}{l}\text { Potato (Solanum tuberusom L.) } \\
\text { Tomato }\end{array}$ & 10 & PLRV, PVY \\
\hline (Lycopersicon esculentum L.) & 5 & AlMV, CMV, TMV, TYLCV \\
\hline Cucumber (Cucumis sativus L.) & 1 & CMV \\
\hline Melon (Cucumis melo L.) & 2 & CMV, ZYMV \\
\hline Alfalfa (Medicago sativa $\mathrm{L})$. & 1 & AlMV \\
\hline Papaya (Carica papaya L.) & 1 & PRSV \\
\hline Corn (Zea mays L.) & 1 & MDMV \\
\hline Rice (Oryza sativa L.) & 1 & RSV \\
\hline Rapeseed (Brassica napus L.) & 1 & TYMV \\
\hline
\end{tabular}

${ }^{2}$ See Tables 3-6 for references and complete virus names.
The use of pathogen-derived resistance can be contrasted with conventional breeding, which, of necessity, relies on host genes that can be transferred between interfertile relatives. Clearly, great progress has been made in developing virus-resistant cultivars for a range of crops and viruses using conventional methods (e.g., Kyle, 1993). Undoubtedly, conventional breeding will continue to play a dominant role in the future production of virus-resistant crops. There can, however, be limitations to conventional breeding approaches. The desired resistance is not always available in a closely related, interfertile relative; the genes for resistance may be tightly linked to undesirable traits; or the resistance may be multigenic and difficult to transfer (Knott and Dvorak, 1976; Wenzel, 1985).

From a genetic engineering standpoint, the use of viral genes has several advantages. Viruses have tiny genomes and short life cycles, thereby making it easy to identify, isolate, and clone a given viral gene. In contrast, most plant species have large genomes, large amounts of repetitive DNA, and, despite active, ongoing efforts, are not well mapped. Furthermore, in the great majority of cases, the underlying mechanism of resistance is not known; thus, there is no tag by which to identify and isolate the resistance genes. All of these features make cloning a host-encoded resistance gene difficult.

Even when using virus-encoded genes, several steps are involved in developing a transgenic, virus-resistant plant. First, the virus must be purified and the viral RNA or DNA isolated. For an RNA virus (note that $>90 \%$ of plant viruses have RNA genomes; Zaitlin and Hull, 1987), the isolated viral RNA is used as a template for reverse transcriptase to produce a cDNA copy of the viral genome. The viral gene(s) must then be identified, sequenced, and engineered into an expression vector that will facilitate expression in plants. These steps include adding transcriptional and, possibly, translational information; if transformation is to be done using Agrobacterium, Ti borders also will be added. Transformation methods most commonly used include Agrobacterium-mediated transformation or particle bombardment. Since only a fraction of a percent of the exposed cells will become transformed, the transformation plasmid generally also includes a selectable marker gene for antibiotic resistance, thereby enabling only those cells that express the introduced gene to grow, divide, and regenerate on medium containing the appropriate antibiotic.

Successful transformation is verified by testing for incorporation of the introduced gene into the host chromosome by Southern blot, polymerase chain reaction analysis, or both, and by verification of transfer to the next generation. Expression of the gene is verified by analyzing for production of the expected mRNA (northern blot) and protein [western blot or enzyme-linked immunosorbent assay (ELISA)]. As with any introduced gene, not all transgenic plants express a given viral gene construct to the same extent. This variation can have importance when selecting lines that exhibit the greatest resistance, but note that there is not always a direct correlation between levels of gene expression and resistance, as will be discussed later.

\section{EXAMPLES OF ENGINEERED RESISTANCE TO VIRUSES}

\section{Coat protein-mediated resistance}

The first example of genetically engineered plant virus resistance was published in 1986 (Powell-Abel et al., 1986). The coat protein (CP) gene from tobacco mosaic virus (TMV) was inserted into tobacco and the resultant transgenic plants, which constitutively produced viral coat protein, were more resistant to infection by TMV than were control, nontransgenic plants. The coat protein-mediated approach to engineer resistance has proved to be widely applicable to a range of viruses, including positive sense, negative sense, single-, and doublestranded RNA viruses, and at least one DNA virus (Table 3). The viruses differ in particle morphology, genome organization, and mode of transmission, and represent at least 13 different virus groups. Abbreviations of virus names will be used throughout the text; the full names are listed in Tables 3, 5, 6, and 7 .

The extent of protection conferred by the $\mathrm{CP}$ genes is variable, depending on the type of virus and the individual transgenic line. In general, following inoculation with the virus from which the $\mathrm{CP}$ gene 
Table 3. Genetically engineered plant virus resistance using viral coat protein genes.

\begin{tabular}{|c|c|c|c|c|}
\hline Virus group & Virus & Abbreviation & Host species & Reference \\
\hline \multirow[t]{4}{*}{ Alfalfa mosaic virus group } & Alfalfa mosaic virus & AlMV & Tobacco & Loesch-Fries et al., 1987 \\
\hline & & & Tobacco & van Dun et al., 1987 \\
\hline & & & Tobacco, tomato & Tumer et al., 1987 \\
\hline & & & Alfalfa & Hill et al., 1991 \\
\hline \multirow[t]{2}{*}{ Carlavirus } & Potato virus $\mathrm{S}$ & PVS & Nicotiana debneyii & Mackenzie and Tremaine, 1990 \\
\hline & & & Potato & Mackenzie et al., 1991 \\
\hline \multirow[t]{5}{*}{ Cucumovirus } & Cucumber mosaic virus & CMV & Tobacco & Cuozzo et al., 1988 \\
\hline & & & Tobacco & Quemada et al., 1991 \\
\hline & & & Tobacco & Nakajima et al., 1993 \\
\hline & & & Cucumber & Gonsalves et al., 1992 \\
\hline & & & Melon & Gonsalves et al., 1994 \\
\hline Geminivirus & Tomato yellow leaf curl virus & TYLCV & Tomato & Kunick et al., 1994 \\
\hline Ilarvirus & Tobacco streak virus & TSV & Tobacco & van Dun et al., 1988 \\
\hline \multirow[t]{3}{*}{ Luteovirus } & Potato leafroll virus & PLRV & Potato & Kawchuk et al., 1990 \\
\hline & & & Potato & van der Wilk et al., 1991 \\
\hline & & & Potato & Barker et al., 1992 \\
\hline \multirow[t]{2}{*}{ Nepovirus } & Arabis mosaic virus & ArMV & Tobacco & Bertiolo et al., 1992 \\
\hline & Grapevine chrome mosaic virus & GCMV & Tobacco $^{z}$ & Brault et al., 1993 \\
\hline \multirow[t]{6}{*}{ Potexvirus } & Cymbidium mosaic virus & СуMV & N. benthamiana ${ }^{z}$ & Chia et al., 1992 \\
\hline & Potato virus $\mathrm{X}$ & PVX & Tobacco & Hemenway et al., 1988 \\
\hline & & & Potato & Hoekema et al., 1989 \\
\hline & & & Potato & Kaniewski et al., 1990 \\
\hline & & & Potato & Lawson et al., 1990 \\
\hline & & & Potato & Jongedijk et al., 1992 \\
\hline \multirow[t]{12}{*}{ Potyvirus } & Bean yellow mosaic virus & BYMV & N. benthamiana & Hammond and Kamo, 1993 \\
\hline & Lettuce mosaic virus & LMV & Tobacco $^{y}$ & Dinant et al., 1993 \\
\hline & Maize dwarf mosaic virus & MDMV & Corn & Murray et al., 1993 \\
\hline & Papaya ringspot virus & PRSV & Tobacco $^{y}$ & Ling et al., 1991 \\
\hline & & & Papaya & Fitch et al., 1992 \\
\hline & Plum pox virus & PPV & N. clevelandii & Regner et al., 1992 \\
\hline & Potato virus Y & PVY & Potato & Lawson et al., 1990 \\
\hline & & & Potato & Kaniewski et al., 1990 \\
\hline & Soybean mosaic virus & SMV & Tobacco $^{y}$ & Stark and Beachy, 1989 \\
\hline & Watermelon mosaic virus & WMV & N. benthamiana & Namba et al., 1992 \\
\hline & Zucchini yellow mosaic virus & ZYMV & N. benthamiana ${ }^{y}$ & Namba et al., 1992 \\
\hline & & & Melon, tobacco & Fang and Grumet, 1993 \\
\hline Tenuivirus & Rice stripe virus & RSV & Rice & Hayakawa et al., 1992 \\
\hline \multirow[t]{3}{*}{ Tobamovirus } & Tobacco mosaic virus & TMV & Tobacco & Powell-Abel et al., 1986 \\
\hline & & & Tomato & Nelson et al., 1988 \\
\hline & & & Tomato & Sanders et al., 1992 \\
\hline & Tobacco rattle virus & TRV & Tobacco & van Dun and Bol, 1988 \\
\hline \multirow[t]{3}{*}{ Tospovirus } & Tomato spotted wilt virus & TSWV & Tobacco & Gielen et al., 1991 \\
\hline & & & Tobacco & Pang et al., 1992 \\
\hline & & & Tobacco & MacKenzie and Ellis, 1992 \\
\hline
\end{tabular}

${ }^{2}$ The virus does not move systemically in this host.

yonly tested against heterologous viruses.

was derived, the inoculated leaves of the transgenic plants show 1) fewer viral lesions than do control plants; 2) systemic spread of infection is prevented, delayed, or reduced; or 3) both occur. In the majority of cases, virus accumulation is reduced or absent. For example, transgenic zucchini yellow mosaic virus (ZYMV) $\mathrm{CP}$ expressing melon plants did not show symptoms for up to 90 days after infection with ZYMV, nor were there detectable levels of virus accumulation (Fang and Grumet, 1993).

In some cases, the level of protection is related to the level of $\mathrm{CP}$ expression, e.g., alfalfa mosaic virus (AlMV) (Hill et al., 1991; Loesch-Fries et al., 1987), potato virus X (PVX) (Hemenway et al., 1988; Hoekema et al., 1989), rice stripe virus (RSV) (Hayakawa et al., 1992), and tomato yellow leaf curl virus (TYLCV) (Kunik et al., 1994). Comparisons among individual lines with different levels of expression, or between heterozygotes and homozygotes, indicate that higher levels of CP provide greater protection. Similarly, reduction of TMV CP levels by heat treatment resulted in reduced protection against TMV infection (Nejidat and Beachy, 1989). For other viruses, however, there is not necessarily a correlation between CP level and level of resistance, e.g., certain potyviruses (Lawson et al., 1990; Namba et al., 1992; Regner et al., 1992), luteoviruses (Kawchuk et al., 1990), and tospoviruses (Gielen et al., 1991; MacKenzie and Ellis, 1992; Pang et al., 1992). Protection against ZYMV also was not correlated with the level of protein expression (Fang and Grumet, 1993).

In many cases, it has been possible to overcome the CP-mediated resistance with increasing concentrations of viral inocula, e.g., TMV (Powell-Abel et al., 1986), AlMV (Tumer et al., 1987), tomato spotted wilt virus (MacKenzie and Ellis, 1992), soybean mosaic virus (Stark and Beachy, 1989), watermelon mosaic virus (WMV) (Namba et al., 1992), and ZYMV (Grumet et al., 1994). However, similar levels of resistance were observed over a range of inoculum levels for several viruses, including cucumber mosaic virus (CMV) (Cuozzo et al., 1988), arabis mosaic virus (Bertioli et al., 1992), potato leafroll virus (PLRV) (Kawchuk et al., 1990), and potato virus S (Mackenzie and Tremaine, 1990; MacKenzie et al., 1991). From an applied point of view, higher levels of protection would be most valuable, but perhaps the most critical factor is whether the levels of resistance are sufficient relative to inoculum concentrations likely to be encountered in the field.

The issue of inoculum concentration is particularly relevant to vector-mediated transmission. In the majority of experiments, resistance assays were performed by rub inoculation. Where it has been tested, however, CP-mediated protection also is effective against insect-vectored transmission (Table 4). In some cases, the viruses could be transmitted only by their vectors (e.g., PLRV, aphid transmitted; RSV, leafhopper transmitted; TYLCV, whitefly transmitted); thus, all tests were performed using insect-mediated transmission (Hayakawa et al., 1992; Kawchuk et al., 1990; Kunick et al., 1994; van der Wilk et al., 1991). In most experiments where comparisons were made between aphid transmission and rub inoculation, the lines that were resistant to rub inoculation also were resistant to aphid inocula- 
Table 4. Viral coat protein-mediated resistance to inoculation by natural vectors.

\begin{tabular}{|c|c|c|c|c|}
\hline \multirow[b]{2}{*}{ Virus $^{2}$} & \multirow[b]{2}{*}{ Vector } & \multicolumn{2}{|c|}{ Protection against } & \multirow[b]{2}{*}{ Reference } \\
\hline & & $\begin{array}{c}\text { Rub } \\
\text { inoculation }\end{array}$ & $\begin{array}{l}\text { Vector } \\
\text { inoculation }\end{array}$ & \\
\hline$\overline{\mathrm{RSV}}$ & Planthopper & Not tested ${ }^{y}$ & Protected & Hayakawa et al., 1992 \\
\hline PLRV & Aphid & Not tested ${ }^{y}$ & Protected & $\begin{array}{l}\text { Kawchuk et al., } 1990 \\
\text { van der Wilk et al., } 1991\end{array}$ \\
\hline TYLCV & Whitefly & Not tested $y$ & Protected & Kunik et al., 1994 \\
\hline CMV & Aphid & Protected & Protected & $\begin{array}{l}\text { Quemada et al., } 1991 \\
\text { Gonsalves et al., } 1992\end{array}$ \\
\hline $\begin{array}{l}\text { PVX, } \\
\text { PVY } \\
\text { TRV }\end{array}$ & $\begin{array}{l}\text { Aphid } \\
\text { Nematode }\end{array}$ & $\begin{array}{l}\text { Protected } \\
\text { Protected }\end{array}$ & $\begin{array}{l}\text { Protected } \\
\text { Not protected }\end{array}$ & $\begin{array}{l}\text { Lawson et al., } 1990 \\
\text { Ploeg et al., } 1993\end{array}$ \\
\hline
\end{tabular}

${ }^{2}$ See Table 3 for complete virus names.

${ }^{y}$ Virus is not transmitted by rub inoculation.

tion (CMV: Gonsalves et al., 1992; Quemada et al., 1991) [PVX, potato virus Y (PVY): Lawson et al., 1990]. In contrast to these insecttransmitted viruses, the $\mathrm{CP}$ of tobacco rattle virus conferred protection against rub inoculation, but not against nematode transmission (Ploeg et al., 1993). Ploeg et al. (1993) suggest that protection against nematode transmission fails because the nematodes inject more virus particles into a cell than is normally achieved by manual inoculation.

As with naturally occurring virus resistance genes, strain specificity is an important question, and different genes (be they engineered or naturally occurring) vary in their specificity. As a general rule, the plants were best protected against the virus (or strain) from which the $\mathrm{CP}$ gene was derived, but in many cases, the transgenic plants also were protected against additional virus strains, related heterologous viruses, or both. The CP gene of ZYMV-Ct conferred protection against a variety of other ZYMV strains and the closely related potyvirus WMV, but not against the less closely related papaya ringspot virus (Grumet et al., 1994). Namba et al. (1991), Nejidat and Beachy (1990), Pang et al. (1992), and van Dun and Bol (1988) observed a correlation between the extent of protection and the relatedness between the challenge virus and the virus from which the $\mathrm{CP}$ gene was derived.

There are also, however, some surprising results. The $\mathrm{CP}$ gene of the potyvirus lettuce mosaic virus (LMV) conferred complete protection against the heterologous virus PVY (66\% amino acid homology to LMV), but did not protect against tobacco etch virus, which has a similar percent amino acid homology (Dinant et al., 1993). Interestingly, Murray et al. (1993) reported that corn plants expressing the CP gene of the maize dwarf mosaic virus (MDMV) potyvirus were not only protected against MDMV, but also showed reduced symptom severity when inoculated with maize chlorotic mottle virus (MCMV), a member of the carmovirus group. In fact, when plants were inoculated with a mixture of MDMV and MCMV, they were better protected than when inoculated with MCMV alone.

In summary, CP-mediated protection has been successfully applied to a variety of plant viruses and, in many cases, related strains or viruses. Since CP-mediated protection is the strategy that has been most widely used to date, virtually all of the field trials with virusresistant transgenic plants have used $\mathrm{CP}$-expressing plants. A discussion of the field trial results will be presented in a later section.

\section{Resistance mediated by other viral genes}

Several other types of viral genes have conferred resistance, including replicase genes, movement protein genes, and protease genes (Table 5). The use of viral-encoded replicase genes appears to be promising. As for CP-mediated resistance, replicase-mediated resistance was first demonstrated with TMV (Golemboski et al., 1990). In this case, however, the resistance was inadvertent. These researchers sought to determine the function of a putative $54-\mathrm{kDa}$ protein encoded within the replicase gene and discovered that the 54$\mathrm{kDa}$-expressing transgenic plants were completely resistant to TMV infection, even at inoculum levels up to 1000 -fold higher than conferred by the TMV CP gene. Replicase-mediated protection also has been demonstrated for viruses representing four additional virus
Table 5. Genetically engineered plant virus resistance using nonstructural viral protein genes.

\begin{tabular}{|c|c|c|c|}
\hline Virus group & Virus $^{2}$ & Host species & Reference \\
\hline \multicolumn{4}{|l|}{ Replicase } \\
\hline Cucumovirus & CMV & Tobacco & Anderson et al., 1992 \\
\hline Potexvirus & PVX & Tobacco & Braun and Hemenway, 1992 \\
\hline & & Tobacco & Longstaff et al., 1993 \\
\hline Potyvirus & PVY & Tobacco & Audy et al., 1994 \\
\hline Tobamovirus & TMV & $\begin{array}{l}\text { Tobacco } \\
\text { Tobacco }\end{array}$ & $\begin{array}{l}\text { Golemboski et al., } 1990 \\
\text { Donson et al., } 1993\end{array}$ \\
\hline Tobravirus & $\mathrm{PEBV}^{z}$ & $\begin{array}{l}\text { Nicotiana } \\
\text { benthamiana }\end{array}$ & MacFarlane and Davies, 1992 \\
\hline Tombusvirus & $\mathrm{CyRSV}^{\mathrm{z}}$ & N. benthamiana & Rubino et al., 1993 \\
\hline $\begin{array}{l}\text { Movement protein } \\
\text { Tobamovirus }\end{array}$ & & & \\
\hline Tobamovirus & TMV & Tobacco & Malyshenko et al., 1993 \\
\hline Protease & & & \\
\hline Potyvirus & PVY & Tobacco & Vardi et al., 1993 \\
\hline
\end{tabular}

${ }^{2} \mathrm{PEBV}=$ pea early browning virus, $\mathrm{CyRSV}=$ cymbidium ringspot virus. See Table 3 for complete names of other viruses.

groups: potexviruses (Braun and Hemenway, 1992; Longstaff et al., 1993), tobraviruses (MacFarlane and Davies, 1992), cucumoviruses (Anderson et al., 1992), and tombusviruses (Rubino et al., 1993). As with CP-mediated resistance, in most cases, the level of resistance varied among different transgenic lines, but, in several examples, the level of resistance observed in the most resistant replicase-expressing line was greater than that for the CP-expressing lines (Anderson et al., 1992; Braun and Hemenway, 1992; MacFarlane and Davies, 1992). To my knowledge, reports of testing replicase-expressing plants in the field have not been published.

Two newly demonstrated approaches to pathogen-derived resistance use viral movement proteins or protease genes. Cell-to-cell transport of viruses can involve a viral-encoded movement protein (MP) that interacts with the plasmodesmata to increase the macromolecular exclusion limit and facilitate viral spread to adjacent cells (Deom et al., 1992; Wolf et al., 1989). When tobacco plants were transformed with a defective MP from a TMV mutant, or with the MP from brome mosaic virus, which cannot spread through a tobacco plant, the transgenic plants were protected against infection by TMV (Malyshenko et al., 1993). Presumably, presence of the defective or nonspecies appropriate MP before viral inoculation limited the ability of the incoming functional viral MP to successfully interact with the plasmodesmata.

Another critical step in the life cycle of many viruses is proteolytic processing of viral-encoded proteins. An extreme example is the potyvirus group. The potyvirus genome codes for a single, large polyprotein that is subsequently cleaved into individual mature viral proteins through the action of three viral-encoded proteases (Dougherty and Carrington, 1988). The NIa protein, which performs the majority of cleavages, was used to transform tobacco (Vardi et al., 1993). Unexpectedly, two of 50 transgenic PVY NIa lines were resistant to PVY. In this case, the reason for resistance is unclear; the authors suggest that possible inadvertent alterations occurring during the cloning process may have resulted in a counterfunctional protein.

\section{Antisense and sense-defective RNAs}

Genetically engineered virus resistance also has been accomplished using genes that express RNA but not protein (Table 6). In these examples, antisense (the noncoding strand of RNA) and sensedefective (the coding strand with an alteration that makes it nontranslatable) viral-derived RNA sequences have been used. Presumably, interaction between complementary transgene- and viralencoded sequences interferes with translation, replication, or viral nucleic acid stability. Different types of sequences have been tested, including $3^{\prime}$ and $5^{\prime}$ noncoding regions that include viral regulatory, replication, and translation initiation sites, and coding regions of coat protein and replicase genes. In general, the RNA-mediated protection has been less effective than CP-mediated protection, as was observed for the sense and antisense ZYMV CP genes (Fang and Grumet, 1993). There are, however, notable exceptions, especially in the potyvirus and luteovirus groups where RNA-mediated protection seemed effec- 
Table 6. Genetically engineered plant virus resistance using viral-derived RNA sequences.

\begin{tabular}{|c|c|c|c|}
\hline Virus group & Virus $^{z}$ & Host species & Reference \\
\hline \multicolumn{4}{|l|}{ Antisense } \\
\hline Cucumovirus & CMV & Tobacco & Cuozzo et al., 1988 \\
\hline Geminivirus & TGMV $^{z}$ & Tobacco & Day et al., 1991 \\
\hline Luteovirus & PLRV & Potato & Kawchuk et al., 1991 \\
\hline Potexvirus & PVX & Tobacco & Hemenway et al., 1988 \\
\hline \multirow[t]{4}{*}{ Potyvirus } & BYMV & $\begin{array}{l}\text { Nicotiana } \\
\text { benthamiana }\end{array}$ & Hammond and Kamo, 1993 \\
\hline & PVY & Tobacco & van der Vlugt et al., 1992 \\
\hline & $\mathrm{TEV}^{\mathrm{z}}$ & Tobacco & Lindbo and Dougherty, 1992a \\
\hline & ZYMV & Melon, tobacco & Fang and Grumet, 1993 \\
\hline Tobamovirus & TMV & Tobacco & Powell et al., 1989 \\
\hline Tospovirus & $\mathrm{TSWV}^{\mathrm{z}}$ & Tobacco & Pang et al., 1992 \\
\hline \multicolumn{4}{|l|}{$\begin{array}{c}\text { Sense-defective/ } \\
\text { nontranslated }\end{array}$} \\
\hline Potyvirus & TEV & Tobacco & Lindbo and Dougherty, 1992b \\
\hline Tobamovirus & TMV & Tobacco & Nelson et al., 1993 \\
\hline \multirow[t]{2}{*}{ Tospovirus } & TSWV & Tobacco & de Haan et al., 1992 \\
\hline & & Tobacco & Pang et al., 1992 \\
\hline Tymovirus & TYMV & Rapeseed & Zaccomer et al., 1993 \\
\hline
\end{tabular}

${ }^{\text {zTGMV }}=$ tomato golden mosaic virus, TEV $=$ tobacco etch virus, TSWV $=$ tomato spotted wilt virus, TYMV = turnip yellow mosaic virus. See Table 3 for complete names of other viruses.

tive (Hammond and Kamo, 1993; Kawchuk et al., 1991; Lindbo and Dougherty, 1992a, 1992b). Thus, in some cases, RNA-mediated protection may prove a useful strategy for engineering resistance.

\section{Viral parasites}

Interestingly, despite their extreme simplicity and complete dependence on the host cell for all metabolic activity, several groups of viruses can acquire accompanying nucleic acid sequences that may be viewed as molecular parasites (Francki, 1985). These sequences, which include satellites and defective interfering particles (DIs), are not essential for virus function and can suppress symptom development, multiplication of the helper virus, or both (Collmer and Howell, 1992; Roosnick et al., 1992; Roux et al., 1991). As such, they have become candidate sequences for genetically engineering virus resistance. Examples to date have centered around the satellites of CMV and tobacco ringspot virus, and the DIs of African cassava mosaic virus, beet curly top virus, and cymbidium ringspot virus (Table 7; see references cited there). Transgenic plants have been engineered to express the satellite or DI sequences; upon challenge inoculation by the helper virus, the transgene-expressed sequences become amplified by the viral replication machinery. The inoculated leaves become infected in most cases, but leaves developing later are protected from severe symptom development. The degree of protection is insensitive to inoculum concentration and independent of the level of expression of transgene-derived sequences (Harrison et al., 1987; Jacquemond et al., 1988). Protection conferred by CMV satRNA was effective against

Table 7. Genetically engineered plant virus resistance using viral parasites.

\begin{tabular}{|c|c|c|c|}
\hline Virus group & Virus $^{2}$ & Host species & Reference \\
\hline \multicolumn{4}{|l|}{ Satellite } \\
\hline \multirow[t]{5}{*}{ Cucumovirus } & CMV & Tobacco & Harrison et al., 1987 \\
\hline & & Tobacco & Jaquemond et al., 1988 \\
\hline & & Tobacco & Yie et al., 1992 \\
\hline & & Tomato & Saito et al., 1992 \\
\hline & & Tomato & McGarvey et al., 1994 \\
\hline Nepovirus & TobRV $^{z}$ & Tobacco & Gerlach et al., 1987 \\
\hline \multicolumn{4}{|l|}{$\begin{array}{l}\text { Defective- } \\
\text { interfering }\end{array}$} \\
\hline \multirow[t]{2}{*}{ Geminivirus } & $\mathrm{ACMV}^{2}$ & $\begin{array}{l}\text { Nicotiana } \\
\text { benthamiana }\end{array}$ & Stanley et al., 1990 \\
\hline & $\mathrm{BCTV}^{\mathrm{z}}$ & N. benthamiana & Frischmuth and Stanley, 1994 \\
\hline Tombusvirus & CyRSV & N. benthamiana & Kollar et al., 1993 \\
\hline
\end{tabular}

${ }^{2} \mathrm{TobRV}=$ tobacco ringspot virus, ACMV = African cassava mosaic virus, $\mathrm{BCTV}=$ beet curly top virus. See Tables 3 and 5 for complete names of other viruses. aphid transmission as well as rub inoculation (Jacquemond et al., 1988). After inoculation, the amplified transgene-derived sequences become encapsidated in the helper virus $\mathrm{CP}$ and are transmitted in subsequent passages along with the helper virus (Gerlach et al., 1987; Harrison et al., 1987; Stanley et al., 1990). Although only a limited number of viruses have satellites or DIs, this approach, where available, seems effective. Other researchers are investigating the possibility of creating artificial DIs for viruses that do not have them naturally (e.g., Huntley and Hall, 1993; Marsh et al., 1991). However, because satellites and DIs are replicating entities with a complex biology, several concerns exist about the ecological safety of this approach (e.g., Tepfer, 1993). These concerns have detracted from testing satellite- or DI-expressing plants in the field.

\section{FIELD PERFORMANCE}

Ultimately, if we are to use these strategies to develop virusresistant cultivars, the materials must perform well in the field not only with regard to general crop growth and yield, but also in response to virus infection. A frequently asked question is what effects do regeneration, transformation, and expression of the viral gene per se have on crop performance? In respect to regeneration and transformation, plants possibly might be affected by somaclonal variation or by the site of integration of the transgenes. As might be expected, in a study comparing field performance of various potato lines, those derived from regenerated or transgenic plants were more variable than those from tuber nodal shoot cuttings (Dale and McPartlan, 1992). In a study comparing field performance of transgenic potato lines expressing PVX CP with their nontransgenic counterparts, the degree of variation was genotype dependent (Hoekema et al., 1989; Jongedijk et al., 1992). Even though somaclonal variation occurred, several lines were obtained that retained their agronomic or horticultural qualities. Clearly, there are possible effects of the transformation and regeneration processes that should be screened for during early testing.

Another concern is the effect of viral gene expression. With the exception of examples of the introduction of $\mathrm{CP}$ genes from necrosisinducing TMV or tomato mosaic virus (ToMV) strains into hypersensitive Nicotiana genotypes (Culver and Dawson, 1991; Pfitzner and Pfitzner, 1992), transgenic plants expressing viral sequences have appeared phenotypically normal. The sequences per se, even those of satellites or DIs, did not cause any symptom development. In experiments comparing the yield of noninoculated transgenic and control plants, there was no difference between transgenic TMV CP-expressing tomato plants, or between PVX CP- and PVY CP-expressing potato plants, and their respective nontransgenic controls (Kaniewski et al., 1990; Sanders et al., 1992). Thus, CP gene(s) did not appear to have a negative effect.

The majority of experiments testing virus resistance in the field have been performed by industry personnel; they requested $\approx 75 \%$ of the U.S. Dept. of Agriculture permits issued from 1987 to 1993 for transgenic plants expressing viral genes. Although only a few field trial studies have been published, those that have, have been encouraging. The percentage of infection for transgenic tomato plants expressing TMV or ToMV CP genes was significantly lower than for nontransgenic controls (Nelson et al., 1988; Sanders et al., 1992). In two trials, the inoculated control plants exhibited yield losses of $35 \%$ and $69 \%$, while yield of the inoculated transgenic plants was not reduced. Similarly, the yield of a control potato line infected with PVX and PVY was reduced by $28 \%$, while a transgenic potato line expressing PVX and PVY CP genes was free of symptoms and did not suffer yield loss (Kaniewski et al., 1990). Jongedijk et al. (1992) observed that PVX CP-expressing potato plants had fewer infected seed tubers. In an experiment with natural aphid-mediated spread of CMV, transgenic CMV CP-expressing cucumber plants had significantly less viral infection relative to nontransgenic, susceptible controls (Gonsalves et al., 1992).

Another question that is asked frequently regarding engineered virus resistance concerns the long-term stability of this approach. This is potentially an important issue for both naturally occurring and engineered resistance genes. Virus evolution can, and has, resulted in strains that can overcome host-derived resistance genes (Fraser, 1990); 
this is likely to be the case for engineered resistance as well. Although the occurrence of specific strains overcoming CP-mediated resistance has not been reported yet, it is too soon to draw any conclusions. All trials to date have been in experimental plots; we do not currently have the large-scale agricultural plantings that will ultimately test the usefulness and longevity of the genes. There is an interesting example, however, of a mutant strain of pea early browning virus that arose in laboratory tests and was able to overcome replicase-mediated protection (MacFarlane and Davies, 1992). In my opinion, however, the possibility of viral strains that are capable of overcoming resistance should not preclude the development of these types of resistance strategies. We should, however, view these genetically engineered resistance genes as potential components of a broader-based program to develop virus-resistant cultivars.

In summary, substantial progress has been made in the past decade toward genetically engineering virus-resistant crops. As more genes, viruses, and hosts are used, we should see increasing numbers of horticultural crops that have been engineered for virus resistance.

\section{Literature Cited}

Anderson, J.M., P. Palukaitis, and M. Zaitlin. 1992. A defective replicase gene induces resistance to cucumber mosaic virus in transgenic tobacco plants. Proc. Natl. Acad. Sci. USA 89:8759-8763.

Audy, P., P. Palukaitis, S.A. Slack, and M. Zaitlin. 1994. Replicase-mediated resistance to potato virus $\mathrm{Y}$ in transgenic tobacco plants. Mol. PlantMicrobe Interact. 7:15-22.

Barker, H., B. Reavy, A. Kumar, K.D. Webster, and M.A. Mayo. 1992. Restricted virus multiplication in potatoes transformed with the coat protein gene of potato leafroll luteovirus: Similarities with a type of host gene-mediated resistance. Ann. Appl. Biol. 120:55-64.

Beachy, R.N., S. Loesch-Fries, and N.E. Tumer. 1990. Coat protein-mediated resistance against virus infection. Annu. Rev. Phytopathol. 28:451-474.

Bertioli, D.J., J.I. Cooper, M.L. Edwards, and W.S. Hawes. 1992. Arabis mosaic nepovirus coat protein in transgenic tobacco lessens disease severity and virus replication. Ann. Appl. Biol. 120:47-54.

Brault, V., T. Candresse, O. le Gall, R.P. Delbos, M. Lanneau, and J. Dunez. 1993. Genetically engineered resistance against grapevine chrome mosaic nepovirus. Plant Mol. Biol. 21:89-97.

Braun, C.J. and C.L. Hemenway. 1992. Expression of amino-terminal portions or full-length viral replicase genes in transgenic plants confers resistance to potato virus X infection. Plant Cell 4:735-744.

Chia, T.F., Y.S. Chan, and N.H. Chua. 1992. Characterization of cymbidium mosaic virus coat protein gene and its expression in transgenic tobacco plants. Plant Mol. Biol. 18:1091-1099.

Collmer, C.W. and S.H. Howell. 1992. Role of satellite RNA in the expression of symptoms caused by plant viruses. Annu. Rev. Phytopathol. 30:419442.

Culver, J.N. and W.O. Dawson. 1991. Tobacco mosaic virus elicitor coat protein genes produce a hypersensitive phenotype in transgenic Nicotiana sylvestris plants. Mol. Plant-Microbe Interact. 5:458-463.

Cuozzo, M., K.M. O'Connell, W. Kaniewski, R.-X. Fang, N.-H. Chua, and N.E. Tumer. 1988. Viral protection in transgenic tobacco plants expressing the cucumber mosaic virus coat protein or its antisense RNA. Bio/Technology 6:549-557.

Dale, P.J. and H.C. McPartlan. 1992. Field performance of transgenic potato plants compared with controls regenerated from tuber discs and shoot cuttings. Theor. Appl. Genet. 84:585-591.

Day, A.G., E.R. Bejarano, K.W. Buck, M. Burrell, and C.P. Lichtenstein. 1991. Expression of an antisense viral gene in transgenic tobacco confers resistance to the DNA virus tomato golden mosaic virus. Proc. Natl. Acad. Sci. USA 88:6721-6725.

de Haan, P., J.J.L. Gielen, M. Prins, I.G. Wijkamp, A. van Schepen, D. Peters, M.Q.J.M. van Grinsven, and R. Goldbach. 1992. Characterization of RNAmediated resistance to tomato spotted wilt virus in transgenic tobacco plants. Bio/Technology 10:1133-1138.

Deom, C.M., M. Lapidot, and R.N. Beachy. 1992. Plant virus movement proteins. Cell 69:221-224.

Dinant, S., F. Blaise, C. Kusiak, S. Astier-Manifacier, and J. Albouy. 1993. Heterologous resistance to potato virus $\mathrm{Y}$ in transgenic tobacco plants expressing the coat protein gene of lettuce mosaic potyvirus. Phytopathology 83:818-824.

Donson, J., C.M. Kearny, T.H. Turpen, I.A. Khan, G. Kurath, A.M. Turpen, G.E. Jones, W.O. Dawson, and D.J. Lewandowski. 1993. Broad resistance to tobamoviruses is mediated by a modified tobacco mosaic virus replicase transgene. Mol. Plant-Microbe Interact. 6:635-642.

Dougherty, W.G. and J.C. Carrington. 1988. Expression and function of potyviral gene products. Annu. Rev. Phytopathol. 26:123-143

Fang, G. and R. Grumet. 1993. Genetic engineering of potyvirus resistance using constructs derived from the zucchini yellow mosaic virus coat protein gene. Mol. Plant-Microbe Interact. 6:358-367.

Fitch, M.M.M., R.M. Manshardt, D. Gonsalves, J.L. Slightom, and J.C. Sanford. 1992. Virus resistant papaya plants derived from tissues bombarded with the coat protein gene of papaya ringspot virus. Bio/Technology 10:1466-1472.

Fitchen, J.H. and R.N. Beachy. 1993. Genetically engineered protection against viruses in transgenic plants. Annu. Rev. Microbiol. 47:739-763.

Francki, R.I.B. 1985. Plant virus satellites. Annu. Rev. Microbiol. 39:151-174.

Fraser, R.S.S. 1990. The genetics of resistance to plant viruses. Annu. Rev. Phytopathol. 28:179-200.

Frischmuth, T. and J. Stanley. 1994. Beet curly top virus symptom amelioration in Nicotiana benthamiana transformed with a naturally occurring viral subgenomic DNA. Virology 200:826-830.

Gadani,F., L.M. Mansky, R. Medici, W.A. Miller, and J.H. Hull. 1990. Genetic engineering of plants for virus resistance. Arch. Virol. 115:1-21.

Gasser, C.S. and R.T. Fraley. 1989. Genetically engineering of plants for crop improvement. Science 244:1293-1299.

Gerlach, W.L., D. Llewellyn, and J. Haseloff. 1987. Construction of a plant disease resistance gene from the satellite RNA of tobacco ringspot virus. Nature 328:802-805.

Gielen, J.J.L., P. de Haan, A.J. Kool, D. Peters, M.Q.J.M. van Grinsven, and R.W. Goldbach. 1991. Engineered resistance to tomato spotted wilt virus, a negative-strand RNA virus. Bio/Technology 9:1363-1367.

Golemboski, D.B., G.P. Lomonossoff, and M. Zaitlin. 1990. Plants transformed with a tobacco mosaic virus nonstructural gene sequence are resistant to the virus. Proc. Natl. Acad. Sci. USA 87:6311-6315.

Gonsalves, C., B. Xue, M. Yepes, M. Fuchs, K. Ling, S. Namba, P. Chee, J.L. Slightom, and D. Gonsalves. 1994. Transferring cucumber mosaic viruswhite leaf strain coat protein gene into Cucumis melo L. and evaluating transgenic plants for protection against infection. J. Amer. Soc. Hort. Sci. 119:345-355.

Gonsalves, D., P. Chee, R. Provvidenti, R. Seem, and J.L. Slightom. 1992. Comparison of coat protein-mediated and genetically-derived resistance in cucumbers to infection by cucumber mosaic virus under field conditions with natural challenge inoculations by vectors. Bio/Technology 10:15621570 .

Grumet, R. 1990. Genetically engineered plant virus resistance. HortScience 25:508-513.

Grumet, R. 1994. Development of virus resistant plants via genetic engineering. Plant Breeding Rev. 12:47-79.

Grumet, R., R.C. Yadav, G. Akula, S. Hammar, and R. Provvidenti. 1995. Genetic engineering of virus resistance in cucurbit crops. Proc. Cucurbitaceae '94. (In press.)

Hammond, J. and K.K. Kamo. 1993. Transgenic coat protein and antisense RNA resistance to bean yellow mosaic potyvirus. Acta Hort. 336:171-178.

Harrison, B.D., M.A. Mayo, and D.C. Baulcombe. 1987. Virus resistance in transgenic plants that express cucumber mosaic virus satellite RNA. Nature (London) 328:799-802.

Hayakawa, T., Y. Zhu, K. Itoh, Y. Kimura, T. Izawa, K. Shimamoto, and S. Toriyama. 1992. Genetically engineered rice resistant to rice stripe virus, an insect-transmitted virus. Proc. Natl. Acad. Sci. USA 89:9865-9869.

Hemenway, C., R.-X. Fang, W.K. Kaniewski, N.-H. Chua, and N.E. Tumer. 1988. Analysis of the mechanism of protection in transgenic plants expressing the potato virus $X$ coat protein or its antisense RNA. EMBO J. 7:12731280 .

Hill, K.K., N. Jarvis-Eagan, E.L. Halk, K.J. Krahn, L.W.Liao, R.S. Mathewson, D.J. Merlo, S.E. Nelson, K.E. Rashka, and L.S. Loesch-Fries. 1991. The development of virus-resistant alfalfa, Medicago sativa $\mathrm{L}$. Bio/Technology 9:373-377.

Hoekema, A., M.J. Huisman, L. Molendijk, P.J.M. van den Elzen, and B.J.C. Cornelissen. 1989. The genetic engineering of two commercial potato cultivars for resistance to potato virus X. Bio/Technology 7:273-278.

Hull, R. and J.W. Davies. 1992. Approaches to nonconventional control of plant virus diseases. Crit. Rev. Plant Sci. 11:17-33.

Huntley, C.C. and T.C. Hall. 1993. Minus sense transcripts of brome mosaic virus RNA-3 intercistronic region interfere with viral replication. Virology 192:290-297.

Jacquemond, L., J. Amselem, and M. Tepfer. 1988. Gene coding for a monomeric form of cucumber mosaic virus satellite RNA confers tolerance to CMV. Mol. Plant-Microbe Interact. 1:311-316.

Jongedijk, E., A.A.J.M. de Schutter, T. Stolte, P.J.M. van den Elzen, and B.J.C. Cornelissen. 1992. Increased resistance to potato virus $\mathrm{X}$ and preservation of cultivar properties in transgenic potato under field conditions. Bio/ Technology 10:422-429.

Kaniewski, W., C. Lawson, B. Sammons, L. Haley, J. Hart, X. Delannay, and N.E. Tumer. 1990. Field resistance of transgenic Russet Burbank potato to 
effects of infection by potato virus $\mathrm{X}$ and potato virus $\mathrm{Y}$. Bio/Technology 8:750-754.

Kawchuk, L.M., R.R. Martin, and J. McPherson. 1990. Resistance in transgenic potato expressing the potato leafroll virus coat protein gene. Mol. PlantMicrobe Interact. 3:301-307.

Kawchuk, L.M., R.R. Martin, and J. McPherson. 1991. Sense and antisense RNA-mediated resistance to potato leafroll virus in Russet Burbank potato plants. Mol. Plant-Microbe Interact. 4:247-253.

Kollar, A., T. Dalmay, and J. Burgyan. 1993. Defective interfering RNAmediated resistance against cymbidium ringspot virus in transgenic plants. Virology 193:313-318.

Knott, D.R. and J. Dvorak. 1976. Alien germplasm as a source of resistance to disease. Annu. Rev. Phytopathol. 14:211-235.

Kunik, T., R. Salomon, D. Zamir, N. Navot, M. Zeidan, I. Michelson, Y. Gafni, and H. Czosnek. 1994. Transgenic tomato plants expressing the tomato yellow leaf curl virus capsid protein are resistant to the virus. Bio/ Technology 12:500-504.

Kyle, M.M. 1993. Resistance to viral diseases of vegetables: Genetics and breeding. Timber Press, Portland, Ore.

Lawson, C., W. Kaniewski, L. Haley, R. Rozman, C. Newell, P. Sanders, and N.E. Tumer. 1990. Engineering resistance to mixed virus infection in a commercial potato cultivar: Resistance to potato virus $\mathrm{X}$ and potato virus $\mathrm{Y}$ in transgenic Russet Burbank. Bio/Technology 8:127-134.

Lindbo, J.A. and W.G. Dougherty. 1992a. Pathogen-derived resistance to a potyvirus: Immune and resistant phenotypes in transgenic tobacco expressing altered forms of a potyvirus coat protein nucleotide sequence. Mol. Plant-Microbe Interact. 5:144-153.

Lindbo, J.A. and W.G. Dougherty. 1992b. Untranslatable transcripts of the tobacco etch virus coat protein gene sequence can interfere with tobacco etch virus replication in transgenic plants and protoplasts. Virology 189:725733.

Ling, K., S. Namba, C. Gonsalves, J.L. Slightom, and D. Gonsalves. 1991. Protection against detrimental effects of potyvirus infection in transgenic tobacco plants expressing the papaya ringspot virus coat protein gene. Bio/ Technology 9:752-758.

Loesch-Fries, L.S., D. Merlo, T. Zinnen, L. Burhop, K. Hill, K. Krahn, N. Jarvis, S. Nelson, and E. Halk. 1987. Expression of alfalfa mosaic virus RNA 4 in transgenic plants confers virus resistance. EMBO J. 6:18451851.

Longstaff, M., G. Brigneti, F. Boccard, S. Chapman, and D. Baulcombe. 1993. Extreme resistance to potato virus $\mathrm{X}$ infection in plants expressing a modified component of the putative viral replicase. EMBO J. 12:379-386.

MacFarlane, S.A. and J.W. Davies. 1992. Plants transformed with a region of the 201-kilodalton replicase gene from pea early browning virus RNA1 are resistant to virus infection. Proc. Natl. Acad. Sci. USA 89:5829-5833.

MacKenzie, D.J. and P.J. Ellis. 1992. Resistance to tomato spotted wilt virus infection in transgenic tobacco expressing the viral nucleocapsid gene. Mol. Plant-Microbe Interact. 5:34-40.

MacKenzie, D.J. and J.H. Tremaine. 1990. Transgenic Nicotiana debneyii expressing viral coat protein are resistant to potato virus $\mathrm{S}$ infection. J. Gen. Virol. 71:2167-2170

MacKenzie, D.J., J.H. Tremaine, and J. McPherson. 1991. Genetically engineered resistance to potato virus $\mathrm{S}$ in potato cultivar Russet Burbank. Mol. Plant-Microbe Interact. 4:95-102.

Malyshenko, S.I., O.A. Kondakova, J.V.Nazarova, I.B. Kaplan, M.E. Taliansky, and J.G. Atabekov. 1993. Reduction of tobacco mosaic virus accumulation in transgenic plants producing non-functional viral transport proteins. J. Gen. Virol. 74:1149-1156.

Marsh, L.E., G.P. Pogue, J.P. Connell, and T.C. Hall. 1991. Artificial defective interfering RNAs derived from brome mosaic virus. J. Gen. Virol. 72:17871792.

McGarvey, P.B., M.S. Montasser, and J.M. Kaper. 1994. Transgenic tomato plants expressing satRNA are tolerant to some strains of cucumber mosaic virus. J. Amer. Soc. Hort. Sci. 119:642-647.

Murray, L.E., L.G. Elliott, S.A. Capitant, J.A. West, K.K. Hanson, L. Scarafia, S. Johnston, C. DeLuca-Flaherty, S. Nichols, D. Cunanan, P.S. Dietrich, I.J. Mettler, S. Dewald, D.A. Warnick, C. Rhodes, R.M. Sinibaldi, and K.J. Brunke. 1993. Transgenic corn plants expressing MDMV strain B coat protein are resistant to infections of maize dwarf mosaic virus and maize chlorotic mottle virus. Bio/Technology 11:1559-1564.

Nakajima, M., T. Hayakawa, I. Nakamura, and M. Suzuki. 1993. Protection against cucumber mosaic virus (CMV) strains $\mathrm{O}$ and $\mathrm{Y}$ and chrysanthemum mild mottle virus in transgenic tobacco plants expressing CMV-O coat protein. J. Gen. Virol. 74:319-322.

Namba, S., K. Ling, C. Gonsalves, D. Gonsalves, and J.L. Slightom. 1991. Expression of the gene encoding the coat protein of cucumber mosaic virus (CMV) strain WL appears to provide protection to tobacco plants against infection by several different CMV strains. Gene 107:181-188.

Namba, S., K. Ling, C. Gonsalves, J.L. Slightom, and D. Gonsalves. 1992.
Protection of transgenic plants expressing the coat protein gene of watermelon mosaic virus II or zucchini yellow mosaic virus against six potyviruses. Phytopathology 82:940-946.

Nejidat, A. and R.N. Beachy. 1989. Decreased levels of TMV coat protein in transgenic tobacco plants at elevated temperatures reduce resistance to TMV infection. Virology 173:531-538.

Nejidat, A. and R.N. Beachy. 1990. Transgenic tobacco plants expressing a coat protein gene of tobacco mosaic virus are resistant to some other tobamoviruses. Mol. Plant-Microbe Interact. 3:247-251.

Nelson, A., D.A. Roth, and J.D. Johnson. 1993. Tobacco mosaic virus infection of transgenic Nicotiana tabacum plants is inhibited by antisense constructs directed at the 5' region of viral RNA. Gene 127:227-232.

Nelson, R.S., S.M. McCormick, X. Delaney, P. Dube, J. Layton, E.J. Anderson, M. Kaniewski, R.K. Proksch, R.B. Horsch, S.G. Rogers, R.T. Fraley, and R.N. Beachy. 1988. Virus tolerance, plant growth, and field performance of transgenic tomato plants expressing coat protein from tobacco mosaic virus. Bio/Technology 6:403-409.

Nelson, R.S., P. Powell, and R.N. Beachy. 1990. Coat protein-mediated protection against virus infection, p. 13-24. In: G.W. Lycett and D. Grierson (eds.). Genetic engineering of crop plants. Butterworths, Borough Green, Sevenoaks, Kent, U.K

Pang, S.-Z., P. Nagpala, M. Wang, J.L. Slightom, and D. Gonsalves. 1992. Resistance to heterologous isolates of tomato spotted wilt virus in transgenic tobacco expressing its nucleocapsid protein gene. Phytopathology 82:1223 1229.

Pfitzner, U.M. and A.J.P. Pfitzner. 1992. Expression of a viral avirulence gene in transgenic plants is sufficient to induce the hypersensitive defense reaction. Mol. Plant-Microbe Interact. 5:318-321.

Ploeg, A.T., A. Mathis, J.F. Bol, D.J.F. Brown, and D.J. Robinson. 1993. Susceptibility of transgenic tobacco plants expressing tobacco rattle virus coat protein to nematode-transmitted and mechanically inoculated tobacco rattle virus. J. Gen. Virol. 74:2709-2715.

Powell, P.A., D.M. Stark, P.R. Sanders, and R.N. Beachy. 1989. Protection against tobacco mosaic virus in transgenic plants that express tobacco mosaic virus antisense RNA. Proc. Natl. Acad. Sci. USA 86:6949-6952.

Powell-Abel, P., R.S. Nelson, B. De, N. Hoffmann, S.G. Rogers, R.T. Fraley, and R.N. Beachy. 1986. Delay of disease development in transgenic plants that express the tobacco mosaic virus coat protein gene. Science 232:738743.

Quemada, H.D., D. Gonsalves, and J.L. Slightom. 1991. Expression of coat protein gene from cucumber mosaic virus strain $\mathrm{C}$ in tobacco: Protection against infection by CMV strain transmitted mechanically or by aphids. Phytopathology 81:794-802.

Regner, F., A. da Camara Machado, M.L. da Camara Machado, H. Steinkellner, D. Mattanovich, V. Hanzer, H. Weiss, and H. Katinger. 1992. Coat protein mediated resistance to plum pox virus in Nicotiana clevelandii and $N$. benthamiana. Plant Cell Rpt. 11:30-33.

Roossinck, M.J., D. Sleat, and P. Palukaitis. 1992. Satellite RNAs of plant viruses: Structures and biological effects. Microbiol. Rev. 56:265-279.

Roux, L., A.E. Simon, and J.J. Holland. 1991. Effects of defective interfering viruses on virus replication and pathogenesis in vitro and in vivo. Adv. Virus Res. 40:181-211.

Rubino, L., R. Lupo, and M. Russo. 1993. Resistance to cymbidium ringspot tombusvirus infection in transgenic Nicotiana benthamiana plants expressing a full-length viral replicase gene. Mol. Plant-Microbe Interact. 6:729734.

Saito, Y., T. Komari, C. Masuta, Y. Hayashi, T. Kumashiro, and Y. Takanami. 1992. Cucumber mosaic virus-tolerant transgenic tomato plants expressing a satellite RNA. Theor. Appl. Genet. 83:679-683.

Sanders, P.R., B. Sammons, W. Kaniewski, L. Haley, J. Layton, B.J. LaVallee, X. Delannay, and N.E. Tumer. 1992. Field resistance of transgenic tomatoes expressing the tobacco mosaic virus or tomato mosaic virus coat protein genes. Phytopathology 82:683-690.

Sanford, J.C. and S.A. Johnston. 1985. The concept of parasite derived resistance-Deriving resistance genes from the parasite's own genome. J. Theor. Biol. 113:395-405.

Scholthof, K-B.G., H.B. Scholthof, and A.O. Jackson. 1993. Control of plant virus diseases by pathogen-derived resistance in transgenic plants. Plant Physiol. 102:7-12

Stanley, J., T. Frischmuth, and S. Ellwood. 1990. Defective DNA ameliorates symptoms of geminivirus infection in transgenic plants. Proc. Natl. Acad. Sci. USA 87:6291-6295.

Stark, D.M. and R.N. Beachy. 1989. Protection against potyvirus infection in transgenic plants: Evidence for broad spectrum resistance. Bio/Technology 7:1257-1262.

Tavladoraki, P., E. Benvenuto, S. Trinca, D. De Martinis, A. Cattaneo, and P. Galeffi. 1993. Transgenic plants expressing a functional single-chain antibody are specifically protected from virus attack. Nature (London) 366:469-472. 
Tepfer, M. 1993. Viral genes and transgenic plants. What are potential environmental risks? Bio/Technology 11:1125-1132.

Truve, E., A. Aaspollu, J. Honkanen, R. Puska, M. Mehto, A. Hassi, T.H. Teeri, M. Kelve, P. Seppanen, and M. Saarma. 1993. Transgenic potato plants expressing mammalian 2'-5' oligoadenylate synthetase are protected from potato virus X infection under field conditions. Bio/Technology 11:10481051.

Tumer, N.E., K.M. O'Connell, R.S. Nelson, P.R. Sanders, R.N. Beachy, R.T. Fraley, and D.M. Shah. 1987. Expression of alfalfa mosaic virus coat protein gene confers cross-protection in transgenic tobacco and tomato plants. EMBO J. 6:1181-1188.

van der Vlugt, R.A.A., R.K. Ruiter, and R. Goldbach. 1992. Evidence for sense RNA-mediated protection to PVY ${ }^{\mathrm{N}}$ in tobacco plants transformed with the viral coat protein cistron. Plant Mol. Biol. 20:631-639.

van der Wilk, F., D.P.-L. Willink, M.J. Huisman, H. Huttinga, and R. Goldbach. 1991. Expression of the potato leafroll luteovirus coat protein gene in transgenic potato plants inhibits viral infection. Plant Mol. Biol. 17:431439.

van Dun, C.M.P. and J.F. Bol. 1988. Transgenic tobacco plants accumulating tobacco rattle virus coat protein resist infection with tobacco rattle virus and pea early browning virus. Virology 167:649-652.

van Dun, C.M.P., J.F. Bol, and L. Van Vloten-Doting. 1987. Expression of alfalfa mosaic virus and tobacco rattle virus coat protein genes in transgenic tobacco plants. Virology 159:299-305. van Dun, C.M.P., B. Overduin, L. Van Vloten-Doting, and J.F. Bol. 1988. Transgenic tobacco expressing tobacco streak virus or mutated alfalfa mosaic virus coat protein does not cross protect against alfalfa mosaic virus infection. Virology 164:383-389.

Vardi, E., I. Sela, O. Edelbaum, O. Livneh, L. Kuzentsova, and Y. Stram. 1993. Plants transformed with a cistron of a potato virus Y protease (NIa) are resistant to virus infection. Proc. Natl. Acad. Sci. USA 90:7513-7517.

Wenzel, G. 1985. Strategies in unconventional breeding for disease resistance. Annu. Rev. Phytopathol. 23:149-172.

Wilson, T.M.A. 1993. Strategies to protect crop plants against viruses. Proc. Natl. Acad. Sci. USA 90:3134-3141.

Wolf, S., C.M. Deom, R.N. Beachy, and W.L. Lucas. 1989. Movement protein of tobacco mosaic virus modifies plasmodesmatal size exclusion limit. Science 246:337-339.

Yie, Y., F. Zhao, S.Z. Zhao, Y.Z. Liu, Y.L. Liu, and P. Tien. 1992. High resistance to cucumber mosaic virus conferred by satellite RNA and coat protein in transgenic commercial tobacco cultivar G-140. Mol. PlantMicrobe Interact. 5:460-465.

Zaccomer, B., F. Cellier, J.C. Boyer, A.L. Haenni, and M. Tepfer. 1993. Transgenic plants that express genes including the 3' untranslated region of the turnip yellow mosaic virus (TYMV) genome are partially protected against TYMV infection. Gene 136:87-94.

Zaitlin, M. and R. Hull. 1987. Plant virus-host interactions. Annu. Rev. Plant Physiol. 38:291-315.

\title{
Novel Approaches for Genetic Resistance to Bacterial Pathogens in Flower Crops
}

\author{
Adelheid R. Kuehnle, Fure-Chyi Chen', and Nellie Sugii \\ Department of Horticulture, University of Hawaii, Honolulu, HI 96822
}

Bacterial diseases plague many flower crops. Fortunately, for ornamentals cultivated under glasshouse conditions, bacterial diseases are less prevalent than fungal or viral diseases (Dons et al., 1991). Nevertheless, bacterial diseases can be devastating when an outbreak occurs. The most common causal organisms are from five genera of bacteria: Erwinia, Xanthomonas, Pseudomonas, Clavibacter (Cornybacterium), and Agrobacterium. These bacteria cause the familiar symptoms of leaf spots, blights, rots, wilts, cankers, and galls (Powell and Lindquist, 1992) and affect many of the major cut-flower and flowering potted-plant crops (Table 1). Perhaps one of the best known bacterial diseases among ornamentals is xanthomonas bacterial blight/wilt in geranium. Despite disease control advances made since the 1960 s, before which the geranium market was virtually nonexistent due to the prevalence of bacterial blight/wilt, the disease continues to be a risk for geranium propagators and growers alike (Whealey, 1994). Forced dumping of geranium stock plants due to an outbreak of Xanthomonas even occurred this past year.

Through use of horticultural methods that practice sanitation (Baker, 1957) and pathogen exclusion, bacterial disease problems can be minimized. Sanitation is useless, however, if diseased plants are not first eliminated from the farm. Unfortunately, some growers are still reluctant to do this. Today, culture-indexed cuttings for many cutflower and potted florist crops can be obtained from specialist propagators. Limited chemical controls, such as antibiotics or copper sprays, also can be used on the farm. However, frequent usage results in pathogen resistance (Cooksey, 1990). Moreover, these controls are not curative, and they do not economically solve extensive bacterial disease problems.

\footnotetext{
Received for publication 20 Oct. 1994. Accepted for publication 16 Nov. 1994 Journal Series no. 4007 of the Hawaii Institute of Tropical Agriculture and Human Resources. Research supported in part by the State of Hawaii Governor's Agricultural Coordinating Committee Grant 89-22 and the Hawaiian Anthurium Industry Association. We thank J. Jaynes, A. Alvarez, D. Norman, and D. Coyne for their contributions. The cost of publishing this paper was defrayed in part by the payment of page charges. Under postal regulations, this paper therefore must be hereby marked advertisement solely to indicate this fact.

${ }^{1}$ Former Graduate Research Assistant of A.R. Kuehnle. Current address: National Pingtung Polytechnic Institute, Pingtung 91207, Taiwan.
}

Genetic resistance offers one way to manage disease. When combined with the use of culture-indexed propagules and sanitation, it can be a powerful control. Classical breeding offers some genetic solutions, but little has been published regarding resistance to bacterial diseases of florist crops. This dearth contrasts sharply with the active resistance breeding for other horticultural and agronomic crops and with the progress made in fungal disease resistance in some flowers crops, e.g., Fusarium spp. in carnation and tulip, Puccinia horiana Henn. (white rust) in chrysanthemum, and Colletotrichum gloeosporioides Penz. (anthracnose) in anthurium (Aragaki et al., 1968; Sparnaaij, 1991). Introgression of resistance genes, either through tissue culture manipulations, use of molecular genetics, or by genetic engineering, are supplementary breeding approaches that appear promising. Yet, despite the current and predicted importance of the floriculture industry to U.S. agriculture (1993 wholesale value approached \$3 billion), little use of novel breeding strategies for (bacterial) disease control is evident in either the public or private sector.

In the last several years, numerous papers describing genetic transformation systems for floricultural crops have appeared (Robinson and Firoozabady, 1993). Preceding and during this same period, numerous biological compounds have been identified with potent antimicrobial properties - research driven in part by the biomedical and food science fields. The objective of this paper is to discuss previous and current research that uses novel genetic strategies to control bacterial disease in various cropping systems, with focus on integrating genetic engineering with nonplant resistance genes. A case study for controlling Xanthomonas spp., species of which severely limit geranium and anthurium production, is given for anthurium, using genes derived from those of the Cecropia moth.

\section{Novel approaches: Cloning resistance genes from plants via molecular genetics}

Screening plant extracts for antibacterial activity has identified many potentially useful compounds, but it has seldom led to identification of the associated plant genes. Focusing on plant molecular signals active during early stages of infection has been more successful; many research groups are targeting host genes involved in patho- 
Table 1. Common bacterial diseases of some major cut flowers and flowering potted plants.

\begin{tabular}{lll}
\hline \hline Crop & \multicolumn{1}{c}{ Disease } & \multicolumn{1}{c}{ Pathogen } \\
\hline Anthurium & Blight & Xanthomonas campestris pv. dieffenbachiae \\
Begonia & Leaf spot and blight & Xanthomonas campestris pv. begoniae (Takimoto) Dye \\
Carnation & Bacterial spot and blight & Pseudomonas woodsii (Smith) Stevens \\
& Bacterial wilt & Pseudomonas caryophylli (Burkholder) Starr \& Burkholder \\
Chrysanthemum & Bacterial blight & Erwinia chrysanthemi Burkholder, McFadden \& Dimock \\
& Bacterial leaf spot & Pseudomonas cichorii (Swingle) Stapp \\
Freesia & Bacterial scab & Pseudomonas marginata (McCull.) Stapp \\
Geranium & Leaf spot and blight & Xanthomonas campestris pv. pelargonii (Brown) Dye \\
& Wilt & Xanthomonas spp. \\
& Pseudomonas leaf spot & Pseudomonas erodii Lewis and P. cichorii \\
Gerbera & Bacterial blight & Pseudomonas cichorii \\
Gladiolus & Bacterial leaf rot & Pseudomonas marginata \\
& Leaf spot and neck rot & Xanthomonas campestris pv. gummisudans \\
& & (McCull.) Young, Dye et al. \\
Lily & Bulb rot & Clavibacter (Corynebacterium) michiganense (Smith) Jensen \\
Orchids & & \\
Dendrobium & Leaf spot and blight & Erwinia chrysanthemii \\
Poinsettia & Bacterial soft rot & Pseudomonas gladioli Severini pv. gladioli \\
& Bacterial canker & Clavibacter (Corynebacterium) spp. \\
& Bacterial leaf spot & Xanthomonas campestris (Pammel) Dawson \\
Rose & Soft rot and stem rot & Erwinia spp. \\
& Bacterial leaf spot & Pseudomonas syringae van Hall \\
& Crown gall & Agrobacterium tumefaciens \\
\hline
\end{tabular}

gen recognition/signal transduction or biosynthesis of inducible defense products, such as phytoalexins, pathogenesis-related proteins, and structural proteins (Lamb et al., 1992). Several examples exist for applying this strategy against fungal pathogens, including Rhizoctonia solani Kühn (damping-off) (Broglie et al., 1991).

Less progress has been made in combating bacterial diseases; a few examples exist for non-florist crops with host-pathogen systems that show gene $\times$ gene interaction (Flor, 1971). In tomato, restriction fragment length polymorphisms (RFLPs), genetic linkage maps, and $\mathrm{F}_{2}$ segregating progeny from crosses of near-isogenic lines were used together to identify a tomato chromosome region and a subsequent cDNA clone (CD127) encoding a Pto gene for resistance to those races of Pseudomonas syringae pv. tomato Okabe with the corresponding avirulence gene avrPto (Martin et al., 1993). Similar map-based cloning is in progress for isolating the Arabidopsis gene RPM1 for resistance to $P$. syringae $\mathrm{pv}$. maculicola $\mathrm{McCulloch}$ carrying avrPmaA 1 (T. Debener, H. Liedgens, M. Gerwin, and J. Dangl, unpublished data).

Despite the success of this approach, immediate application of map-based cloning to flower crops appears remote. Genetic linkage and RFLP maps are not yet developed for the major temperate and subtropical ornamentals, and many ornamentals may be unsuitable due to genome size and organization, inbreeding depression, and long generation times. However, a disease resistance gene identified by map-based cloning in one crop could possibly be used to identify a structurally and functionally conserved gene in a target florist crop. For example, the tomato Pto gene family clone CD127 shared homology with DNA regions of at least 11 other crop species (Martin et al., 1993).

A second strategy, gene tagging, is being applied with rapid progress in several crops, including Arabidopsis thaliana L., a model plant with a small genome. In this approach, genes of interest are identified through use of transposable elements (Altmann et al., 1992) or T-DNA insertion (Feldmann and Marks, 1987). Direct application of this approach may be less valuable for polyploid ornamentals, such as roses, chrysanthemums, and orchids, or species with large genomes (genome sizes of the vast majority of ornamental breeding species and hybrids are currently unknown). However, gene sequences identified in Arabidopsis could be used to screen genomes of ornamentals in the event that some resistance genes are conserved across genera (Dangl et al., 1992). Alternative strategies that do not rely on RFLP or genetic maps are emerging and are being used to elucidate and manipulate the host-pathogen gene recognition response (Keen et al., 1993).

\section{Novel approaches: Studies using nonplant antibacterial genes}

Recent advances have led to the identification, and subsequent gene cloning, of several peptides with antibacterial properties in arthropods and some mammalian species. These peptides work independently or in concert to kill a range of important Gram-positive and -negative bacteria. Their activities vary, but several appear suitable against plant pathogens (Destéfano-Beltrán et al., 1990; Nordeen et al., 1992; Sinden et al., 1993). We limit our discussion to three broad categories of antimicrobial proteins: insect immune proteins, animal defense proteins, and lysozymes, followed with examples of natural or synthetic antibacterial genes that have been cloned, modified, and introduced for expression in plants.

Insect immune proteins. H. Boman's group in Sweden, using the giant silkmoth Hyalophora cecropia L., initially isolated and characterized insect antibacterial peptides (Table 2) in some detail during the late 1970s and the 1980s (Boman et al., 1991; Dunn, 1991). These

Table 2. Some antibacterial peptides isolated from arthropods (adapted, in part, from Dunn, 1991).

\begin{tabular}{|c|c|c|c|}
\hline Species & $\begin{array}{l}\text { Life stage/ } \\
\text { tissue }^{z}\end{array}$ & $\begin{array}{l}\text { Defensive } \\
\text { protein }\end{array}$ & $\begin{array}{c}\text { Molecular } \\
\text { wt } \\
(\mathrm{kDa})\end{array}$ \\
\hline \multirow{5}{*}{$\begin{array}{l}\text { Hyalophora cecropia } \\
\text { (giant silkmoth) }\end{array}$} & & & \\
\hline & $\mathrm{P}$ & Lysozyme & 15 \\
\hline & $\mathrm{P}$ & Cecropins & 4 \\
\hline & $\mathrm{P}$ & Attacins & 22 \\
\hline & $\mathrm{P}$ & P4 & 48 \\
\hline \multirow{3}{*}{$\begin{array}{l}\text { Sarcophaga peregrina Meigen } \\
\text { (fleshfly) }\end{array}$} & & & \\
\hline & $\mathrm{L}$ & Sarcotoxins I-III & $7-26$ \\
\hline & CL & Sapecin & 4 \\
\hline \multicolumn{4}{|l|}{ Phormia terraenovae Robineau } \\
\hline \multirow[t]{3}{*}{ Desvoidy (blowfly) } & $\mathrm{L}$ & Diptericins & 9 \\
\hline & $\mathrm{L}$ & Defensins & 4 \\
\hline & $\mathrm{L}$ & Cecropin-like & 4 \\
\hline \multirow{5}{*}{$\begin{array}{l}\text { Manduca sexta } \mathrm{L} . \\
\text { (tobacco hornworm) }\end{array}$} & & & \\
\hline & $\mathrm{L}$ & Lysozyme & 14 \\
\hline & $\mathrm{L}$ & Cecropin-like & 4 \\
\hline & $\mathrm{L}$ & Attacin-like & 22 \\
\hline & $\mathrm{L}$ & P4-like & 48 \\
\hline \multicolumn{4}{|l|}{ Drosophila melanogaster } \\
\hline \multirow[t]{3}{*}{ Meigen L. (fruitfly) } & A & Cecropins & 4 \\
\hline & GT & Andropin & 6 \\
\hline & A & Diptericin & 9 \\
\hline \multirow{2}{*}{$\begin{array}{l}\text { Apis mellifera } \mathrm{L} \text {. } \\
\text { (honeybees) }\end{array}$} & & & \\
\hline & $\begin{array}{l}\text { A } \\
\text { A }\end{array}$ & $\begin{array}{l}\text { Apidaecins } \\
\text { Abaecins }\end{array}$ & $\begin{array}{l}2 \\
4\end{array}$ \\
\hline \multirow{3}{*}{$\begin{array}{l}\text { Zophobas atratus Blanchard } \\
\text { (tenebrionid beetle) } \\
\text { Tachypleus tridentatus Leach } \\
\text { (horsehoe crab) }\end{array}$} & $\mathrm{L}$ & Coleoptericin & 8 \\
\hline & & & \\
\hline & $\mathrm{H}$ & Tachyplesins & 2 \\
\hline
\end{tabular}


peptides are the products of humoral (cell-free) immunity in insects after induction by bacteria. Immune proteins have now been isolated from various insects and other arthropods. This continues to be an active area of research.

Three classes of bactericidal proteins have been identified in the giant silkmoth: lysozymes, attacins, and cecropins (see review by Boman et al., 1991). The cecropia lysozyme is very similar to chicken egg white lysozyme in enzyme activity. Lysozymes are lytic muramidases that cleave the glycosidic bond between the C-1 of $N$ acetylmuramic acid and the C-4 of $\mathrm{N}$-acetylglucosamine in the bacterial peptidoglycan (Jolls and Jolls, 1984). Six forms of attacins, with an approximate molecular weight of $20 \mathrm{kDa}$, are the largest antibacterial peptides found in the hemolymph of immunized cecropia pupae. Attacin appears to inhibit the synthesis of outer membrane proteins in E. coli by interfering with transcription (Carlsson et al., 1991). There are three major forms of cecropins. These cecropins are basic and small, $\approx 4 \mathrm{kDa}$. They are the most potent group of the cecropia antibacterial factors, with a broad spectrum of activity against Gramnegative and Gram-positive bacteria (Jaynes et al., 1987). Insect, and mammalian, cecropins are considered lytic peptides, with the primary targets being the inner and outer bacterial membrane (Boman, 1991).

Noninsect animal defense proteins. Other antibacterial peptides that kill a wide variety of bacteria and fungi have been isolated from diverse animal tissues (Table 3). Mammalian cells and tissues contain one group of proteins called defensins (Ganz et al., 1990), small basic molecules of 29 to 34 amino acid residues with low molecular weights, $\approx 3$ to $5 \mathrm{kDa}$. Like cecropins, defensins are lytic peptides that form pores (ion channels) in bacterial and artificial membranes (Boman, 1991; Lehrer et al., 1991). Some examples of defensins are from human, rabbit, and rat sources (Table 3). Recently, Selsted et al. (1992) reported a novel bactericidal peptide, indolicidin, with only 13 amino acid residues isolated from the bovine immune system. A Grampositive and a Gram-negative bacterium were killed in $2 \mathrm{~h}$ by the

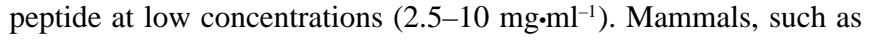
pigs, also produce cecropin-like peptides with molecular weights similar to those found in insects (Table 3 ). Other defense proteins from mammals include bactericidal/permeability-increasing factor (BPI) proteins (Table 3) (Lehrer and Ganz, 1990) and lactoferrin (Erdei et al., 1994). Additional peptides continue to be discovered.

Amphibian skin contains a high percentage of antimicrobial factors. Magainins are one group of small peptides (23 amino acid residues) isolated from the African clawed frog, Xenopus laevis Daudin (Berkowitz et al., 1990; Zasloff, 1987). Magainins and derivatives have broad-spectrum activity on Gram-negative and Grampositive bacteria, fungi, and parasites (Berkowitz et al., 1990); however, the low potency of native magainins may be inappropriate for plant protection purposes (J. Jaynes, personal communication).

Lysozymes. The most intensively studied lysozymes are those from avian egg white, although mammalian, insect, and invertebrate tissues also contain lysozymes. Differing groups of lysozymes differ in

Table 3. Some antibacterial peptides isolated from mammals and amphibians

\begin{tabular}{|c|c|c|}
\hline Species & $\begin{array}{l}\text { Defensive } \\
\text { protein }\end{array}$ & $\begin{array}{c}\text { Molecular } \\
\text { wt } \\
(\mathrm{kDa})\end{array}$ \\
\hline \multirow[t]{2}{*}{ Human } & Defensin & 5 \\
\hline & $\begin{array}{l}\text { Bactericidal/ } \\
\text { permeability increasing (BPI) }\end{array}$ & $55-60$ \\
\hline \multirow[t]{2}{*}{ Rabbit } & Defensins & 4 \\
\hline & Neutrophil peptides & 4 \\
\hline \multirow[t]{4}{*}{ Pig } & Cecropin P1 & 3.3 \\
\hline & Tracheal antimicrobial peptide & $3.4-4.0$ \\
\hline & BPI & 25 \\
\hline & Indolicidin & 1.4 \\
\hline Rat & Defensins & $3.2-3.8$ \\
\hline Mouse & Cryptdins & 4 \\
\hline Guinea pig & Neutrophil cationic peptides & 2.6 \\
\hline \multicolumn{3}{|l|}{ Xenopus laevis } \\
\hline \multirow[t]{2}{*}{ (African clawed frog) } & Magainins & $2-3$ \\
\hline & PGQ & $1.4-2.0$ \\
\hline $\begin{array}{l}\text { Bombina variegata } \mathrm{L} \text {. } \\
\quad \text { (frog) }\end{array}$ & Bombinin-like & 3 \\
\hline
\end{tabular}

substrate specificity (Jollès and Jollès, 1984), with molecular weights ranging from 14 to $\approx 25 \mathrm{kDa}$. Many bacteriophage lysozyme genes and their protein products have been isolated, cloned, and sequenced. Usually two or three lytic proteins are involved in the lytic cycle of bacteriophage. These proteins lyse the bacterial host, which results in the release of new phage particles (Young, 1992). Several genes for phage lysis proteins have been cloned into plant gene expression vectors.

Studies toward genetic engineering for bacterial resistance. Following the suggestions of Jaynes et al. (1987) that genes encoding lytic and other antimicrobial peptides can be engineered to increase bacterial disease resistance in plants, several natural (attacin, chicken lysozyme, T4 phage lysozyme, P22 phage genes 13 and 19, lactoferrin, and cecropin B) or synthetic (SB37, Shiva series) antibacterial genes were used to develop plant-expressible gene constructs (DestéfanoBeltrán et al., 1990; Hippe et al., 1989; Trudel et al., 1992) and then engineered into tobacco and potato. Tobacco transgenic for the modified cecropin Shiva-1 showed resistance to Pseudomonas solanacearum Smith in the form of delayed symptoms and decreased plant mortality relative to controls (Jaynes et al., 1993). Potato transgenic for the bacteriophage T4 lysozyme gene with an alpha-amylase export signal sequence showed increased resistance to Erwinia carotovora pv. atroseptica van Hall with lower tuber maceration and higher sprouting capability compared to controls (Düring et al., 1993). Homogenates of transgenic tobacco tissues expressing a hen egg white lysozyme were active against Micrococcus spp. in lysoplate assays (Trudel et al., 1992). Potato tubers expressing a gene for the cecropin derivative SB37 ligated to an alpha-amylase secretory sequence indicated significant, but moderate, differences in soft rot among the tubers from control potato plants and transformants challenged with Erwinia carotovora spp. (Hassan et al., 1993). Leaf extract of potato transgenic for SB37 showed activity against $P$. solanacearum race 3 (Montanelli and Nascari, 1991). Tobacco transgenic for human lactoferrin appears resistant to Pseudomonas spp. (Z. Zhang, D.P. Coyne, and A. Mitra, unpublished data).

From these reports, it appears that expression of antibacterial genes in plants may confer potentially effective bacterial disease resistance. Current studies are expanding the targets for insect immune genes and their derivatives to include several horticultural crops (Jaynes, 1993). This strategy could be similarly applied to florist crops when successful gene transfer and tissue culture methods are developed.

\section{Genetic engineering of floricultural crops}

Gene transfer, such as is possible through genetic engineering, is particularly attractive for ornamentals with a lengthy juvenile phase, such as roses, orchids, bulb crops, and tropical exotics. Goals of ornamental genetic engineering appear thus far to have focused on altering phenotype, such as flower color, rather than on decreasing production costs, such as by incorporating disease resistance. Methods for engineering all the major florist crops exist (Table 4), although regeneration difficulties and cultivar differences still limit routine application of these methods (Hutchinson et al., 1992). Development of genotype-independent tissue culture and gene-transfer protocols are a focus of several research programs.

\section{Control of bacterial blight in Anthurium : Current research}

Anthurium andraeanum Linden ex André and its hybrids, A. andraeanum Hort., are economically important ornamental monocots for subtropical and tropical regions. Anthurium is used as a cut flower, flowering potted plant, and more recently as a landscape plant. Hawaii currently supplies about one-fifth of the global production. Anthurium is also widely cultivated in temperate climates in glasshouses, ranking 13th among cut flowers sold in the Dutch auctions.

New cultivars of this outbreeding, clonally propagated crop are developed through sexual hybridization, progeny evaluation, and selection. There are good opportunities for interspecific hybridization within the genus (Anthurium consists of $\approx 1000$ species). The Univ. of Hawaii has an active breeding program, with more than two dozen cultivars released in the past 30 years (Kamemoto and Kuehnle, 1995). 
Table 4. Genetic engineering feasibility for some florist crops.

\begin{tabular}{lll}
\hline Crop & \multicolumn{1}{c}{ Method } & \multicolumn{1}{c}{ Selected references } \\
\hline Anthurium & Agrobacterium & Kuehnle and Sugii, 1991a \\
Carnation & Agrobacterium & Lu et al., 1991 \\
Chrysanthemum & Agrobacterium & Courtney-Gutterson et al., 1993 \\
Gerbera & Agrobacterium & Elomaa et al., 1993 \\
Gladiolus & Agrobacterium & Graves and Goldman, 1987 \\
Lily & Agrobacterium & Cohen and Meredith, 1992 \\
& Particle gun & Peñafiel and Kamo, 1994 \\
Orchid & Particle gun & Kuehnle and Sugii, 1992 \\
Rose & Agrobacterium & Firoozabady et al., 1994 \\
Tulip & Particle gun/Agro & Wilmink et al., 1992 \\
\hline
\end{tabular}

Genetic engineering of anthurium recently became feasible after it was shown that some cultivars can be infected by Agrobacterium tumefaciens Smith \& Townsend (Kuehnle and Sugii, 1991a), a wellestablished vector for plant genetic transformation. Tissue culture protocols were also available for some Hawaiian cultivars (Kuehnle and Sugii, 1991b). However, as a perennial crop with a long juvenile stage ( 2 to 3 years) and slow seed maturation (6 months), the impact of classical breeding efforts and transgenic germplasm takes many years to be realized.

Bacterial blight and its current control. Due to the outbreak of a bacterial blight in Hawaii in the early 1980s (Nishijima and Fujiyama, 1985), Hawaii's anthurium production steadily declined between 1986 and 1993 from a farmgate value of $\$ 10$ million to about \$6 million. Blight of anthurium is caused by the bacterium Xanthomonas campestris pv. dieffenbachiae McCull. \& Pirone (Xcd). Most commercial cultivars are susceptible to Xcd; the bacterium infects at least 11 other ornamental aroids in addition to anthurium and can cause foliar and systemic symptoms in anthurium. Foliar symptoms include water-soaked and necrotic spots, usually starting at the leaf margin due to entry at the hydathodes. Systemic infections lead to a general yellowing of entire leaf blades. Plants with systemic infection in the stem, petioles, and spathes have high internal bacterial populations and usually die (Nishijima and Fujiyama, 1985). The disease can be spread by various means, such as splashing rain or irrigation, or the use of contaminated cutting tools during cultural operations, such as pruning and handling. Most Hawaiian anthurium production is in shadehouses, which are exposed to rain and overhead irrigation.

Current control measures include strict sanitation (Nishijima, 1988). Although the antibiotic combination of streptomycin and oxytetracycline has been used in some cases, the bacteria developed streptomycin resistance in a short time. Therefore, antibiotics are not recommended for routine control (Alvarez et al., 1989; Nishijima, 1988). Studies using several chemicals, such as Physan (Maril Products, Tustin, California) and Aliette 80 WP (Rhone-Poulenc Agrochimie, Lyon, France), have led to some abatement of bacterial infection (Alvarez et al., 1990, 1991). A clean stocks program is currently being developed with Hawaii state resources. Despite implementation of controls by many growers, annual anthurium production has not increased.

Conventional breeding. Using classical hybridization and selection in our breeding program, we have attempted to transfer the apparent systemic resistance from Anthurium antioquiense Engler to the cultivated $A$. andraeanum Hort. $\mathrm{F}_{1}$ hybrids had a high degree of resistance to the bacteria. However, due to the small flower of $A$. antioquiense, the $\mathrm{F}_{1}$ hybrids have to be backcrossed to the cultivated varieties to obtain resistant plants with horticulturally desirable characteristics (Kamemoto et al., 1990). This objective could take a decade, or longer, to achieve. More importantly, the genetics of the available resistance are not understood, and the quality of the final resistance may not be as high as desirable. Using other tolerant germplasm, we recently released two cultivars with improved resistance, 'Kalapana' and 'Tropic Ice' (Kamemoto and Kuehnle, 1995). After several years, both cultivars eventually succumbed to blight (anthuriums remain in production from 5 to 9 years). The mode of inheritance of the available resistance in the breeding germplasm remains to be determined.

Genetic engineering. The overall goal of our research is to introduce various antibacterial genes and synthetic derivatives from
Hyalophora cecropia and bacteriophages, in suitable vectors, into anthurium cultivars followed by plant characterization and evaluation for bacterial resistance. We used two cultivars in our study, 'Rudolph' and 'UH1060'. Several lines of putatively transformed plants were obtained for the antibacterial genes Att, P13, and T4 from constructs $\mathrm{Ca} 2 \mathrm{Att}, \mathrm{Ca} 2 \mathrm{P} 13$, and $\mathrm{Ca} 2 \mathrm{~T} 4$, respectively, as shown by polymerase chain reaction and Western analysis (Chen, 1993).

Resistance of regenerated anthurium was tested by challengeinoculation with the highly virulent Xcd strain D150. Kanamycinresistant plantlets with $\mathrm{Ca} 2 \mathrm{Att}, \mathrm{Ca} 2 \mathrm{P} 13$, and $\mathrm{Ca} 2 \mathrm{~T} 4$ showed a noticeable delay in disease symptom development compared with nontransformed controls (Chen, 1993). Counts from bacterial reisolation of inoculated $\mathrm{Ca} 2 \mathrm{Att}$ plantlets correlated well with the degree of disease symptoms. Greenhouse spray inoculation and natural infection studies of mature $\mathrm{Ca} 2 \mathrm{Att}$ and $\mathrm{Ca} 2 \mathrm{~T} 4$ plants indicated some tolerance among individuals to Xcd strain D150. However, due to symptomless infections of nontransformed controls, proper statistical analysis of our data becomes essential. Our results with these genes are supported by other studies with delayed symptom expression or resistance in apple transgenic for attacin (Norelli et al., 1993) and potato transgenic for T4 (Düring et al., 1993). Thus, the use of cecropia and bacteriophage genes may confer some bacterial disease tolerance into anthurium. However, tests for effectiveness need to include more samples and more field tests to identify lines with suitable levels of resistance.

\section{Prospects}

Results from the limited body of work using lytic peptides against bacterial pathogens remains encouraging. Other developing strategies should also be considered. For example, stimulation in the plant of systemic acquired resistance (SAR) (Ryals et al., 1994) is one area that deserves attention by researchers for potential use in florist crop protection. Apparently, this type of resistance is effective against bacterial pathogens in the field for several weeks (Ku'c, 1982) and can be induced by a variety of biotic and abiotic agents. By itself, this geneinduction strategy could be particularly useful for fast-cycling crops such as chrysanthemum (10- to 12 -week production time). For genetic improvement purposes, it may be possible to select and hybridize plants with strong SAR. Akin to this is high phytoalexin production in Fusarium-resistant, but not susceptible, carnation (Baayen et al., 1991). A second strategy is extension of the parasite-derived resistance concept (Sanford and Johnston, 1985) to those bacterial diseases whose symptoms in ornamentals may be associated with production of a bacterial toxin (Walton and Panaccione, 1993). The value of this approach is evident in examples of reduced toxin sensitivity, or none, in transgenic tobacco expressing bacteria-derived genes (Anzai et al., 1989; de la Fuente-Martinez et al., 1992). Finally, since protoplast and tissue culture manipulations have improved greatly for ornamentals in recent years, selection of resistance among somaclones (van den Bulk, 1991) or introgression of resistance genes from wild relatives merit further attention by breeders.

\section{Literature Cited}

Altmann, T., R. Schmidt, and L. Willmitzer. 1992. Establishment of a gene tagging system in Arabidopsis thaliana based on the maize transposable element Ac. Theor. Appl. Genet. 84:371-383.

Alvarez, A., R. Lipp, and B. Bushe. 1989. Resistance of bacteria to antibiotics used for control of anthurium blight, p. 11-13. In: J.A. Fernandez and W.T. Nishijima (eds.). Proc. 2nd Anthurium Blight Conf. Hawaii Inst. Trop. Agr. Human Resources 03.10.89, Univ. of Hawaii.

Alvarez, A., R. Lipp, D. Norman, and L. Gladstone. 1990. Epidemiology and control of anthurium blight, p. 27-30. In: A. Alvarez (ed.). Proc. 3rd Anthurium Blight Conf. Hawaii Inst. Trop. Agr. Human Resources 05.07.90, Univ. of Hawaii.

Alvarez, A., D. Norman, and R. Lipp. 1991. Epidemiology and control of anthurium blight, p. 15-18. In: A. Alvarez, D.C. Deardorff, and K.B. Wadsworth (eds.). Proc. 4th Hawaii Anthurium Industry Conf. Hawaii Inst. Trop. Agr. Human Resources 04.06.91., Univ. of Hawaii.

Anzai, H., K. Yoneyama, and I. Yamaguchi. 1989. Transgenic tobacco resistant to a bacterial disease by the detoxification of a pathogenic toxin. Mol. Gen. Genet. 219:492-494.

Aragaki, M., H. Kamemoto, and K.M. Maeda. 1968. Anthracnose resistance in 
anthurium. Hawaii Agr. Expt. Sta. Prog. Rpt. 169.

Baayen, R.P., L.D. Sparnaaij, J. Jansen, and G.J. Niemann. 1991. Inheritance of resistance components in carnation against fusarium wilt. Neth. J. Plant Pathol. 97:73-86.

Baker, K.F. 1957. The U.C. system for producing healthy container-grown plants. Univ. of California Agr. Ext. Serv. Manual 23.

Berkowitz, B.A., C.L. Bevins, and M.A. Zasloff. 1990. Magainins: A new family of membrane-active host defense peptides. Biochem. Pharmacol. 39:625-629.

Boman, H.G. 1991. Antibacterial peptides: Key components needed in immunity. Cell 65:205-207.

Boman, H.G., I. Faye, G.H. Gudmundsson, J.-Y. Lee, and D.-A. Lidholm. 1991. Cell-free immunity in cecropia. A model system for antibacterial proteins. Eur. J. Biochem. 201:23-31.

Broglie, K., I. Chet, M. Holliday, R. Cressman, P. Biddle, C. Knowlton, C.J. Mauvais, and R. Broglie. 1991. Transgenic plants with enhanced resistance to the fungal pathogen Rhizoctonia solani. Science 254:1194-1197.

Carlsson, A., P. Engstrom, E.T. Tapio, and H. Bennich. 1991. Attacin, an antibacterial protein from Hyalophora cecropia, inhibits synthesis of outer membrane proteins in Escherichia coli by interfering with omp gene transcription. Infection Immunity 59:3040-3045.

Chen, F.C. 1993. Genetic engineering of anthurium for bacterial disease resistance. PhD Diss., Univ. of Hawaii, Honolulu.

Cohen, A. and C.P. Meredith. 1992. Agrobacterium-mediated transformation of Lilium. Acta Hort. 325(2):611-618.

Cooksey, D.A. 1990. Genetics of bactericide resistance in plant pathogenic bacteria. Annu. Rev. Phytopathol. 28:210-219.

Courtney-Gutterson, N., E. Firoozabady, C. Lemieux, J. Nicholas, A. Morgan, K. Robinson, A. Otten, and M. Akerboom. 1993. Production of genetically engineered color-modified chrysanthemum plant carrying a homologous chalcone synthase gene and their field performance. Acta Hort. 336:57-62.

Dangl, J.L., C. Ritter, M.J. Gibbon, L.A.J. Mur, J.R. Wood, S. Goss, J. Mansfield, J.D. Taylor, and A. Vivian. 1992. Functional homologs of the Arabidopsis RPM1 disease resistance gene in bean and pea. Plant Cell 4:1359-1369.

de la Fuente-Martinez, J.M., G. Mosqueda-Cano, A. Alvarez-Morales, and L. Herrera-Estrella. 1992. Expression of a bacterial phaseolotoxin-resistant ornithyl transcarbamylase in transgenic tobacco confers resistance to Pseudomonas syringae pv. phaseolicola. Bio/Technology 10:905-909.

Destéfano-Beltrán, L., P.G. Nagpala, S. Cetiner, J.H. Dodds, and J.M. Jaynes. 1990. Enhancing bacterial and fungal disease resistance in plants: Application to potato, p. 205-221. In: M.E. Vayda and W.D. Park (eds.). The molecular and cellular biology of the potato. CAB International, Wallingford, U.K

Dons, J.J.M., C. Mollema, W.J. Stiekema, and B. Visser. 1991. Routes to the development of disease resistant ornamentals, p. 387-417. In: J. Harding, F. Singh, and J.N.M. Mol (eds.). Genetics and breeding of ornamental species. Kluwer Academic, Dordrecht.

Dunn, P.E. 1991. Insect antibacterial proteins, p. 19-44. In: G.W. Warr and N Cohen (eds.). Phylogenesis of immune functions. CRC, Boca Raton, Fla.

Düring, K., P. Porsch, M. Fladung, and H. Lörz. 1993. Transgenic potato plants resistant to the phytopathogenic bacterium Erwinia carotovora. Plant J. 3:587-598.

Elomaa, P., J. Honkanen, R. Puska, P. Sappanen, Y. Helariutta, M. Mehto, M. Kotilainen, L. Nevalainen, and T.H. Teeri. 1993. Agrobacterium-mediated transfer of antisense chalcone synthase cDNA to Gerbera hybrida inhibits flower pigmentation. Bio/Technology 11:508-511.

Erdei, J., A. Forsgren, and A.S. Naidu. 1994. Lactoferrin binds to porins OmpF and OmpC in Escherichia coli. Infection Immunity 62:1236-1240.

Feldmann, K.A. and M.D. Marks. 1987. Agrobacterium-mediated transformation of germinating seeds of Arabidopsis thaliana: A non-tissue culture approach. Mol. Gen. Genet. 208:1-9.

Firoozabady, E., Y. Moy, N. Courtney-Gutterson, and K. Robinson. 1994. Regeneration of transgenic rose (Rosa hybrida) plants from embryogenic tissue. Bio/Technology 12:609-613.

Flor, H.H. 1971. Current status of the gene-for-gene concept. Annu. Rev. Phytopathol. 9:275-296.

Ganz, T., M.E. Selsted, and R.I. Lehrer. 1990. Defensins. Eur. J. Haematol. $44: 1-8$.

Graves, A.C. and S.L. Goldman. 1987. Agrobacterium tumefaciens-mediated transformation of the monocot genus Gladiolus: Detection of the expression of T-DNA-encoded genes. J. Bacteriol. 169:1745-1746.

Hassan, M., S.L. Sinden, R.S. Kobayashi, R.O. Nordeen, and L.D. Owens. 1993. Transformation of potato (Solanum tuberosum) with a gene for an anti-bacterial protein, cecropin. Acta Hort. 336:127-130.

Hippe, S., K. Düring, and F. Kreuzaler. 1989. In situ localization of a foreign protein in transgenic plants by immunoelectron microscopy following high pressure freezing. Freeze substitution and low temperature embedding. Eur. J. Cell Biol. 50:230-234.
Hutchinson, J.F., V. Kaul, G. Maheswaran, J.R. Moran, M.W. Graham, and D. Richards. 1992. Genetic improvement of floricultural crops using biotechnology. Austral. J. Bot. 40:765-787.

Jaynes, J.M. 1993. Use of genes encoding novel lytic peptides and proteins that enhance microbial disease resistance in plants. Acta Hort. 336:33-39.

Jaynes, J.M., P. Nagpala, L. Destéfano-Beltrán, J.H. Huang, J. Kim, T. Denny, and S.M. Cetiner. 1993. Expression of a Cecropin B lytic peptide analog in transgenic tobacco confers enhanced resistance to bacterial wilt caused by Pseudomonas solanacearum. Plant Sci. 89:43-54.

Jaynes, J.M., K.G. Xanthopoulos, L. Destéfano-Beltrán, and J.H. Dodds. 1987. Increasing bacterial disease resistance in plants utilizing antibacterial genes from insects. BioEssays 6:263-270.

Jollès, P. and J. Jollès. 1984. What's new in lysozyme research? Mol. Cellular Biochem. 63:165-189.

Kamemoto, H. and A.R. Kuehnle. 1995. Breeding anthuriums in Hawaii. Univ. of Hawaii Press, Honolulu.

Kamemoto, H., A. Kuehlne, J. Kunisaki, M. Aragaki, T. Higaki, and J. Imamura. 1990. Breeding for bacterial blight resistance in anthurium, $p$. 45-48. In: A.M. Alvarez (ed.). Proc. 3rd Anthurium Blight Conf. Hawaii Inst. Trop. Agr. Human Resources 05.07.90, Univ. of Hawaii.

Keen, N.T., A. Bent, and B. Stastawicz. 1993. Plant disease resistance genes: Interactions with pathogens and their improved utilization to control plant diseases, p. 65-88. In: I. Chet (ed.). Biotechnology in plant disease control. Wiley-Liss, New York.

$\mathrm{Ku}$ 'c, J. 1982. Induced immunity to plant disease. BioScience 32:854-860.

Kuehnle, A.R. and N. Sugii. 1991a. Induction of tumors in Anthurium andraeanum by Agrobacterium tumefaciens. HortScience 26:1325-1328.

Kuehnle, A.R. and N. Sugii. 1991b. Callus induction and plantlet regeneration in tissue cultures of Hawaiian anthuriums. HortScience 26:919-921.

Kuehnle, A.R. and N. Sugii. 1992. Transformation of Dendrobium orchid using particle bombardment of protocorms. Plant Cell Rpt. 11:484-488.

Lamb, C.J., J.A. Ryals, E.R. Ward, and R.A. Dixon. 1992. Emerging strategies for enhancing crop resistance to microbial pathogens. Bio/Technology 10:1436-1445.

Lehrer, R.I. and T. Ganz. 1990. Antimicrobial polypeptides of human neutrophils. Blood 76:2169-2181.

Lehrer, R.I., T. Ganz, and M.E. Selsted. 1991. Defensins: Endogenous antibiotic peptides of animal cells. Cell 64:229-230.

Lu, C-Y., G. Nugent, T. Wardley-Richardson, S.F. Chandler, R. Young, and M.J. Dalling. 1991. Agrobacterium-mediated transformation of carnation (Dianthus caryophyllus L.). Bio/Technology 9:864-868.

Martin, G.B., S.H. Brommonschenkel, J. Chunwongse, A. Frary, M.W. Ganal, R. Spivey, T. Wu, E.D. Earle, and S.D. Tanksley. 1993. Map-based cloning of a protein kinase gene conferring disease resistance in tomato. Science 262:1432-1436.

Montanelli, C. and G. Nascari. 1991. Introduction of an antibacterial gene in potato (Solanum tuberosum L.) using a binary vector in Agrobacterium rhizogenes. J. Genet. Breeding 45:307-316.

Nishijima, W.T. 1988. Anthurium blight: An overview, p. 6-8. In: A. Alvarez (ed.). Proc. First Anthurium Blight Conf. Hawaii Inst. Trop. Agr. Human Resources 02.04.88, Univ. of Hawaii.

Nishijima, W.T. and D.K. Fujiyama. 1985. Bacterial blight of anthurium. Univ. of Hawaii Coop. Ext. Serv. Commodity Fact Sheet AN-4(A).

Nordeen, R.O., S.L. Sinden, J.M. Jaynes, and L.D. Owens. 1992. Activity of cecropin SB37 against protoplasts from several plant species and their bacterial pathogens. Plant Sci. 82:101-107.

Norelli, J., H. Aldwinckle, L. Destéfano-Beltrán, and J. Jaynes. 1993. Transgenic apple plants containing lytic proteins have increased resistance to Erwinia amylovora. 1993 Amer. Phytopathol. Soc. Annu. Mtg. (Abstr. A555)

Peñafiel, J.M. and K. Kamo. 1994. Transient GUS expression in lily bulb scales and cell suspensions transformed by particle bombardment. In Vitro 30A:67.

Powell, C.C. and R.K. Lindquist. 1992. Ball pest and disease manual. Ball Publishing, Geneva, Ill.

Robinson, K.E.P. and E. Firoozabady. 1993. Transformation of floricultural crops. Scientia Hort. 55:83-99.

Ryals, J., S. Uknes, and E. Ward. 1994. Systemic acquired resistance. Plant Physiol. 104:1109-1112.

Sanford, J.C. and S.A. Johnston. 1985. The concept of parasite-derived resistance- deriving resistance genes from the parasite's own genome. J. Theor. Biol. 113:395-405.

Selsted, M.E., M.J. Novotny, W.L. Morris, Y.-Q. Tang, W. Smith, and J.S. Cullor. 1992. Indolicidin, a novel bactericidal tridecapeptide amide from neutrophils. J. Biol. Chem. 267:4292-4295.

Sinden, S.L., R.S. Kobayashi, R.O. Nordeen, and L.D. Owens. 1993. Perspectives on controlling potato soft rot with foreign genes for antibacterial compounds. Acta Hort. 336:79-84.

Sparnaaij, L.D. 1991. Breeding for disease and insect resistance in flower crops, p. 179-211. In: J. Harding, F. Singh, and J.N.M. Mol (eds.). Genetics 
and breeding of ornamental species. Kluwer Academic, Dordrecht.

Trudel, J., C. Potvin, and A. Asselin. 1992. Expression of active hen egg white lysozyme in transgenic tobacco. Plant Sci. 87:55-67.

van den Bulk, R.W. 1991. Application of cell and tissue culture and in vitro selection for disease resistance breeding-A review. Euphytica 56:269285.

Walton, J.D. and D.G. Panaccione. 1993. Host-selective toxins and disease specificity: Perspectives and progress. Annu. Rev. Phytopathol. 31:275303.

Whealey, C.A. 1994. Vegetative geranium production: Cutting to the chase. GrowerTalks 58:34-43.
Wienand, U. and H. Saedler. 1987. Plant transposable elements: Unique structures for gene tagging, p. 205-227. In: T.H. Hohn and J. Schell (eds.). Plant DNA infectious agents. Springer Verlag, New York.

Wilmink, A., B.C.E. van den Ven, and J.J.M. Dons. 1992. Expression of the GUS-gene in the monocot tulip after introduction by particle bombardment and Agrobacterium. Plant Cell Rpt. 11:76-80.

Young, R. 1992. Bacteriophage lysis: Mechanism and regulation. Microbiol. Rev. 56:430-481.

Zasloff, M. 1987. Magainins, a class of antimicrobial peptides from Xenopus skin: Isolation, characterization of two active forms, and partial cDNA sequence of a precursor. Proc. Natl. Acad. Sci. USA 84:5449-5453.

\title{
Use of Random Amplified Polymorphic DNA Markers in Breeding for Major Gene Resistance to Plant Pathogens
}

\author{
James D. Kelly ${ }^{1}$ \\ Department of Crop and Soils Sciences, Michigan State University, East Lansing, MI 48824
}

\begin{abstract}
Markers are of interest to plant breeders as a source of genetic information on crops and for use in indirect selection of traits linked with the markers. Selection based on the marker would be more efficient provided there was tight linkage between the marker and the trait of interest $[<5$ centimorgans $(\mathrm{cM})]$ and assuming selection for the marker was more convenient (faster, cheaper, reproducible, expressed earlier). Markers for disease resistance offer the additional advantage of permitting selection for resistance in the absence of the pathogen or a variant of the pathogen. This feature is of particular interest to a plant breeder who may be reluctant either to work directly with or to introduce a pathogen where quarantine restrictions prevent its introduction. Markers linked to various resistance genes would greatly facilitate breeding for multiple disease resistance, since selection based on markers could be readily incorporated into a breeding program. This approach would be of particular interest with pathogens that exhibit inconsistent expression due to environmental or other factors. A single technology that would indirectly permit selection for diverse disease resistance genes would be highly desirable and extremely useful in breeding for disease resistance. Indirect selection as an efficient and practical means of developing disease-resistant cultivars will depend on the identification of markers that are easy to score and tightly linked to different resistance genes.
\end{abstract}

\section{TYPE OF MARKER}

Until recently, indirect selection has not been practical due to the lack of suitable markers, or the undesirable pleiotropic effects of many morphological markers. In recent years, marker-assisted selection (MAS) has received attention as a useful method for improving major gene disease resistance in horticultural crops. The concept of MAS, when applied to monogenic disease resistance, dictates that selection for one or more resistance genes is conducted by selecting a marker (or two flanking markers) tightly linked to the gene of interest (Melchinger, 1990). The use of this approach with morphological markers has been limited primarily due to the few such markers available in most crop

Received for publication 20 Oct. 1994. Accepted for publication 16 Nov. 1994. Research supported in part by grant DAN 1310-G-SS-6008-00 from the USAID Bean/Cowpea Collaborative Research Support Program, the Michigan Agricultural Experiment Station, and the U.S. Dept. of Agriculture (USDA)Agricultural Research Service. Mention of a trademark or a proprietary product does not constitute a guarantee or warranty of the product by the USDA and does not imply its approval to the exclusion of other products that may also be suitable. I acknowledge the assistance of L. Afanador, S.D. Haley, P.N. Miklas, J.R. Stavely, and R.A. Young in the development of RAPD markers in common bean and for their critical review of this manuscript. The cost of publishing this paper was defrayed in part by the payment of page charges. Under postal regulations, this paper therefore must be hereby marked advertisement solely to indicate this fact.

${ }^{1}$ Professor. species, their major effects on plant phenotype (often deleterious mutants), and the inability to score multiple morphological mutant traits in a single segregating population (Paterson et al., 1991). The development of markers based on allelic variants of specific enzymes (isozymes; Tanksley and Orton, 1983) and, most notably, of those based on variation in the length of DNA fragments obtained by digestion with restriction endonucleases (RFLPs; Botstein et al., 1980) has overcome these limitations.

RFLP markers offer significant advantages over isozymes. They demonstrate more detectable loci and alleles, are phenotypically neutral, and can be scored at any stage of plant development. RFLP markers have been used extensively to "tag" useful genes in common bean (Phaseolus vulgaris L., Degremont and Vallejos, 1994; Nodari et al., 1993), lettuce (Lactuca sativa L., Landry et al., 1987; Paran et al., 1991), pepper (Capsicum annuum L., Tanksley et al., 1988), potato (Solanum tuberosum L., Barone et al., 1990; Ritter et al., 1991), and tomato (Lycopersicon esculentum Mill., Klein-Lankhorts et al., 1991a; Nienhuis et al., 1987; Osborn et al., 1987; Sarfatti et al., 1991; Young et al., 1988). However, development of RFLP markers involves a tedious, expensive, multistep process that requires considerable investment in personnel, equipment, chemicals, and safety concerns if radioactive probes are used. The technology is not compatible with the needs of those breeders involved in resistance breeding and working with large populations and limited budgets.

Recently, a molecular marker based on the polymerase chain reaction (PCR) has been developed that alleviates these potential limitations. PCR was modified to develop a new form of molecular marker: the random amplified polymorphic DNA (RAPD) marker (Welsh and McClelland, 1990; Williams et al., 1990). Genetic mapping and gene tagging using RAPD markers has several advantages over other methods (Kesseli et al., 1992; Williams et al., 1990): 1) a universal set of primers can be used and screened in a short period, 2) no isolation of cloned DNA probes or preparation of hybridization filters is required, and 3) only small quantities of DNA are needed, allowing the use of simple and rapid methods for genomic isolation (Afanador et al., 1993; Edwards et al., 1991; Wang et al., 1993).

Since their inception, RAPDs have been used to tag major resistance genes in barley (Hordeum vulgare L., Barua et al., 1993), common bean (Haley et al., 1993, 1994a, 1994b, 1994c; Johnson and Gepts, 1994; Johnson et al., 1994; Jung et al., 1994; Miklas et al., 1993), lettuce (Kessili et al., 1992; Michelmore et al., 1991; Paran et al., 1991), oat (Avena sativa, L., Penner et al., 1993), rice (Oryza sativa L., Mohan et al., 1994), tomato (Klein-Lankhorts et al., 1991b; Martin et al., 1991; Williamson et al., 1994), and wheat (Triticum aestivum L., Schachermayr et al., 1994), and to assist in developing comprehensive genetic maps and within-species relationships in several plant species (alfalfa, Medicago sativa L., Echt et al., 1992; apple, Malus $\times$ domestica Borkh., Koller et al., 1993; blueberry, Vaccinium darrowi, Rowland and Levi, 1994; broccoli and cauliflower, Brassica oleracea L., Hu 
and Quiros, 1991; celery, Apium graveolens, Yang and Quiros, 1993; common bean, Jung et al., 1994, McClean et al., 1994, Nodari et al., 1993, Skroch et al., 1992; papaya, Carica papaya L., Stiles et al., 1993; peach, Prunus persica L. Batsch., Chaparro et al., 1994; soybean, Glycine $\max$ L. Merr., Williams et al., 1990; strawberry, Fragaria xananassa, Hancock et al., 1994; tomato, Foolad et al., 1993). Finally, Ragot and Hoisington (1993) have shown that cost per data point for RFLPs is less for large populations, while RAPDs are favored in smaller populations. This difference is probably immaterial in many self-pollinated crops where RFLPs lack a sufficient level of polymorphism within the species or between related breeding material (Nodari et al., 1992). RAPDs appear to detect higher levels of polymorphism and are more valuable in the construction of intraspecific genetic maps and in gene tagging research-an area where breeders are focusing currently (Haley et al., 1994d).

\section{STRUCTURE OF GENETIC POPULATIONS}

In most instances, identifying RFLPs or RAPDs linked to important resistant genes depends on the availability of pairs of backcrossderived, near-isogenic lines (NILs; Young et al., 1988). The development of NILs through backcrossing for economically important genes is costly and time consuming, but breeders have at their disposal lategeneration heterogeneous individuals within genetic populations from which NILs for a specific disease resistance trait can be isolated (Haley et al., 1994c). The use of such NILs has permitted the successful tagging of three disease resistance genes in common bean (Haley et al., 1994a, 1994b, 1994c).

An alternative strategy, bulked segregant analysis (Michelmore et al., 1991), was proposed recently to allow the rapid development of genetic populations useful for identifying RFLP or RAPD markers linked to disease resistance genes. With this method, Michelmore et al. (1991) identified three RAPD markers linked to major disease resistance genes using contrasting DNA bulks composed of $\mathrm{F}_{2}$ individuals of known genotype. Using backcross-derived populations segregating for two major rust resistance genes in common bean, Miklas et al. (1993) and Haley et al. (1993) have provided additional support for the utility of the bulked segregant method. Combining backcross introgression, characteristic of traditional NIL development, with bulked segregant analysis enhances the identification of markers that are tightly linked to the gene of interest (Haley et al., 1993; Michelmore et al., 1991; Miklas et al., 1993).

Another strategy used to facilitate gene tagging in common bean includes the creation of segregating populations where the resistance gene, originating from one gene pool, was introgressed directly or backcrossed into the other gene pool. Common bean is characterized by an extensive range of genetic variation. Biochemical, physiological, and morphological evidence strongly suggests that this variation is not distributed at random but is associated with two distinct centers of diversity commonly known as the Andean and Middle American gene pools (Gepts and Bliss, 1985; Gepts et al., 1986). This intergene-pool crossing technique was used successfully to tag two rust resistance genes in common bean (Haley et al., 1993; Miklas et al., 1993). Interspecific populations exploit the same concept to generate polymorphism for genetic mapping purposes (Paterson et al., 1990).

\section{RAPD MARKERS IN HORTICULTURAL CROPS}

PCR has been used successfully to identify RAPD markers linked to disease resistance genes in tomato, lettuce, and common bean. Martin et al. (1991) were the first to demonstrate the feasibility of using RAPD markers to tag the Pto gene, which confers resistance to Pseudomonas syringae pv. tomato in tomato. Michelmore et al. (1991) identified the first RAPD markers linked to the downy mildew resistance gene (Dm 5/8) in lettuce. Paran et al. (1991) have identified other RAPD markers linked to the $D m$ 1, 3, 4, 7, 13 genes. In common bean, Miklas et al. (1993) identified the first RAPD marker OA14 ${ }_{1100}$ tightly linked to the $U p$-2 rust resistance gene (no recombinants). Haley et al. (1993) identified the OF10 $0_{970}$ RAPD marker linked at $2.15 \mathrm{cM}$ from $B$ 190 and the OI19 $9_{460}$ marker tightly linked to the same $B-190$ rust resistance gene block (no recombinants), and the OK14 ${ }_{620}$ RAPD marker linked at $2.23 \mathrm{cM}$ from the $U r-3$ rust resistance gene (1994c). Young and Kelly (1994) tagged the Are anthracnose resistance gene with the OQ4 $4_{1440}$ RAPD marker (linked at $2.0 \mathrm{cM}$ ), while AdamBlodon et al. (1994) identified a second RAPD marker $\left(\mathrm{RoH}_{2} \mathrm{O}\right)$ linked at $0.5 \mathrm{cM}$ to the same gene.

\section{BREEDING STRATEGIES USING RAPDS}

Various breeding strategies have been employed for incorporating disease resistance. These strategies have involved the separate deployment of single gene resistance traits or the accumulation of multiple disease resistance traits into breeding lines. In many cases, resistance genes are lost in segregating populations derived from crosses with disease-susceptible lines since inadequate selection is practiced in plant breeding nurseries. Stavely et al. (1989) have indicated that obtaining stable rust resistance in common bean may necessitate pyramiding specific, broadly effective, resistance genes into traditional cultivars. The strategy of gene pyramiding is appealing when one considers that, in bean, the pyramid of the three rust resistance genes $U p-2$ with $B-190$ with $U r-3$ affords resistance to 63 of the 65 bean rust races characterized in the U.S. Dept. of Agriculture collection (Kelly et al., 1994). Only races 58 and 67 overcome the genes in this pyramid.

Schafer and Roelfs (1985) have provided support for gene pyramiding in spring wheat. No significant stem rust epidemic has occurred in North America since 1955 because contemporary spring wheat cultivars possess as many as six resistance genes. It is understandable that single resistance genes have not provided durable resistance to a highly variable rust pathogen, but a cultivar with four or five genes conditioning resistance to all races might remain resistant for many years if the gene-for-gene concept is valid. In common bean, breeders have the opportunity to exploit the complementation of Andean and Mesoamerican resistance genes and the partial duplication of different resistance genes from within the same gene pools. For example, the Andean $U p-2$ gene is complementary to the Mesoamerican $U r-3$ gene, while the Mesoamerican $B-190$ gene partially duplicates the action of the $U r-3$ gene when one considers the resistance to individual rust races that each confers.

\section{EPISTATIC INTERACTIONS}

In an effort to achieve these objectives, MAS offers the breeder a viable approach to developing cultivars with pyramided resistance genes (Stuber, 1991). The identification of RAPD markers tightly linked to resistance genes allows selection of the resistance gene indirectly since the expression of the molecular marker is not masked by epistatic interactions that occur between resistance genes. The current procedure of gene pyramiding is not practical for plant breeders because of the epistatic interaction between resistance genes. Since pyramiding requires that both epistatic and hypostatic genes be combined into a single genotype, breeders have no convenient way to select for the hypostatic gene without using multiple inoculations with different races or test-crosses with a susceptible genotype (Kelly et al., 1993). I have made three-way crosses to combine the three rust resistance genes (Up-2,Ur-3,B-190) into a single bean genotype, using linked RAPD markers to select for the three pyramided resistance sources. With the identification of additional markers linked to more broadly based rust resistance genes (Johnson et al., 1994) present in the U.S. plant introduction collection, more extensive gene pyramiding of these hypostatic genes is now possible. Gene pyramiding, using MAS, ensures the durability of those rust resistance genes that have been used extensively in bean breeding programs across the United States.

Currently, a similar situation exists in breeding for resistance to bean common mosaic virus (BCMV) in common bean. New temperature-insensitive, necrosis-inducing strains (NL 3, NL 8) of BCMV are pathogenic on the widely used $I$ gene resistance. As breeders incorporate the epistatic $b c-3$ resistance gene into a range of genotypes carrying the $I$ gene, the action of the $I$ gene is masked. This prevents breeders from distinguishing and selecting the more desirable $I b c-3$ recombinants from the single $b c-3$ genotypes. Using the OW $13_{690}$ 
marker linked to the $I$ gene, breeders can now select for the $I b c-3$ combination that affords pyramided resistance to all known strains of BCMV (Haley et al., 1994b).

\section{LINKAGE DISTANCES}

The distance between the marker and the resistance gene can dramatically affect the efficiency of MAS. Linkage to a trait of interest can vary depending on the populations studied. Differences in recombination distance facilitates mapping and genetic introgression across gene pools but becomes problematic when breeders are working with germplasm from similar genetic backgrounds. In common bean, RAPDs linked to genes introgressed from germplasm derived from a different gene pool appear to have lower recombinational frequencies and apparent tighter linkages than recombinational distances measured between the same linkage relationships present in genetic backgrounds from which the genes originated (Haley et al., 1994b). Genes from the Andean gene pool appear to exhibit tighter linkages with markers when measured in Middle American genetic backgrounds (Miklas et al., 1993). A similar trend has been observed with Middle American resistance genes in Andean backgrounds (Haley et al., 1993). However, the approach is confounded by RAPD markers that may be gene pool specific and of no value in selecting for the resistance gene in the same genetic background from which it originated. OA $14_{1100}$ could not be used for selection for the $U p-2$ Andean rust resistance gene in germplasm from the same gene pool. The value of the marker is restricted to the Middle American gene pool. This finding is in contrast to the RAPD $\left(\mathrm{OI} 19_{460}\right)$ linked to the Middle American $B-190$ gene where its use would be universal across all gene pools, regardless of origin of the resistance gene. The most desirable marker is one that retains the linkage with the resistance gene and is clearly expressed and functional across a broad range of genetic backgrounds. This feature has been demonstrated in beans for RAPD markers linked to the $U r-3$ rust resistance gene (Haley et al., 1994c) and the $I$ gene for BCMV resistance (Haley et al., 1994b); however, many studies are restricted to specific genetic populations and the usefulness of a linked marker is not demonstrated across a range of genotypes. Young and Kelly (unpublished data) showed that recombinational distances ranged from 2.0 to $5.5 \mathrm{cM}$ between two populations of common bean segregating for the Are anthracnose resistance gene and the OQ $4_{1440}$ RAPD marker. The apparent tight linkage observed in the inter-gene pool (wide) cross would suggest that linkage drag was restricting recombination in that cross but was less a factor in the related (intra-gene pool) cross. Linkage drag (Stam and Zeven, 1981; Zeven et al., 1983) between distantly related species overestimates levels of linkage in gene tagging and map construction (Paterson et al., 1990), resulting in markers that may be ineffective for many breeding programs that are restricted to within-species crosses. The application of a marker in breeding populations is more important to a plant breeder than the actual position of the marker in a genetic linkage map derived from a wide cross.

\section{SELECTION EFFICIENCY}

Efficiency of selection based on markers can be dramatically improved using a marker linked in repulsion with the resistance gene. A repulsion-phase marker is one linked with the susceptibility allele as compared with the more traditional marker linked in coupling with the resistance allele. Haley et al. (1994a) demonstrated that selection against a repulsion-phase RAPD provided a greater proportion of homozygous resistant genotypes and a lower proportion of both segregating and homozygous susceptible individuals than did selection for the coupling-phase RAPD. This was demonstrated for a recessive BCMV resistance gene $(b c-3)$ linked in coupling $(1.9 \mathrm{cM})$ with RAPD marker OAD19 ${ }_{690}$ and in repulsion $(7.1 \mathrm{cM})$ with RAPD marker OS13 ${ }_{660}$. Selection against a repulsion-phase marker linked at a 10-cM distance provided greater selection efficiency than 1-cM coupling-phase linkage, based on calculations of selection efficiency. This is particularly significant since recessive resistance genes require breeders to select against the heterozygous susceptible individuals. In addition, selection of individuals based on the phenotype of combined coupling and repulsion-phase RAPD markers was equivalent to selection based on a codominant marker (RFLP) and was identical to selection based on the repulsion-phase marker alone. Traditionally, work has focused on coupling-phase markers, but in terms of selection efficiency, these markers can be superseded by those linked in repulsion with the resistance gene. Breeders, in their search for markers, should put emphasis on markers linked with the disease susceptibility allele, since MAS for such a marker would be as efficient as selection based on codominant RFLPs in early segregating generations. However, coupling-phase markers are more useful in MAS used to quickly backcross a trait from an exotic source into an adapted line (Johnson et al., 1995). All possible $\mathrm{BC}_{n} \mathrm{~F}_{1}$ segregants useful as parents for the next cycle of backcrossing $(\mathrm{Rr})$ would carry the repulsion marker regardless of the level (generation) of backcrossing, while those with the resistance allele could be detected by a coupling-phase marker. Finally, selection based on linked RAPD markers can be as efficient as RFLP markers when used on advanced-generation recombinant inbred lines (RILs), where the level of heterozygosity is minimal. Delaying selection until later generations may be a desirable strategy, since dominant resistance genes would have a higher probability of being fixed at this stage.

\section{Use of recombinants to facilitate MAS}

In those instances where a linked marker is present in resistant and susceptible germplasm ( $U p-2$ gene in bean; Miklas et al., 1993), breeders could use recombinant individuals from the mapping population as parents in MAS for disease resistance. Within segregating mapping populations, a low frequency of recombinants is generally observed between the marker and resistance gene. Those recombinants that carry the resistance gene but not the marker can be used as parents to introgress the same resistance gene into susceptible genotypes that possess the marker. In this instance, selection against the marker (repulsion linkage) would be practiced to identify resistant individuals. This has been successfully demonstrated in common bean (Miklas, unpublished data) and affords the opportunity to use MAS in segregating germplasm, which, because of origin (gene pool), would be precluded from such studies. Selection against a marker would have increased efficiency (Haley et al., 1994a). A similar situation arises with repulsion-phase markers that could be converted to couplingphase markers by selecting as parents those recombinant individuals that are resistant but carry the marker. In this case, selection would be less efficient because the breeder is selecting for a marker linked in coupling.

\section{REPRODUCIBILITY}

Lack of reproducibility or reliability is not an unexpected problem with a new technology. Similar difficulties were originally encountered in the development of isozyme markers but were later eliminated. Problems with reliability have occurred in the development of RAPD markers (Weeden et al., 1992), but those laboratories that persisted with the technology have clearly demonstrated the consistent reproducibility of linked RAPDs over time and material (Haley et al., 1994c). Sources of variability lie in the choice of thermal-stable DNA polymerase and thermal cycler used in PCR amplification, or in imprecise matches between the short oligonucleotide primers (decamers) and the template DNA at the low annealing temperatures (35-40C) typical of these types of studies. Discrepancies between laboratories have been observed because of these variables. To address these concerns and those over map-based cloning, sequenced-characterized amplified regions (SCARs) have been developed by Kesseli et al. (1992) and Paran and Michelmore (1993) in lettuce. A similar marker described as allele-specific associated primers (ASAPs) has been developed by Weeden et al. (1992) in common bean. Reproducibility is increased by sequencing the two ends of the RAPD fragment and synthesizing two longer primers $(\approx 24$ base pairs $)$ homologous to each end. These two primers (ASAPs), which include the original decamer sequence, are used in the same PCR protocol, but at elevated annealing temperatures (50-65C), and generally produce a single fragment (SCAR) equivalent to that previously sequenced. Paran and 
Michelmore (1993) developed SCARs for eight RAPD markers linked to downy mildew $(\mathrm{Dm})$ resistance genes in lettuce, and Adam-Blondon et al. (1994) developed a SCAR linked to the anthracnose (Are) resistance gene in common bean. The majority of SCARs amplified single major bands the same size as the original RAPD fragment. Since only a single band is amplified, the electrophoretic step can be eliminated because the amplified DNA can be visualized easily by staining with ethidium bromide. The latter technique has been demonstrated successfully using ASAPs linked to photoperiod genes in common bean (Gu et al., 1994), and application of the technique to tagging resistance genes in common bean has been reported by Weeden (personal communication). The presence or absence of amplified DNA would similarly indicate presence or absence of the linked resistance gene. When screened on thermal cyclers adapted for microtiter plates, many samples can be screened quickly with limited personnel.

\section{SUMMARY}

Molecular markers can potentially increase the importance and usefulness of indirect selection in plant breeding. In the past, MAS was not widely practiced because of ineffective linkages or the relative inefficiency of selection for a marker due to either incomplete or masked expression or low heritability. Molecular markers are not replacements for classical resistance breeding techniques. They assist breeders in improving efficiency and permitting the successful pyramiding of resistance genes where epistasis is involved, thus improving durability of these resistance sources. RAPD markers provide a useful technology that afford breeders alternative approaches to breeding for durable resistance. The technology will add to the arsenal of tools available to the applied plant breeder active in disease resistance breeding. The opportunity to select for disease resistance in the absence of the pathogen opens new possibilities to breeders where either inexperience with a pathogen or quarantine regulations restricting its entry are major obstacles.

RAPD markers tightly linked to major resistance genes have been identified in various horticultural crops and will facilitate the development of more disease-resistant cultivars. The next advance in this technology, designed to overcome problems with reproducibility across laboratories, will be the development of sequence or allelespecific primers (SCARs, ASAPs) for a resistance gene once the original polymorphism has been identified using the random primers. The ASAP primers are longer in sequence and usually result in the amplification of a single band, which can eliminate the need for electrophoresis, thus making the identification simpler and more efficient. Selection for resistance genes linked to SCARs will be rapid and less expensive. MAS will become more valuable as additional markers linked to different resistance genes are identified in individual crops. The application of molecular markers to breeding represents an excellent example of the successful use of indirect selection for disease resistance.

\section{Literature Cited}

Adam-Blondon, A.F., M. Sévignac, H. Bannerot, and M. Dron. 1994. SCAR, RAPD and RFLP markers linked to a dominant gene (Are) conferring resistance to anthracnose in common bean. Theoretical Applied Genet. 88:865-870.

Afanador, L.K., S.D. Haley, and J.D. Kelly. 1993. Adoption of a 'mini-prep' DNA extraction method for RAPD marker analysis in common bean (Phaseolus vulgaris). Ann. Rpt. Bean Improvement Coop. 36:10-11.

Barone, A., E. Ritter, U. Schachtschabel, T. Debener, F. Salamini, and C. Gebhardt. 1990. Localization by restriction fragment length polymorphism mapping in potato of a major dominant gene conferring resistance to the potato cyst nematode Globodera rostochiensis. Mol. Gen. Genet. 224:177182.

Barua, U.M., K.J. Chalmers, C.A. Hackett, W.T.B. Thomas, W. Powell, and R. Waugh. 1993. Identification of RAPD marker linked to a Rhynchosporium secalis resistance locus in barley using near isogenic lines and bulked segregant analysis. Heredity 71:177-184.

Botstein, D., R.L. White, M. Skolnick, and R.W. Davis. 1980. Construction of a linkage map in man using restriction fragment length polymorphisms. Amer. J. Human Genet. 32:314-331.
Chaparro, J.X., D.J. Werner, D. O'Malley, and R.R. Sederoff. 1994. Targeted mapping and linkage analysis of morphological isozymes, and RAPD markers in peach. Theoretical Applied Genet. 87:805-815.

Degremont, I.V. and C.E. Vallejos. 1994. Isolation of markers tightly linked to a virus resistance gene ( $I$ ) of the common bean. Proc. Plant Genome II P41. p. 25.

Echt, C.S., L.A. Erdahl, and T.J. McCoy. 1992. Genetic segregation of random amplified polymorphic DNA in diploid cultivated alfalfa. Genome 35:8487.

Edwards, K.C., C. Johnstone, and C. Thompson. 1991. A simple and rapid method for the preparation of plant genomic DNA for PCR analysis. Nucleic Acids Res. 19:1349.

Foolad, M.R., R.A. Jones, and R.L. Rodriguez. 1993. RAPD markers for constructing intraspecific tomato genetic maps. Plant Cell Rpt. 12:293297.

Gepts, P. and F.A. Bliss. 1985. $\mathrm{F}_{1}$ hybrid weakness in the common bean. J. Hered. 76:447-450.

Gepts, P., T.C. Osborn, K. Rashka, and F.A. Bliss. 1986. Phaseolin protein variability in wild forms and landraces of the common bean (Phaseolus vulgaris): Evidence for multiple centers of domestication. Econ. Bot. 40:451-468.

Gu W.-K., N. Weeden, and D. Wallace. 1994. A technique adaptable to high sample number processing for marker assisted selection and other DNAbased screening applications. Proc. Plant Genome II P73. p. 33.

Haley, S.D., L.K. Afanador, and J.D. Kelly. 1994a. Selection for monogenic resistance traits with coupling- and repulsion-phase RAPD markers. Crop Sci. 34:1061-1066.

Haley, S.D., L. Afanador, and J.D. Kelly. 1994b. Identification and application of a random amplified polymorphic DNA marker for the I gene (potyvirus resistance) in common bean. Phytopathology 84:157-160.

Haley, S.D., L.K. Afanador, P.N. Miklas, J.R. Stavely, and J.D. Kelly. 1994c. Heterogeneous inbred populations are useful as sources of near-isogenic lines from RAPD marker localization. Theoretical Applied Genet. 88:337342.

Haley, S.D., P.N. Miklas, L. Afanador, and J.D. Kelly. 1994d. Random amplified polymorphic DNA (RAPD) marker variability between and within gene pools of common bean. J. Amer. Soc. Hort. Sci. 119:122-125.

Haley, S.D., P.N. Miklas, J.R. Stavely, J. Byrum, and J.D. Kelly. 1993. Identification of RAPD markers linked to a major rust resistance gene block in common bean. Theoretical Applied Genet. 86:505-512.

Hancock J.F., P.A. Callow, and D.V. Shaw. 1994. Randomly amplified polymorphic DNAs in the cultivated strawberry, Fragaria $\times$ ananassa. J. Amer. Soc. Hort. Sci. 119:862-864.

$\mathrm{Hu}$, J. and C.F. Quiros. 1991. Identification of broccoli and cauliflower cultivars with RAPD markers. Plant Cell Rpt. 10:505-511.

Johnson, E., P.N. Miklas, and J.R. Stavely. 1994. The potential of coupling and repulsion phase RAPD markers for indirect selection of rust resistance progeny in common bean. Ann. Rpt. Bean Improv. Coop. 37:81-82.

Johnson, E., P.N. Miklas, J.R. Stavely, and J.C. Martinez-Cruzado. 1995. Coupling and repulsion RAPD markers for marker-assisted selection of a rust resistance gene in common bean. Theoretical Applied Genet. (In press.)

Johnson, W.C. and P. Gepts. 1994. Two new molecular markers linked to bc3. Ann. Rpt. Bean Improvement Coop. 37:206-207.

Jung, G., D.P. Coyne, P.W. Skroch, J. Nienhuis, E. Arnaud-Santana, J. Bokosi, S.M. Kaeppler, and J.R. Steadman. 1994. Construction of a genetic linkage map and locations of common blight, rust resistance and pubescence loci in Phaseolus vulgaris L. using RAPD markers. Ann. Rpt. Bean Improvement Coop. 37:37-38.

Kelly, J.D., P.N. Miklas, J.R. Stavely, L. Afanador, and S.D. Haley. 1994. Application of RAPD markers for disease resistance breeding in beans. Ann. Rpt. Bean Improvement Coop. 37:15-16.

Kelly, J.D., J.R. Stavely, P. Miklas, L. Afanador, and S.D. Haley. 1993. Pyramiding rust resistance genes using RAPD markers. Ann. Rpt. Bean Improvement Coop. 36:166-167.

Kesseli, R.V., I. Paran, and R.W. Michelmore. 1992. Efficient mapping of specifically targeted genomic regions and the tagging of these regions with reliable PCR-based genetic markers. Crop Sci. Soc. Amer.-Amer. Soc. Hort. Sci.-Amer. Genet. Assn. Joint Plant Breeding Symp. Ser., Minneapolis. Crop Sci. Soc. Amer., Madison, Wis. p. 31-36.

Klein-Lankhorts R., P. Rietveld, R. Verkerk, R. Weide, C. Gebhardt, M. Koornneef, and P. Zabel. 1991a. RFLP markers linked to the root knot nematode resistance gene $M i$ in tomato. Theoretical Applied Genet. 81:661667.

Klein-Lankhorts, R.M., A. Vermunt, R. Weide, T. Liharska, and P. Zabel. 1991b. Isolation of molecular markers for tomato (L. esculentum) using random amplified polymorphic DNA (RAPD). Theoretical Applied Genet. 83:108-114.

Koller, B., A. Lehmann, J.M. McDermott, and C. Gessler. 1993. Identification 
of apple cultivars using RAPD markers. Theoretical Applied Genet. 85:904906.

Landry, B.S, R.V. Kesseli, B. Farrar, and R.W. Michelmore. 1987. A genetic map of lettuce (Lactuca sativa L.) with restriction fragment length polymorphism, isozyme, disease resistance and morphological markers. Genetics 116:331-337.

Martin, G.B., J.G.K. Williams, and S.D. Tanksley. 1991. Rapid identification of markers linked to a Pseudomonas resistance gene in tomato by using random primers and near-isogenic lines. Proc. Natl. Acad. Sci. USA 88:2336-2340.

McClean, P., J. Ewing, M. Lince, and K. Grafton. 1994. Development of a RAPD map of Phaseolus vulgaris L. Ann. Rpt. Bean Improvement Coop. 37:79-80.

Melchinger, A.E. 1990. Use of molecular markers in breeding for oligogenic disease resistance. Plant Breeding 104:1-19.

Michelmore, R.W., I. Paran, and R.V. Kesseli. 1991. Identification of markers linked to disease resistance genes by bulked segregant analysis: A rapid method to detect markers in specific genomic regions using segregating populations. Proc. Natl. Acad. Sci. USA 88:9828-9832.

Miklas, P.N., J.R. Stavely, and J.D. Kelly. 1993. Identification and potential use of a molecular marker for rust resistance in common bean. Theoretical Applied Genet. 85:745-749.

Mohan, M., S. Nair, J.S. Bentur, U.P. Rao, and J. Bennett. 1994. RFLP and RAPD mapping of the rice $G m 2$ gene that confers resistance to biotype 1 of gall midge (Orseolia oryzae). Theoretical Applied Genet. 87:782-788.

Nienhuis, J., T. Helentjaris, M. Slocum, B. Ruggero, and A. Schaefer. 1987. Restriction fragment length polymorphism analysis of loci associated with insect resistance in tomato. Crop Sci. 27:797-803.

Nodari, R.O., E.M.K. Koinange, J.D. Kelly, and P. Gepts. 1992. Towards an integrated linkage map of common bean. I. Development of genomic DNA probes and levels of restriction fragment length polymorphism. Theoretical Applied Genet. 84:186-192.

Nodari, R.O., S.M. Tsai, R.L. Gilbertson, and P. Gepts. 1993. Towards an integrated linkage map of common bean. 2. Development of an RFLPbased linkage map. Theoretical Applied Genet. 85:513-520.

Osborn, T.C., D.C. Alexander, and J.F. Fobes. 1987. Identification of restriction fragment length polymorphisms linked to genes controlling soluble solids content in tomato fruit. Theoretical Applied Genet. 73:350-356.

Paran, I., R.V. Kesseli, and R.W. Michelmore. 1991. Identification of restriction fragment length polymorphism and random amplified polymorhphic DNA markers linked to downy mildew resistance genes in lettuce, using near-isogenic lines. Genome 34:1021-1027.

Paran, I. and R.W. Michelmore. 1993. Development of reliable PCR-based markers linked to downy mildew resistance genes in lettuce. Theoretical Applied Genet. 85:985-993.

Paterson, A.H., J.W. DeVerna, B. Lanini, and S.D. Tanksley. 1990. Fine mapping of quantitative trait loci, using selected overlapping recombinant chromosomes, in an interspecific cross of tomato. Genetics 124:735-742.

Paterson, A.H., S.D. Tanksley, and M.E. Sorrells. 1991. DNA markers in plant improvement. Advances Agron. 46:39-90.

Penner, C.A., J. Chong, M. Levesque-Lemay, S.J. Molnar, and G. Fedak. 1993. Identification of a RAPD marker linked to oat stem rust gene $P g 3$. Theoretical Applied Genet. 85:702-705.

Ragot, M. and D.A. Hoisington. 1993. Molecular markers for plant breeding: Comparisons of RFLP and RAPD genotyping costs. Theoretical Applied Genet. 86:975-984.

Ritter, E., T. Debener, A. Barone, F. Salamini, and C. Gebhardt. 1991. RFLP mapping on potato chromosomes of two genes conferring resistance to potato virus X (PVX). Mol. Gen. Genet. 227:81-85.
Rowland, L.J. and A. Levi. 1994. RAPD-based genetic linkage map of blueberry derived from a cross between diploid species (Vaccinium darrowi and $V$. elliottii). Theoretical Applied Genet. 87:863-868.

Sarfatti, M., M.A. Abied, J. Katan, and D. Zamir. 1991. RFLP mapping of I1, a new locus in tomato conferring resistance against Fusarium oxysporum F. sp. lycopersici race 1. Theoretical Applied Genet. 82:22-26.

Schachermayr, G., H. Siedler, M.D. Gale, H. Winzeler, M. Winzeler, and B. Keller. 1994. Identification and localization of molecular markers linked to the $\operatorname{Lr} 9$ leaf rust resistance gene of wheat. Theoretical Applied Genet. $88: 110-115$.

Schafer, F.R. and A.P. Roelfs. 1985. Estimated relation between numbers of urediniospores of Puccinia graminis f. sp. tritici and rates of occurrence of virulence. Phytopathology 75:749-750.

Skroch, P., J. Tivang, and J. Nienhuis. 1992. Analysis of genetic relationships using RAPD marker data. Applications of RAPD technology to plant breeding. Crop Sci. Soc. Amer.-Amer. Soc. Hort. Sci--Amer. Genet. Assn. Joint Plant Breeding Symp. Ser., Minneapolis. Crop Sci. Soc. Amer., Madison, Wis. p. 26-30.

Stam, P. and A.C. Zeven. 1981. The theoretical proportion of the donor genome in near-isogenic lines of self-fertilizers bred by backcrossing. Euphytica 30:227-238.

Stavely, J.R., J.R. Steadman, and R.J. McMillian, Jr. 1989. New pathogenic variability in Uromyces appendiculatus in North America. Plant Dis. 73:428-432.

Stiles, J.I., C. Lemme, S. Sondur, M.B. Morshidi, and R. Manshardt. 1993. Using randomly amplified polymorphic DNA for evaluating genetic relationships among papaya cultivars. Theoretical Applied Genet. 85:697701.

Stuber, C.W. 1991. Biochemical and molecular markers in plant breeding. Plant Breeding Rev. 9:37-61.

Tanksley, S.D, R. Bernatzky, N.L. Lapitan, and J.P. Prince. 1988. Conservation of gene repertoire but not gene order in pepper and tomato. Proc. Natl. Acad. Sci. USA 85:6419-6423.

Tanksley, S.D. and T.J. Orton. 1983. Isozymes in plant genetics and breeding, Parts 1A and 1B. Elsevier, Amsterdam, Netherlands.

Wang, H., M. Qi, and A.J. Culter. 1993. A simple method of preparing plant samples for PCR. Nucleic Acids Res. 21:4153-4154.

Weeden, N.F., G.M. Timmerman, M. Hemmat, B.E. Kneen, and M.A. Lodhi. 1992. Inheritance and reliability of RAPD markers. Crop Sci. Soc. Amer.Amer. Soc. Hort. Sci.-Amer. Genet. Assn. Joint Plant Breeding Symp. Ser., Minneapolis. Crop Sci. Soc. Amer., Madison, Wis. p. 12-17.

Welsh, J. and M. McClelland. 1990. Fingerprinting genomes using PCR with arbitrary primers. Nucleic Acids Res. 18:7213-7218.

Williams, J.G.K., A.R. Kubelik, K.J. Livak, J.A. Rafalksi, and S.V. Tingey. 1990. DNA polymorphisms amplified by arbitrary primers are useful as genetic markers. Nucleic Acids Res. 18:6531-6535.

Williamson, V.M., J.-Y. Ho, F.F. Wu, N. Miller, and I. Kaloshian. 1994. A PCR-based marker tightly linked to the nematode resistance gene, $M i$, in tomato. Theoretical Applied Genet. 87:757-763.

Yang, X. and C. Quiros. 1993. Identification and classification of celery cultivars with RAPD markers. Theoretical Applied Genet. 86:205-212.

Young, N.D., D. Zamir, M.W. Ganal, and S.D. Tanksley. 1988. Use of isogenic lines and simultaneous probing to identify DNA markers tightly linked to the Tm-2a gene in tomato. Genetics 120:579-585.

Young, R.A. and J.D. Kelly. 1994. A RAPD marker for the $A R E$ anthracnose resistance gene in beans. Ann. Rpt. Bean Improvement Coop. 37:77-78.

Zeven, A.C., D.R. Knott, and R. Johnston. 1983. Investigation of linkage drag in near isogenic lines of wheat by testing for seedling reaction to races of stem rust, leaf rust and yellow rust. Euphytica 32:319-327. 


\title{
Classical and Molecular Approaches to Breeding Fruit and Nut Crops for Disease Resistance
}

\author{
Shawn A. Mehlenbacher \\ Department of Horticulture, Oregon State University, Agriculture and Life Sciences Building 4017, \\ Corvallis, OR 97331
}

Disease resistance is an objective of most plant breeding programs and fruit and nut crops are no exception. Classical methods have been used successfully to develop cultivars resistant to several major diseases, while the level of success with other pathogens has been less striking. Currently, there is considerable activity in developing linkage maps for these crops and in transformation. Marker-assisted selection (MAS) and transformation appear to be valuable additions to the tools available to develop new and better cultivars. This paper will review the current status of breeding fruit and nut crops for disease resistance. A few key diseases of the major fruit and nut crops and the methods used to identify resistant seedlings will be described. The current status of linkage mapping and transformation in these crops will be presented, and the application of these tools in developing diseaseresistant cultivars will be discussed.

Compared to the major field crops, comparatively little effort is devoted to fruit and nut crop improvement. Although several programs exist for strawberry (Fragaria $\times$ ananassa Duch.) and peach [Prunus persica (L.) Batsch.], the number of programs and full-time equivalents (FTE) devoted to the other fruit and nut crops is quite small. Yet, in spite of this, new cultivars of several crops, including strawberry, raspberry (Rubus spp.), blueberry (Vaccinium corymbosum L.), table grape (Vitis spp.), peach, and walnut (Juglans regia L.), have had considerable impact on their respective industries. Success with other crops has been less impressive. For many crops, breeding programs have been underway for a short time relative to the length of the breeding cycle. The long juvenile phase of tree crops limits the amount of genetic improvement per year, and the large plant size makes each increment of improvement expensive (Hansche, 1983). In addition, in wine grapes, apples (Malus $\times$ domestica Borkh.), and pears (Pyrus communis L.), industries have been built around a small number of selected cultivars with wide name recognition, and these industries are reluctant to change.

\section{A BREEDING PROGRAM FOR CLONALLY PROPAGATED CROPS}

In modern agriculture, fruit and nut cultivars are propagated asexually for commercial production, and the same breeding methods are used for all. Because the methods used for clonally propagated crops are quite different from those used to develop homozygous lines and $F_{1}$ hybrid varieties, much of the plant breeding and gene mapping literature is not applicable to fruit and nut crops. It is therefore appropriate to review the procedures used for clonally propagated crops.

Cultivars of fruit and nut crops are superior combinations of genes, and clonal propagation allows faithful reproduction of the superior genotype. In general, cultivars are highly heterozygous and inbreeding results in a decline in vigor and fertility, as is the case with naturally cross-pollinated crops. Deleterious recessive alleles are carried by the leading cultivars of many crops.

The first step in any breeding program is to define and prioritize the objectives. This step implies that genetic variation is present for each of the traits to be improved. If such variation is not known, germplasm must first be collected and evaluated. For each trait, a minimal acceptable standard should be established, and a reliable evaluation

Received for publication 20 Oct. 1994. Accepted for publication 17 Nov. 1994. Oregon Agricultural Experiment Station publication no. 10,594. The cost of publishing this paper was defrayed in part by the payment of page charges. Under postal regulations, this paper therefore must be hereby marked advertisement solely to indicate this fact. method should be available. Sometimes, an evaluation method must be developed before breeding for that objective can become routine.

The most common approach to breeding these crops is sometimes called "complementary hybridization." Poehlman (1987) presents a brief outline, and Simmonds (1979) discusses additional information. The parent clones of each cross are chosen such that the weaknesses of one are matched by the strengths of the other, with the hope that a few of their offspring will have the strengths of both parents and none of the weaknesses. Because the parent clones are highly heterozygous, tremendous segregation is apparent in the seedling population. The challenge then is to identify from among the thousands of seedlings the few that have potential as new cultivars. Evaluation typically is stepwise, with the number of selected genotypes decreasing in each step while the number of vegetatively propagated plants of each increases. In the first step, selection is based on the performance of the original seedling plant and is limited to highly heritable traits that can be evaluated quickly and inexpensively. In the second phase of evaluation, a small unreplicated trial is used to study the performance of selections more carefully. Typically, 10 plants of each selection are included. In the third stage of evaluation, advanced selections are grown in a replicated trial and compared to standard cultivars. Often, other breeders and a few progressive growers plant the best of these selections to see how they perform in their locations while yield trials are in progress. The very best selection is released as a new cultivar. For tree crops, selection is typically in only two phases to reduce the time for release of a new cultivar: evaluation of the original seedling and evaluation in a replicated trial. Janick et al. (1983) discussed procedures for releasing and legally protecting new cultivars.

Because the complementary hybridization approach is repeated generation after generation, the method is essentially phenotypic recurrent selection, with selected seedlings from one generation serving as parents of the next. Although only additive gene effects respond to selection over cycles, in any one generation, the breeder can take advantage of all types of genetic variance, because desirable gene combinations can be fixed by clonal propagation.

Plant breeding is a numbers game. Because the frequency of truly superior seedlings is quite low, breeders typically compensate by making as many crosses as the resources of the program allow. They grow a sample of seedlings from each cross sufficiently large to allow them to assess the potential of that cross. For example, the Oregon State Univ. (OSU), Corvallis, hazelnut (Corylus avellana L.) breeding program plants $\approx 5000$ new seedlings in the field each year. We average $\approx 50$ to 60 crosses each year and believe that 80 to 100 seedlings allow us to determine the potential of a cross. Selections that prove to be superior parents are crossed with additional genotypes.

A second approach, the modified backcross method, involves a series of crosses and is used to transfer a single trait from a wild or unadapted source to something with cultivar potential. In contrast to the backcross method as used for inbred lines, a different "recurrent parent" is used in each backcross generation to avoid inbreeding. A good illustration of this approach is the pedigree of the scab-resistant 'McShay' apple (Mehlenbacher et al., 1988). Another good example of the modified backcross method is the incorporation of the dayneutral character from Fragaria virginiana ssp. glauca Wats into modern California strawberry cultivars (Bringhurst et al., 1989). Because of the high degree of heterozygosity of any parent clone, it is not possible to recreate the same clone with one added gene using the backcross method. For agronomic and vegetable crops, the release of a backcross-derived cultivar typically involves five or six backcross generations. In fruit and nut crops, the number of generations is often considerably less. Half-high blueberries, for example, are first-genera- 
tion interspecific hybrids (Luby et al., 1986). 'Nova Easygro' apple, which combines scab resistance from the Russian selection R127407A with large fruit size, is the result of only two backcross generations (Crowe, 1975). 'Rouville' apple, which combines scab resistance from Malus atrosanguinea Schneid. 804 with large fruit size, is similarly the product of only two backcross generations (Rouselle and Fortin, 1983). The majority of almond [Prunus dulcis (Miller) D. A. Webb] cultivars are essentially selections from the wild. Following interspecific hybridization [e.g., with Prunus webbii (Spach) Vieh. and peach], selections with cultivar potential can be recovered after one or two backcrosses to P. dulcis Miller [T. Gradziel, personal communication (pers. comm.)]. At the other extreme, when gall mite (Cecidophyopsis ribis Westw.) resistance was transferred from gooseberry (Ribes grossularia L.) to black currant (R. nigrum L.), selections with cultivar potential were not recovered until the $\mathrm{BC}_{7}$ generation (Brennan et al., 1993).

In contrast to other crops, breeders of vegetatively propagated crops tend to view heterozygosity per se as desirable, and search out and use many diverse parents.

\section{DISEASE RESISTANCE}

Host plant resistance is an effective means of controlling many diseases and is a major component in disease management programs. As environmental concerns continue and as fewer pesticides are available for use on minor crops, resistant cultivars will become more important.

Disease resistance is an objective of most breeding programs, and Simmonds (1979) discusses the topic from a breeder's perspective. More accurately, disease resistance is one of many objectives. The pathogens that affect fruit and nut crops include fungi, bacteria, viruses, and mycoplasma-like organisms. Sources of resistance are known for many diseases but not for others. The severity of certain diseases varies from one region to another, and from year to year. The emphasis that a breeder places on disease resistance reflects its importance in that area. Classical disease resistance breeding has been most effective when it is a joint effort between a plant breeder and a plant pathologist. Unfortunately, close cooperation is the exception rather than the rule, and many plant breeders have found themselves working alone.

A seedling population segregating for resistance can be evaluated in the greenhouse, growth chamber, nursery, field, or even in vitro. Dayton et al. (1983) reviewed methods for fruit and nut crops. More reliable or more efficient methods are constantly being developed or refined. If disease resistance is a top priority, it becomes a primary screen and only resistant seedlings are planted in the field. For diseases that are less serious, a secondary screening of promising selections quantifies the level of resistance and this information is included in the release notice of the new cultivar. A high level of resistance is often not necessary, but extreme susceptibility to any pathogen can doom an otherwise outstanding cultivar (Simmonds, 1979).

Resistance can be evaluated in various ways, as the examples will illustrate. A knowledge of the pathogen and its life cycle is essential. In some applications, seedlings are artificially inoculated in the greenhouse or growth chamber under controlled conditions. In others, seedlings are exposed to inoculum under field conditions, where disease pressure and uniformity are hoped to be adequate to determine the level of resistance. In some cases, resistance can only be assessed in the field in certain "test years" when conditions are appropriate for disease development. In field trials, artificial inoculum is sometimes applied to supplement natural inoculum, and "spreader rows" of a susceptible cultivar can also be used to boost the natural level of inoculum.

Greenhouse and growth chamber tests have replaced field evaluation for disease resistance in many cases. They usually give more reliable, repeatable results and allow early elimination of susceptible seedlings. The development of these screening methods involves a knowledge of the "disease triangle" (Fig. 1). For disease to develop, a susceptible host, a virulent pathogen, and the appropriate environmental conditions must coincide. The conditions provided in these tests generally duplicate those that are ideal for disease development under

\section{The Disease Triangle}

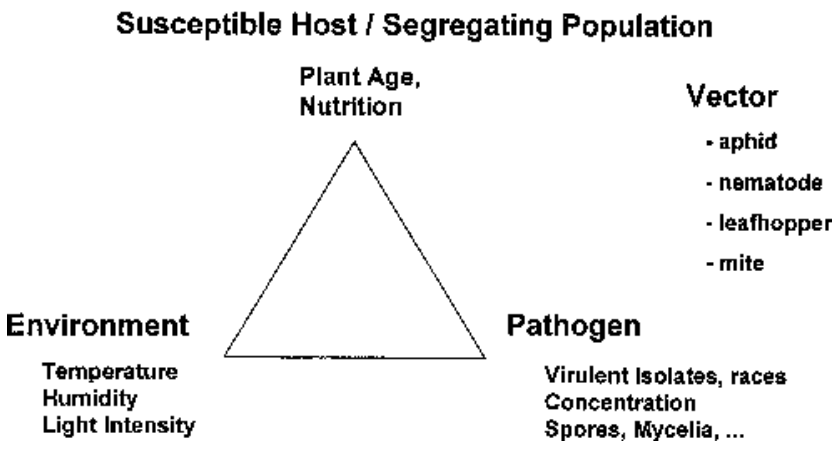

Fig. 1. The disease triangle. A susceptible host, a virulent pathogen, and appropriate environmental conditions must coincide for disease to develop. A vector also may be necessary.

natural conditions. The host plant must be at the appropriate growth stage and in reasonably good health. A virulent race or isolate of the pathogen must be present at an effective concentration and in the right form (spores, mycelia, etc.). Carborundum may be needed to abrade the leaf surface. The appropriate environmental conditions must be present for infection and symptom expression to occur; temperature and humidity often are critical factors. Symptom expression may occur hours, days, weeks, or even months after infection. For eastern filbert blight [Anisogramma anomala (Peck) E. Müller] of hazelnut, cankers do not develop until 15 months after infection (Stone et al., 1992).

Disease resistance is generally categorized as either vertical or horizontal (van der Plank, 1982), although not all plant-pathogen interactions fit nicely into either category. Vertical resistance genes in the host confer a high level of resistance that is often expressed as a hypersensitive response. In segregating populations, seedlings can be classified as either resistant or susceptible. There are often several races of the pathogen; the race can be identified by inoculating a series of cultivars called "differential hosts" that carry known resistance alleles. For diseases that have been studied extensively, a gene-forgene relationship between resistance genes in the host and virulence genes in the pathogen has been demonstrated (Sidhu, 1987). Vertical resistance genes are fairly simple to manipulate through breeding because segregation ratios can be predicted. Many vertical resistance genes have been transferred from wild or unadapted material using the modified backcross method. When a new race of the pathogen appears, the resistance is no longer effective. The development of new races is a concern primarily with rusts, mildews, and other air-borne fungi, as new races of these pathogens can spread quickly. Similarly, new biotypes of aphid vectors also can spread quickly. For soil-borne fungi, bacteria, and nematodes, spread is usually localized; thus, vertical resistance genes are more likely to provide long-term control (Simmonds, 1979) if precautions are taken to minimize spread by people.

In contrast to vertical resistance, horizontal resistance is under polygenic control. A segregating population typically shows a continuous distribution for disease reaction. Highly susceptible and highly resistant plants can be present, while most plants show an intermediate reaction. Resistance is often expressed as a slow rate of lesion development or reduced sporulation. The level of horizontal resistance in a population can be increased by recurrent selection in the absence of vertical resistance genes.

Both vertical and horizontal resistance have been used successfully by breeders. In fact, in practice it is not necessary to understand the mechanism of resistance. What is necessary is the presence of genetic variation for disease resistance and the ability to select for it (Simmonds, 1979).

Control of some diseases is more easily accomplished by breeding for resistance to the vector rather than to the pathogen itself. Examples of this approach include breeding for resistance to the raspberry aphid 
(Amphorophora idaei Börner in Europe and A. agathonica Hottes in North America) to control mosaic virus, breeding for resistance to the sharpnosed leafhopper (Staphytopius magdalensis Peoc.) to control blueberry stunt mycoplasma, and breeding for gall mite resistance in black currant to slow the spread of reversion virus. Many viruses are also nematode-vectored (e.g., fanleaf virus in grape, tomato ringspot in Prunus), and in these instances, nematode resistance might be more easily accomplished than virus resistance.

\section{CLASSICAL APPROACH TO BREEDING FOR DISEASE RESISTANCE}

\section{Small fruit}

Strawberry (Fragaria Xananassa Duch.). Virus tolerance is a requirement of cultivars on the West Coast. Four major viruses affect strawberry: strawberry mottle, strawberry crinkle, strawberry vein banding, and strawberry mild yellow edge. Disease pressure is particularly severe in British Columbia, where the susceptible cultivar Hood cannot be grown and where the virus tolerance of 'Totem' is a major factor in its long-term success (Daubeny et al., 1993). Virus tolerance is evaluated in the field in British Columbia. Under severe pressure, tolerant seedlings remain symptomless while susceptible seedlings show virus symptoms within 1 year of field planting.

Red stele, caused by Phytophthora fragariae Hickman, is a problem in most wet sites, although hill culture and other cultural practices can minimize its impact. Screening for red stele resistance is a major part of the programs at Corvallis and Beltsville, Md., and Scott et al. (1984) reviewed the programs' status and procedures. Resistance has been evaluated using benches in a cool greenhouse and inoculation with a mixture of isolates. High humidity and cool temperatures are critical, especially after inoculation. Testing procedures using growth chambers have been developed that allow screening on a year-round basis (John Maas and Gene Galletta, pers. comm.). Several races of the pathogen have been identified, and a gene-for-gene relationship between host and pathogen genes has been documented. A series of differential hosts with known resistance alleles is used to identify races of the fungus (van de Weg et al., 1993a, 1993b). It is critical that only pathogen-free plants be planted in the field to avoid spread of new races.

Other root-rot diseases that are a concern in the eastern United States include verticillium root rot (V. albo-atrum Reinke \& Berth. and $V$. dahliae Kleb.) and black root rot caused by Pythium and Rhizoctonia. Resistance to these pathogens is evaluated by planting seedlings and replicating yield trials in sites with heavy, wet, infested soils.

Foliar diseases that include leaf spot [Mycosporella fragariae (Schw.) Lind] and leaf scorch [Diplocarpon earliana (Ell. \& Ev.) Wolf] are also problems in the eastern United States and Canada. Some breeders select for resistance when the disease is present; in Quebec, seedlings are inoculated in the greenhouse and advanced selections are retested in the greenhouse (S. Khanizadeh, pers. comm). Resistance to fungal pests of strawberry are generally quantitative and partially dominant so that some resistance is transmitted in the first generation (Galletta, pers. comm.)

Anthracnose (Colletotrichum acutatum Simmonds) is a problem in the southern states where it affects plants and fruit (Ballington and Milholland, 1993). In Arkansas, resistant seedlings are selected in the field where inoculum is abundant and uniformly distributed (J.N. Moore, pers. comm.). Growth chamber inoculations have been used in North Carolina (Ballington and Milholland, 1993). Resistance is quantitative, with moderate narrow-sense and high broad-sense heritability (Gupton and Smith, 1991).

Raspberry and blackberry (Rubus spp.). Resistance to the mosaic virus complex that affects red raspberry has been very effectively accomplished by breeding for resistance to the raspberry aphid vector rather than to the viruses themselves. Keep (1989) reviewed the resistance sources and procedures used against the European raspberry aphid (Amphorophora idaei Börner). In the United Kingdom, four aphid biotypes are known, but some resistance genes confer resistance to all known biotypes. The same testing procedures are used in British Columbia for resistance to the North American raspberry aphid ( $A$. agathonica Hottes). Two years ago, a new biotype was discovered there that was able to overcome the resistance of recent introductions. However, resistance to the new biotype has been discovered in native Rubus idaeus var. strigosus, and it appears that collection and use of several resistance genes holds considerable promise for the future (Daubeny and Stary, 1982; Daubeny et al., 1992).

Resistance to root rot caused by Phytophthora fragariae var. rubi is an objective in the Pacific Northwest. The level of resistance in common cultivars, as determined by field tests, was reported by Barritt et al. (1979). Using greenhouse inoculations, Bristow et al. (1988) found resistance in the native North American raspberry Rubus idaeus var. strigosus Michx., particularly those accessions collected in wet sites, and also in the salmonberry Rubus spectabilis Pursch. Efforts are underway to incorporate these additional sources of resistance. Duncan et al. (1987) identified three races of the fungus, but all North American isolates were of race 3. Recent work was described by Kennedy and Duncan $(1991,1993)$.

Keep (1989) and Hall (1990) described sources of resistance to several other diseases and pests for red raspberry and for blackberry, respectively. Interspecific transfer of disease resistance is common in Rubus.

Blueberry (Vaccinium corymbosum L.). Several diseases affect blueberry. Two of the most severe in North Carolina are stem blight and blueberry stunt (Ballington et al., 1993). Other important diseases include stem canker caused by Botryosphaeria corticis (Demaree \& Wilcok) Arx \& Muller, anthracnose caused by Colletotricum gloeosporioides (Penz.) Penz \& Sacc., shoestring virus, red ringspot, mummy berry caused by Monilinia vaccinii-corymbosi (Reade) Honey, and leaf mottle virus.

Stem blight caused by Botryosphaeria dothidea (Mouq. ex Fr.) Ces $\&$ deNot. is especially severe on young plants when the fungus enters through pruning wounds. Creswell and Milholand (1987) and Cline et al. (1993) describe methods for evaluating cultivar susceptibility. While pure $V$. corymbosum appears to be uniformly susceptible, resistance appears to be present in $V$. angustifolium Ait. and $V$. ashei Reade. Resistance is quantitative, partially dominant, and sufficiently heritable so that response to phenotypic recurrent selection is expected. Many progenies must be grown to obtain resistant selections.

Breeding for resistance to the blueberry stunt mycoplasma is being conducted by breeding for resistance to the vector, the sharpnosed leafhopper, as there is no known source of resistance to the mycoplasma itself. Sources of resistance to feeding and oviposition have been identified (Etzel and Meyer, 1986; Meyer and Ballington, 1990). Resistance is a recessive trait in V. elliottii Chapman and a partially resistant trait in $V$. ashei.

Stem canker also is a serious problem in many production regions. Milholland and Galletta (1969) developed screening methods, and Ballington et al. (1993) have identified eight races to date. Propagation from canker-free sources and isolation of new plantings from old canker-infected plants is effective at minimizing disease incidence.

Red ringspot virus susceptibility was evaluated in New Jersey under field conditions. Degree of symptom expression after several years of field exposure indicates that resistance is polygenic and that 'Earliblue' and several numbered selections appear to transmit resistance (Ehlenfeldt et al., 1993).

Grape (Vitis spp. L.). Powdery mildew caused by Uncinula necator (Schwein.) Burr is a serious disease problem of both wine and table grapes in all production regions. Some American Vitis species and interspecific hybrids involving these species are resistant, as are numerous French hybrids with commercial value (Boubals, 1961). Resistance is an objective of breeding programs in New York (Cornell Univ., Geneva), Arkansas (Univ. of Arkansas), California [U.S. Dept of Agriculture (USDA) and SunWorld], and Minnesota (Univ. of Minnesota). As is the case with mildews in other crops, there is some controversy as to the reliability of screening very young seedlings in the greenhouse. Reliability increases with plant age. Both California programs eliminate a high percentage of seedlings based on greenhouse screening under shadecloth. Only highly resistant seedlings are planted and further evaluated in the vineyard. The high level of resistance of some French hybrids is being transferred to seedless table grapes, and in some cases, resistance may be due to a single dominant 
gene. In Arkansas, only highly susceptible seedlings are eliminated in the greenhouse; additional notes are recorded in the vineyard. In Minnesota, seedlings, $\approx 30 \mathrm{~cm}$ tall, are transplanted to an unsprayed nursery adjacent to an infested vineyard in May. Seedlings are rated for susceptibility from late July to September, and only resistant seedlings are transplanted to the vineyard the following spring. At Geneva, all seedlings are transplanted and grown in an unsprayed vineyard.

Other important grape diseases include black rot caused by Guignardia bidwellii (Ellis) Viala et Ravaz, downy mildew caused by Plasmopara viticola de Bary, and Pierce's disease caused by the bacterium Xylella fastidiosa. In general, seedlings are rated in unsprayed vineyards. Resistance is derived from native North American species (Alleweldt et al., 1991; Barrett, 1955; Jabco et al., 1985; Mortensen, 1968, 1977; Mortensen et al., 1977). Phylloxera and nematodes, including the dagger nematodes, which vector grape fanleaf virus, are serious pests, but no good screening methods have yet been developed.

\section{Tree fruit}

Apple (Malus $\times$ domestica Borkh.). Considerable effort has gone into breeding disease-resistant apples. Phytophthora crown rot and fire blight are the most serious diseases that affect rootstocks. Scab, cedarapple rust, powdery mildew, and fire blight are the four most serious diseases of scion cultivars.

The objectives, standards, and flow chart of the Geneva apple rootstock breeding program were described by Cummins and Aldwinckle (1983). Resistance to phytophthora crown rot caused by several Phytophthora spp. and fire blight are considered essential in new rootstock selections. Sequential inoculation with these two pathogens eliminates $90 \%$ of the seedlings. Phytophthora resistance screening is by flooding 10-day-old seedlings to the soil line with suspensions of zoospores of mixed pathogenic isolates. This inoculation results in foot and hypocotyl infections and death of susceptible seedlings (Aldwinckle and Cummins, 1974; Watkins and Werts, 1971).

Fire blight, caused by the bacterium Erwinia amylovora (Burr.) Winslow et al., is a serious problem of rootstocks and scions. Resistance is assessed in seedlings when they are 8 to 10 weeks old by injecting their shoot tips with $10^{6}$ to $10^{7}$ cells of a mixture of virulent isolates. Seedlings are discarded if lesions exceed $30 \%$ of the seedling's height. Reinoculation confirms their resistance. Gardner et al. (1980) demonstrated that the high level of resistance in $M . \times$ robusta (Carriere) Rehder No. 5 and M. ×sublobata (Dipp.) Rehder PI 286613 appeared to be oligogenic, and it is for these sources of resistance that differential response of bacterial isolates has been detected (Norelli et al., 1984). In scion cultivar breeding, resistance is polygenic and a mixture of isolates is used for inoculation.

The development of scion cultivars resistant to apple scab caused by Venturia inaequalis (Cke.) Wint. was summarized by Crosby et al. (1992). Subsequent research identified six loci for qualitative resistance, with dominant alleles $\mathrm{V}_{\mathrm{f}}, \mathrm{V}_{\mathrm{m}}, \mathrm{V}_{\mathrm{r}}, \mathrm{V}_{\mathrm{bj}}, \mathrm{V}_{\mathrm{b}}$, and $\mathrm{V}_{\mathrm{a}}$ designated according to their origin (Williams and Kuc, 1969). Of these, $V_{f}$ from Malus floribunda Siebold ex Van Houte 821 has been used most widely. 'Nova Easygro' and 'Nova Spy' carry $\mathrm{V}_{\mathrm{r}}$; 'Rouville' and four recent Russian releases carry $\mathrm{V}_{\mathrm{m}}$ and are thus susceptible to race 5 . Races of the scab fungus have been known for some time, and the recent discovery in Europe of a race able to overcome the $V_{f}$ gene (Parisi et al., 1993) is causing increased interest in other sources of resistance. If seedlings with a few sporulating lesions are classified as resistant, greenhouse inoculations of populations carrying the $V_{f}$ gene segregate 1 susceptible : 1 resistant. In the Geneva program, only seedlings with no sporulating lesions are kept.

Cedar-apple rustcaused by Gymnosporangiumjuniperi-virginianae Schw. is a problem in eastern North America where the eastern red cedar (Juniperus virginiana L.), the alternate host of the fungus, is present. Greenhouse inoculations are used in the Geneva program, and seedlings that show pycnia development are eliminated (Aldwinckle etal., 1977). Resistance is conferred by two dominant genes (Aldwinckle et al., 1977; Chen and Korban, 1987). When dominant alleles are present at both loci, pycnia formation is suppressed. In New Jersey, eastern red cedar trees are planted alongside apple seedlings and natural infection allows identification and elimination of the most susceptible seedlings.

A very high level of powdery mildew [caused by Podosphaera leucotricha (Ell. \& Ev.) Salm.] resistance has been reported in several small-fruited species (Dayton, 1977; Gallott et al., 1985; Knight and Alston, 1969; Korban and Dayton, 1983), and for these sources, it is possible to screen young seedlings in the greenhouse. Many of these sources appear to carry single dominant genes for resistance. Most apple breeders, however, have preferred to use the polygenic resistance present in several apple cultivars. Resistant cultivars tend to transmit resistance, and ratings of potential parents give a good indication of their value as parents (Brown, 1959). However, greenhouse inoculations are not considered reliable for evaluating polygenic resistance. Many breeders eliminate highly susceptible seedlings in the nursery, while others wait until they are growing in the field (Mihatch and Mildenberger, 1967).

Fruit rots [bitter rot caused by Glomorella cingulata (Ston.) Spauld. \& Schrenk and black rot caused by Botryosphaeria obtusa (Schw.) Cke.] are problems in the southern United States. Evaluation methods, which will be used to search for sources of resistance, are being developed at the Univ. of Arkansas. Sooty blotch and flyspeck are diseases for which there are no good sources of resistance.

Pear. Fire blight resistance is an objective of both the Kearneysville, W.Va., and Harrow, Ont., pear breeding programs (Hunter, 1993). The inoculation procedures are the same as for apple. In greenhouse tests, seedlings in which $>30 \%$ of the shoot length becomes infected are eliminated. In the field, injections of shoot tips with bacteria can supplement natural pressure for blossom and shoot blight. Resistance is quantitatively inherited with a narrow sense heritability of $52 \%$ and is not associated with poor fruit quality (Bell et al., 1976). Subsequent research in Italy and France has confirmed these results (Bagnara et al., 1993, 1994), and this seems to be the case regardless of the source of resistance (Layne et al., 1968). A few pear genotypes transmit a high degree of susceptibility and are believed to carry a dominant gene for sensitivity (Thompson et al., 1975). Several resistant cultivars have been released from both the Kearneysville and the Harrow programs. No differential response of isolates has been reported (Bell et al., 1990; Hunter and Bonn, 1994).

Peach (Prunus persica L.) Batsch. Bacterial spot caused by Xanthomonas campestris pv. pruni is a problem common to the eastern states and is evaluated by planting seedlings and selections in the field (Werner et al., 1986). Several alternative methods have been proposed, including greenhouse inoculations, detached leaf tests, and others (Civerolo and Keil, 1976; Daines and Hough, 1951; Hammerschlag, 1988; Randhawa and Civerolo, 1985), but breeders have declined to use them because they are not sufficiently reliable or worth the effort.

Brown rot caused by Monilinia fructicola (Wint.) Honey is a problem in most areas and is particularly severe on clingstone peaches and nectarines. Not much resistance is available in cultivars. Brown rot resistance from the Brazilian cultivar Bolinha is being used in the cling peach programs at the Univ. of California-Davis and the Univ. of Arkansas. Resistance appears to be limited to the skin, as the disease spreads quickly if the skin is punctured (T. Gradziel and J.N. Moore, pers. comm.). Fruit susceptibility is evaluated by placing a drop of spores on the skin and measuring the diameter of the developing lesion.

Canker caused by Cytospora leucostoma (Pers.) Sacc. is a problem in northern areas, particularly those with fluctuating temperatures in midwinter. Results using the wound-freeze method developed by Scorza and Pusey (1984) appear to correlate well with field observations. Resistance has been reported in 'Yennoh', 'NJC1', and 'Encore' (Chang et al., 1989).

Apricot (Prunus armeniaca L.). Bacterial spot is also a problem in apricot, and resistance is similarly based on field observations during epiphytotics. Layne (1966) noted that leaves and fruit can have different levels of resistance.

Plum pox or sharka virus is a serious problem in Europe. Based on field observations, cultivars are known to vary in severity of symptom expression (Dosba et al., 1991).

Sour cherry (Prunus cerasus L.). Cultivars differ in their susceptibility to cherry leaf spot caused by Blumeriella jaapii (Rehm) Arx. Artificial inoculation procedures can be used to identify the most 
susceptible seedlings and cultivars (Sjulin, 1989). At Michigan State Univ., greenhouse inoculations are used to eliminate the most susceptible seedlings (A. Iezzoni, pers. comm.)

Plum (Prunus salicina Lindl). Japanese plums encounter few problems in the major production area of California, but several diseases attack them in the humid southeastern United States. Resistance to most fungal diseases is rated based on survival and health in field plantings. Plum leaf scald caused by Xylella fastidiosa Wells et al. is of increasing concern in Florida, Georgia, and Alabama (Sherman et al., 1989, 1992). Plum pox virus is a severe problem of hexaploid cultivars in Europe. Bacterial spot causes lesions on leaves and fruit, and cankers on twigs. Evaluation methods are described by Topp et al. (1991, 1993a, 1993b).

Citrus. Disease problems of citrus are primarily rootstock problems. Soost and Cameron (1975) described evaluation methods for phytophthora root rot, citrus tristeza virus (CTV), and nematodes. Sweet orange trees on sour orange rootstocks frequently show quick decline when infected by CTV (Garnsey, 1985). The trifoliate orange, Poncirus trifoliata (L.) Raf., is resistant to CTV and transmits resistance to some hybrid progeny. Poncirus also has been the primary source of resistance to Phytophthora in intergeneric hybrids (Gmitter et al., 1992). In addition, it is resistant to citrus nematode, Tylenchulus semipenetrans Cobb (Barrett, 1985).

\section{Tree nuts}

Walnut (Juglans regia $L$.). Blackline disease is a serious problem in California, where most orchards consist of Persian scion cultivars (Juglans regia) grafted to either northern California black walnut $[J$. hindsii (Jeps.) Rehder] or 'Paradox' hybrid (J. hindsii $\times$ J. regia) rootstocks. Blackline also has been observed in Europe (McGranahan and Catlin, 1987). Briefly, blackline is caused by the cherry leaf roll virus (CLRV), to which the Persian walnut is tolerant but J. hindsii and 'Paradox' are hypersensitive. The pollen-borne virus enters through flowers during pollination and spreads systemically in the tolerant scion. When the virus meets the hypersensitive rootstock, a layer of cells dies, leading to a "black line" at the graft union. The hypersensitive response of $J$. hindsii, J. major (Torr. ex Sitsgr.) Heller, and the eastern black walnut (J. nigra) is conferred by a single dominant gene (Dosba et al., 1989; Dosba and Germain, 1993; Mircetich and Rowhani, 1984). Two approaches are being followed in California and France. The first is the development of vigorous, tolerant clonal rootstocks and the other is the development of resistant scion cultivars by transferring the hypersensitive response of the black walnut by backcrossing.

In both approaches (rootstock and scion), segregating populations are evaluated to determine which selections are hypersensitive and which are tolerant. This determination can be made in 1 year. Persian rootstocks are grafted with scions of the selections in question, and the rootstocks are inoculated with CLRV using a bark patch graft. If a black line develops at the graft union, the scion is considered hypersensitive. If no black line develops and enzyme-linked immunosorbent assay reveals that the scion is infected, the selection is considered tolerant. Several vigorous, tolerant rootstock clones [(J. nigra $\times J$. regia $) \times J$. regia and (J. major $\times J$. regia $) \times J$. regia] that are late-leafing and have strong apical dominance are currently being tested in Bordeaux, France, and no further crosses are planned (Germain et al., 1994). The long-term backcrossing programs to develop hypersensitive scion cultivars are now in the $\mathrm{BC}_{3}$ generation and already the seedlings resemble wild populations of $J$. regia. They differ from leading cultivars mainly in shell thickness. The California program is using the $J$. hindsii source of hypersensitivity, while the French program is using the J. nigra and J. major sources. One or perhaps two more generations of backcrossing will be needed to recover thinshelled seedlings with cultivar potential. If the virus overcomes the resistance, then both scion and rootstock will be tolerant.

Bacterial blight caused by Xanthomonas campestris pv. juglandis is a problem in France and California. Late-leafing cultivars often escape blight and late-leafing is a priority trait in both programs, but nuts of these selections also are late-maturing. Field notes are taken on leaves and young fruit in early July and again in mid-August when infected, necrotic nuts drop. Shoots are inspected for cankers during winter. As disease escape is common, more stringent tests have been developed for assessing resistance.

Woeste et al. (1992) described inoculation and rating procedures for leaves and nuts, and detected differences in leaf symptoms and nut abscission. A more elaborate protocol is used in France where the disease is more severe (E. Germain, pers. comm.). Three trees of each selection are planted at a spacing of $1.5 \times 2.0 \mathrm{~m}$ under a mist system installed $2 \mathrm{~m}$ above ground level. For each tree, two nozzles $50 \mathrm{~cm}$ on either side of the tree emit 70 liters. $\mathrm{h}^{-1}$. Leaves and shoots are inoculated with a bacterial suspension (one completely colonized petri dish per liter of distilled water) at the end of the day to avoid hot, dry periods at the beginning of the second season in the field when shoots are 15 to $20 \mathrm{~cm}$ long. For the next 10 to 12 days, the mist is on $24 \mathrm{sec}$ every $20 \mathrm{~min}$ (to runoff) from 9:00 AM to 5:00 PM. Symptoms are noted 1 month after inoculation, and again 1 month later. Shoots are inspected for the presence of cankers after leaf fall. The inoculations are repeated a second year to verify the results. 'Adams 10' (resistant), 'Franquette' (intermediate), and 'Hartley' (susceptible) are included as the check cultivars.

Hazelnut (Corylus avellana L.). Eastern filbert blight caused by Anisogramma anomala (Peck) E. Müller is a serious disease that threatens Oregon's hazelnut industry. Its history, symptoms, and life cycle were reviewed by Mehlenbacher et al. (1994). Although pruning and chemicals slow the spread of the disease, genetic resistance offers the best long-term solution to the problem. Two sources of resistance are being used in the OSU hazelnut breeding program: immunity from 'Gasaway' and horizontal resistance within C. avellana. A high level of resistance was recently detected in several Corylus species (Coyne and Mehlenbacher, 1994) and will be incorporated in future crosses.

The old pollinizer cultivar Gasaway is heterozygous for a single dominant gene that confers immunity (Mehlenbacher et al., 1991), but it has many undesirable traits as well. A modified backcross program is being used to combine immunity with acceptable nut characteristics. Seedlings from the first backcross generation have begun to fruit. It appears that an immune selection with acceptable precocity, yield, and kernel quality will be obtained from the $\mathrm{BC}_{1}$ generation.

Standard cultivars vary in their level of susceptibility, and this variability can be quantified by counting the number and length of cankers that develop following exposure of potted trees under wooden frames topped with infected wood (Pinkerton et al., 1993).

Pecan [Carya illinoinensis (Wangenh) K. Koch]. Scab caused by Cladosporium caryigenum (Ell. et Lang.) Gottwald is the most serious disease of pecan. An unusually wet year resulted in scab infection in the USDA pecan breeding plots in Brownwood and College Station, Texas, in 1993 and allowed leaf and fruit infection to be rated on 33,000 seedlings and their parents. Heritability of resistance was estimated to be 54\% (Thompson and Grauke, 1994). The frequency of highly resistant cultivars and selections was low, but $\approx 20$ highly resistant genotypes with good nut quality were identified. The resistance appears to have been contributed by several unrelated parents. Advanced selections from the USDA program are being evaluated for susceptibility in Florida.

\section{MAPPING AND MAS}

Introductory comments. Molecular markers, including isozymes and DNA markers [restriction fragment length polymorphisms (RFLPs), random amplified polymorphic DNA (RAPDs), and others], have been useful in many situations relevant to applied plant breeding. Dendrograms constructed from molecular marker data indicate the degree of similarity of species and accessions and in general agree well with classifications based on morphological traits or geographic origin. Linkage maps have been constructed for many economically important crops, and maps for related crops have been compared when these maps have been constructed with common markers (e.g., Bonierbale et al., 1988). Most computer programs used for linkage map construction are designed for use with self-pollinated crops in which the parents are homozygous inbred lines. Recombination percentages are estimated from recombinant inbred lines or segregating $\mathrm{F}_{2}$ or $\mathrm{BC}_{1}$ seedling populations. These programs have been directly useful in less polymorphic crops (e.g., peach and citrus) in which the 
mapping populations have been generated in a two-step procedure. In the first step, highly heterozygous $F_{1}$ hybrids are obtained from wide crosses (often interspecific, or even intergeneric in the case of Citrus). The mapping population is produced by either selfing an $\mathrm{F}_{1}$ plant or backcrossing it to one of the parents. Data from these segregating $\mathrm{F}_{2}$ or $\mathrm{BC}_{1}$ populations are suitable for analysis with these standard programs. A concern in the use of wide crosses in the construction of linkage maps is that the amount of recombination between linked loci in these crosses may be considerably less than in crosses within the species of interest.

For most clonally propagated crops, however, parent clones are highly heterozygous and a tremendous amount of segregation can be observed in the first-generation intraspecific offspring, and simultaneous segregation of many loci allows linkage map construction. Procedures for map construction in this "double pseudotestcross" situation were described by Hemmat et al. (1994). Briefly, most loci will segregate $1: 1$, allowing construction of a linkage map for each parent of the cross. Loci that segregate 3:1 allow the maps for the two parents to be aligned.

Fruit and nut crops have additional advantages in mapping and molecular marker research. Their perennial nature allows use of the same plants over a period of years, during which many additional markers can be placed on the map. Clonal propagation allows several laboratories to use the same mapping populations in their research. The European tree-fruit mapping projects, which involve six laboratories in four countries, are using the same populations at all sites.

$M A S$. The identification of markers or "tags" tightly linked to genes of interest makes it possible to select for desired alleles indirectly. MAS appears to have promise in the development of disease-resistant cultivars. Suggested uses of molecular tags in fruit and nut breeding include: following resistance alleles in several crosses over several generations, identifying seedlings likely to be resistant in the absence of the pathogen, constructing pyramids of resistance genes without the need for progeny testing, and more rapidly eliminating the donor parent genome in a modified backcross program.

Some traits that show a continuous distribution in a segregating population may actually be controlled by a small number of loci (Paterson et al., 1991), and genetic analysis using molecular markers in conjunction with a linkage map can, in these instances, allow identification of the number and location of these loci. Bulk segregant analysis using extreme phenotypes (typically the upper and lower 5\%) is a powerful tool for identifying the number of major loci controlling the trait, although this procedure overestimates the effects of the identified loci (Lander and Botstein, 1989; Michelmore et al., 1991). If the number of quantitative trait loci (QTLs) is small (1-3), the trait can be handled as if it were qualitative. However, the application of MAS for yield and other traits that are truly quantitative is unclear (Dudley, 1993). In all cases, there is concern about the usefulness of molecular markers in different populations and the expression of alleles when transferred from one genetic background to another. MAS will supplement but not replace traditional breeding methods, and will likely be most useful for traits that are controlled by few loci and that are either expensive or difficult to evaluate by classical methods (Lande, 1992). For some pathogens, it may be difficult to provide conditions that provide uniform infection for precise screening-but such conditions must be provided when identifying marker loci. Theoretically, MAS is superior to conventional methods if the fraction of the additive variance explained by the markers exceeds the narrow sense heritability of the trait (Dudley, 1993). However, most traits in fruit and nut crops are highly heritable (Hansche, 1983).

\section{Mapping and MAS in small fruit}

In strawberry, a map has been constructed in a diploid population at the Univ. of New Hampshire (Davis, 1993). The map contains 80 markers, most of which are RAPDs. It is not yet known how useful this map will be for working at the octoploid level, but researchers hope that "tags" can be developed for red stele resistance genes in cooperation with the USDA Small Fruits Laboratory in Beltsville.

In blueberry, a map constructed from a diploid population was recently published (Rowland and Levi, 1994). The map contains $>70$ markers, most of which are RAPDs. Michigan State Univ. researchers are using markers on this map to locate resistance to shoestring virus in a tetraploid population (J. Hancock, pers. comm.). A cooperative project is also underway in North Carolina and New Jersey to find markers for resistance to the sharpnosed leafhopper with an emphasis on the rabbiteye blueberry source (J. Ballington, pers. comm.).

A linkage map for grape was recently constructed at Geneva (B. Reisch, pers. comm.). The map contains 500 markers, most of which are RAPDs, and was constructed from a population of complex parentage: (Vitis rupestris $\times V$. cineria) $\times V$. vinifera. One of the markers is closely linked to a powdery mildew resistance locus. Several other populations in an unsprayed vineyard are segregating for resistance to powdery and downy mildew and black rot, and the search for molecular markers linked to alleles for resistance to these three diseases is in progress. North American species carry genes for resistance to the major diseases and pests. Because grape species intercross freely, a great wealth of genetic diversity is available for mapping and use in future breeding. At the Univ. of California-Davis, the objective of the grape rootstock breeding program is to develop rootstocks resistant to phylloxera, fanleaf virus, and several species of nematodes. The lack of reliable screening methods for these pests currently is a serious limitation.

\section{Mapping and MAS in tree fruit}

A linkage map for apple was recently published (Hemmat et al., 1994) and research is in progress in Europe. In subsequent work at Geneva, N.Y., markers for fruit color and mildew immunity have been located in the 'Rome Beauty' $x$ 'White Angel' cross, and markers for scab resistance genes $\left(V_{f}\right.$ and $V_{r}$ ) and columnar growth habit have been identified in other populations (Conner et al., 1994; Cheng et al., 1994, Hemmat et al., 1994; N. Weeden, pers. comm.). Durham and Korban (1994) discovered a marker for a minor gene for scab resistance from M. floribunda 821. The recent report of a race of scab able to overcome the $V_{f}$ resistance gene (Parisi et al., 1993) indicates that single-gene resistance is unlikely to be durable. Pyramids of $V_{f}$ and other genes will likely be incorporated in future cultivars, and MAS will facilitate the identification of seedlings carrying multiple resistance alleles. With the recent map-based cloning of a disease resistance gene in tomato (Martin et al., 1993), breeders hope that map-based cloning of resistance genes also will be possible in apple in the next few years. Once cloned, these resistance genes could then be inserted into otherwise superior but susceptible cultivars.

Stone fruit. The European Prunus mapping project began in Fall 1993 and is a 4-year project involving six research institutes in four countries. In the first phase, $\mathrm{F}_{2}$ populations from crosses of 'Earlygold' peach $x$ 'Texas' almond and 'Stella' $x$ a cherry species are being used to construct a basic map of 200 RFLP markers (Arús et al., 1994). Then, 11 progenies (four of peach, three of cherry, two of almond, and two of plum) will be used to assign important traits to the overall map. To my knowledge, no mapping work is in progress in North America for sweet cherry, sour cherry, or apricot.

With its small genome size and large number of simply inherited traits, peach is a logical choice for genetics studies. A linkage map for peach was recently published for a North Carolina $F_{2}$ population segregating for many morphological and isozyme traits (Chaparro et al., 1994). The map contains 85 loci (mostly RAPDs), including markers for nectarine skin, red leaf pigmentation, and upright (pillar) growth habit. Isozyme studies have shown that peach has fewer polymorphisms than other tree fruit (Byrne, 1990). Plans at North Carolina State Univ. (NCSU) include mapping genes for bacterial spot resistance in an $\mathrm{F}_{2}$ population from a cross of the highly susceptible 'O'Henry' with resistant 'Sentinel', and a continuation of the search for markers near the nectarine locus. A linkage map for peach also has been developed at Clemson Univ. using populations from USDA (Kearneysville), NCSU, and Institut National de la Recherche Agronomique (Bordeaux, France). Their map currently contains $\approx 60$ markers (40RFLPs, 15RAPDs, and 5 morphological traits) (Rajapakse et al., 1994; V. Baird, pers. comm.). Only $\approx 20 \%$ of the markers are polymorphic in all of the crosses investigated. The USDA Fruit Laboratory, Kearneysville, is interested in mapping genes associated 
with fruit quality. Applications of such markers would be for quick recovery of acceptable fruit quality (recurrent parent phenotype) when introgressing disease resistance genes from almond, wild peach species, or inferior cultivars (R. Scorza, pers. comm.).

A linkage map for an $\mathrm{F}_{2}$ interspecific population (dwarf peach 54P455 x 'Padre' almond) has been constructed at Univ. of CaliforniaDavis (Foolad et al., 1994). To date, $\approx 100$ RFLP markers have been assigned to nine linkage groups, six of which are large. Current research efforts involve bulk segregant analysis to assign important traits to the map (F. Bliss, pers. comm.). Possible applications include breeding for nematode resistance (root knot, ring, lesion, and dagger) because testing is time-consuming and difficult.

Citrus fruit. There is considerable activity in mapping and searching for molecular markers linked to important traits in citrus with an emphasis on rootstock diseases and pests. In the Florida and Univ. of California-Riverside programs, the trifoliate orange has been a source of many desirable traits. These traits include resistance to CTV, Phytophthora, and the citrus nematode. Two linkage maps were recently constructed using RFLPs (Durham et al., 1992; Jarrell et al., 1992) for a backcross population, and subsequent work with RAPDs has increased the number of loci to between 200 and 300. Resistance to tristeza virus appears to be conferred by a single dominant gene, and markers closely linked to resistance have been identified in both programs (F. Gmitter and M. Roose, pers. comm.). Research in Florida showed that resistance to the citrus nematode, expressed as the number of nematodes per gram fresh weight of root, showed a continuous distribution. However, when the most resistant and most susceptible individuals in the population were used in bulk segregant analysis, a marker linked to a major gene associated with resistance was identified (Ling et al., 1994). Researchers at Univ. of California-Riverside plan to map resistance to Phytophthora, but the lack of precise and repeatable methods for assessing resistance is a major stumbling block. Additional applications of MAS in citrus include mapping genes for growth habit and cold and salt stress from the trifoliate orange. Markers could also assist in more rapid recovery of acceptable fruit quality in backcrosses to cultivated types. Following hybridization with Poncirus, marginally edible fruit can be obtained in the third backcross generation.

\section{Mapping and MAS in nut crops}

Almond. Researchers in Spain have constructed a map for the almond cross 'Ferragnes' $x$ 'Tuono' (Arús et al., 1994). At present, it contains 150 markers (124 RFLPs, 15 RAPDs, and 7 isozymes) and is based on a population of 60 seedlings. Seedlings in this population are being evaluated for self-compatibility, bloom date, and percentage of double kernels. The workers hope that markers will be identified for these traits. Bulk segregant analysis in two other almond populations revealed one RAPD marker linked to the bitter kernel trait but none linked to self-compatibility. In an 'Earlygold' peach $\mathrm{x}$ 'Texas' almond $\mathrm{F}_{2}$ population, 50 markers already have been assigned and the map is now being expanded to 250 markers (Arús et al., 1994). This map and the similar peach $\mathrm{x}$ almond map developed at the Univ. of CaliforniaDavis likely will be applicable to both peach and almond and facilitate the transfer of useful genes, such as self-fertility from peach to almond and Cytospora canker resistance from almond to peach. Since selffertility in almond includes self-compatibility as well as flower structures that encourage self-pollination, self-fertility cannot be considered a single-gene trait. Almond cultivars are not far removed from the wild and thus only a few backcross generations should be necessary to recover cultivar potential (T. Gradziel, pers. comm.).

A linkage map for walnut was recently constructed using RFLP markers in a $(\mathrm{J}$. hindsii $\times \mathrm{J}$. regia $) \times J$. regia backcross population of 63 seedlings (Fjellstrom and Parfitt, 1994). Woeste et al. (1994) identified 60 RAPD markers specific to the black walnut in this cross in the hope that they would be useful in recovering "English" types quickly in backcrosses to transfer CLRV resistance to J. regia. A marker linked to the dominant gene for CLRV hypersensitivity also was identified (G. McGranahan, pers. comm.). Precocity, however, is of overriding importance in determining which seedlings are used as parents of the next backcross generation.
To my knowledge, there is currently no mapping work in progress for hazelnut, but research is in progress to identify RAPD markers linked to the dominant gene from 'Gasaway' for immunity to eastern filbert blight. Bulk segregant analysis is being used in a population segregating 1:1 for resistance and susceptibility. Detection of a RAPD marker closely linked to immunity would allow quick elimination of susceptible seedlings.

In pistachio, a RAPD marker linked to sex expression was reported recently (Hormaza et al., 1994).

\section{Appropriate uses and cost-effectiveness of MAS}

Clearly, considerable effort is being devoted to developing linkage maps for fruit and nut crops and in identifying molecular markers linked to traits of economic importance. MAS will be most useful for traits controlled by few loci; application of MAS for improving traits that are truly quantitative is in doubt (Dudley, 1993); The extent to which MAS will be used in practice depends on relative cost and expected return compared to conventional methods (Dudley, 1993), and application will, at least initially, be limited to simply inherited traits that are difficult or expensive to measure. Also, it is essential that the identified markers be useful in several crosses over several generations rather than to the one cross already evaluated. The following applications in breeding disease-resistant fruit and nut cultivars appear most appropriate: 1) identifying seedlings likely to be resistant either in the absence of the pathogen (due to quarantine regulations in some instances) or when reliable conventional methods are difficult or expensive, 2) constructing pyramids of resistance genes without the need for progeny testing (if multiple races of the pathogen exist), and 3) more rapidly eliminating the donor parent genome in a modified backcross program. The routine application of MAS requires careful analysis of the relative costs and benefits of the conventional and MAS approaches.

\section{TRANSFORMATION}

Transformation, the insertion of a foreign gene into a plant cell, is a powerful tool in the struggle to develop disease-resistant plant cultivars. The inserted genes can originate from viruses, bacteria, fungi, animals, other plant species, or the same crop species. Inserted genes can be sense or antisense constructs. Much progress has been made in the last few years, as reviewed by Fisk and Dandekar (1994), Hammerschlag and Litz (1992), Martin (1994), and Schuerman and Dandekar (1994). Agrobacterium-mediated transformation has been used most commonly, largely because of its efficiency. In most cases, our inability to regenerate plants from single cells is the limiting factor. In other cases, selecting transformed cells or killing Agrobacterium with antibiotics has a detrimental effect on cell survival. Transformation via particle bombardment also is being used. The frequency of stable transformation is generally lower than with Agrobacterium, and although the need for regeneration may be circumvented if meristems are the target tissue, the likelihood of recovering chimeras needs to be addressed. The number of known genes that confer disease resistance in higher plants is still limited but growing steadily. Likewise, the number of tissue-specific promoters is limited but also increasing.

Transformed cells are most often selected by incorporating antibiotic resistance. When exposed to the antibiotic, untransformed cells die and transformed cells survive and multiply. The neomycin phosphotransferase (NPTII) gene, which confers kanamycin resistance, is most commonly used. Also commonly incorporated is the gus gene, which encodes $B$-glucuronidase and allows its detection and assessment of expression patterns.

In many crops, regeneration has been possible only with seed- or seedling-derived material, as woody plants are particularly recalcitrant. Transformation of seedlings allows incorporation of genes from other organisms and greatly expands the opportunities for genetic improvement of plants. Since seedlings are nearly always inferior to their parent clones, further breeding would generally be needed to recover genotypes with cultivar potential. Although transformation of seedlings would allow incorporating new genetic material in the development of new cultivars, it would have a negligible impact on the 
time required for release of a new cultivar. For fruit crops that are sold by cultivar name (e.g., apple, pear, and wine grape), transformation would be a much more powerful tool if we were able to add one or a few genes to correct the deficiencies of otherwise excellent cultivars. In crops where transformation of clonal selections is possible, regeneration procedures have been genotype-specific. Even when clonal selections are transformed, field testing is essential to verify that the desired trait is expressed and that unintended changes have not occurred.

Expression in transgenic plants may be affected by many factors, including the construct, the number of insertions, the location of the insertion(s), and the promoter. Somaclonal variation also may result from in vitro culture. In a conventional breeding program, gene transfer via controlled pollination is a minor part of the overall program; evaluation of the resulting seedlings is the time-consuming part. Claims of the speed with which new cultivars can be developed by transformation imply that neither field evaluation nor propagation are needed before introducing a new cultivar; such exaggerated claims are unfortunately numerous in the popular press and in refereed publications.

The public is still apprehensive about the products of genetic engineering. Dozens of field tests of transgenic plants are now in progress and one product, the Flavr-Savr tomato, is now on the market. It will be interesting to see how well this product is accepted. Some publicity is needed to get a new cultivar off to a good start, and the Flavr-Savr tomato has had its share of attention. In the end, the marketplace will decide if the addition of one gene to a cultivar justifies tripling the price of the product. Breeders have long operated under the assumption that the worth of a new cultivar depends on the combination of traits that it expresses, not on the breeding method used in its development.

\section{Transformation-Small fruit}

Transformation of some strawberry cultivars is now routine, but procedures must be developed for each cultivar (R. Martin, pers. comm.) In British Columbia, the transformation work is for resistance to strawberry mild yellow edge virus. Some private companies are attempting to insert genes that confer resistance to other viruses. Transformation work is also in progress in several other locations (Haymes and Davis, 1993; James et al., 1990; Nehra et al., 1990; Nehra and Wallin, 1992). Transformation of red raspberry has been accomplished (Hassan et al., 1993), and research is underway at Agritope (Cohen et al., 1994; Mathews et al., 1994) and in England (Graham et al., 1990) to improve the efficiency of transformation. Black currant also has been transformed (Graham and McNicol, 1991). Research is underway at Beltsville and at Michigan State Univ. to transform blueberry, but efforts to date have not been successful (J. Hancock, pers. comm.). Transgenic cranberry (Vaccinium macrocarpon Aiton) plants have been produced by particle bombardment (Serres et al., 1992).

Embryogenic cultures of the grape cultivar Chancellor have been transformed using the biolistic method (Hebert et al., 1993). In transformed lines, the gus gene has been stably expressed in $>50$ plants for two years after bombardment (B. Reisch, pers. comm.). This work is now being expanded to include a Trichoderma endochitinase gene that confers fungal resistance. A cooperative effort between USDA labs in Kearneysville and Fresno, Calif., successfully transformed somatic embryos from zygotic embryos of a seedless $X$ seedless cross using a combination of the biolistic method and Agrobacterium. Bombardment with uncoated gold particles wounded the tissue, which was followed by cocultivation with Agrobacterium (Scorza et al., 1994a). Fourteen kanamycin-resistant plants with expressed gus were recovered. It should be possible to transform grape clones from somatic embryos using recently developed regeneration methods. Some transformation work with fanleaf virus coat protein is ongoing in France, and additional research is in progress in Israel. In grape, somatic embryos appear to arise from single cells on the tissue surface, and recent progress in regeneration is expected to allow transformation of superior clones (Emershad and Ramming, 1994). Baribault et al. (1990) and Mullins et al. (1990) also reported grape transformation.

\section{Transformation-Tree fruit}

Transformation work in apple at Cornell Univ. has emphasized fire blight resistance conferred by lytic peptides from the giant silk moth. The clonal rootstock M.26 has been transformed (125 lines) with the attacin gene. Transformed plants were resistant in greenhouse tests using bacterial injections with a hypodermic needle and are now growing in the field. The scion cultivar Gala also has been transformed, and 20 lines are now being evaluated. Transformation work is now being expanded to include chitinase genes from Trichoderma that confer resistance to fungi and the coat protein gene of tomato ringspot virus. Cultivars other than Gala are being transformed. Transformation of 'McIntosh' with antisense constructs for polygalacturonase and ACC synthase also is planned. The transformation system in apple is well developed using primarily Agrobacterium and some particle bombardment. Work at Univ. of California-Davis has produced apple lines that carry the insect resistance genes from Bacillus thuringiensis (A. M. Dandekar, pers. comm.), and research is in progress in Illinois to transform apple with the coat protein of apple mosaic virus. Additional work was described by James et al. (1989, 1994), and DeBondt et al. (1994).

Pear has not yet been successfully transformed, although success was recently reported for quince (Cydonia oblonga L.) rootstocks (Bunnag et al., 1994). Regeneration is difficult for most cultivars. The USDA laboratory in Kearneysville and the Geneva station are planning a cooperative effort to transform pears with the attacin gene which confers resistance to fire blight (R. Bell, pers. comm.).

There are several successful reports of transformation of peach (Scorza et al., 1995). All have used seeds or seedling-derived explants. More effective methods are needed to kill the Agrobacterium without harming the transformed plant tissue. Hammerschlag and Smigocki (1994) inserted a cytokinin biosynthesis gene into peach using a previously published protocol (Hammerschlag et al., 1989; Smigocki and Hammerschlag, 1991). Ye et al. (1994) used particle bombardment to transform callus tissue, but no transformed plantlets were recovered. Researchers at Kearneysville plan to bombard meristems in vitro either with or without subsequent cocultivation with Agrobacterium. Transformation of 'Nemaguard', 'Nemared', and 'Flordaguard' rootstocks with the coat protein of the tomato ringspot virus, the cause of stem pitting, is in progress. These rootstocks are seedpropagated, so transformation of individual clones is not necessary.

Austrian researchers have transformed apricot seedlings with the coat protein of the plum pox virus (Laimer et al., 1992).

Plum was recently transformed at Kearneysville using seed hypocotyl explants (Mante et al., 1991; Scorza et al., 1994b). Four plants carrying the papaya ringspot virus coat protein gene and 10 with the plum pox coat protein gene have been regenerated. Papaya ringspot virus is closely related to plum pox virus, which is the primary concern in stone fruit. Of the first four transformants, one expressed resistance or tolerance in greenhouse testing. The other 10 transformants are currently being tested. In the future, this research will be expanded to include tomato ringspot virus.

Transformation research in citrus has emphasized coat proteinmediated resistance to tristeza virus in rootstocks and scions (Moore et al., 1992, 1993). Transformation of nucellar seedlings of sour orange using Agrobacterium has been successful in Florida, and the resulting plants will soon be evaluated for virus resistance. Durability of virus resistance is a concern in all tree crops. Recent results with particle bombardment are encouraging (F. Gmitter, pers. comm.). Nucellar seedlings faithfully reproduce superior clones, but the resulting trees are juvenile. Transformation of adult tissue would be highly desirable, but inability to regenerate adult tissues is a major obstacle.

Among tropical tree fruits, much work has been done in papaya (Carica papaya L.) to insert the coat protein gene of papaya ringspot virus (PRV) using particle bombardment. Regenerated transgenic plants showed a range of reactions to PRV (Fitch et al., 1990; Tennant et al., 1994).

\section{Transformation-Tree nuts}

Walnut can now be transformed routinely using seed-derived 
somatic embryos (McGranahan et al., 1988, 1990). Lines transformed with the coat protein gene from CLRV were not hypersensitive to the virus. Rootability genes from Agrobacterium rhizogenes have been inserted, and one tree from this work is now growing in the lathhouse. Transgenic plants expressing insecticidal proteins from Bacillus thuringiensis have been produced and show resistance to the navel orangeworm (Amyelois transitella Walker) (Dandekar et al., 1994). Plans include transformation of Paradox rootstock with a $B t$ gene that confers nematode resistance, and possibly chitinase and other genes for resistance to fungal pathogens (McGranahan, pers. comm.). Pecan was recently transformed using the walnut somatic embryo protocols (McGranahan et al., 1993).

To my knowledge, there are no reports of successful transformation of hazelnut, although regeneration from somatic embryos is possible from seed-derived material (Perez et al., 1983; Rodriguez et al., 1989). Recently at OSU, three clones were regenerated from petioles or leaf disks (Yu, 1993). These results indicate that transformation and regeneration should be possible in the near future.

\section{Comments}

In several fruit crops (e.g., apple, pear, wine grape), industries have been built around a few cultivars. In these cases, traditional methods have had little impact, as the industry is reluctant to adopt new cultivars. The ability to insert one or a few genes to correct the deficiencies of the leading cultivars would be particularly attractive. The chief limitation of the backcross method in self-pollinated crops (as well as its greatest strength) is its predictability. This would also be the case with transformation in clonally propagated crops, as it would allow insertion of one gene to correct a deficiency in an otherwise good cultivar. This feature is also a limitation, because there would be no other improvements.

If we accept 'Delicious' as the ultimate apple, then transformation alone might be sufficient for improving the crop. However, the rapid acceptance of new apple cultivars from New Zealand and Japan demonstrates that improvements in quality are possible with traditional methods and that customers are willing to pay more for superior quality. Thus, it appears that, even for apple, transformation alone would be too conservative an approach for genetic improvement.

Several concerns are familiar to those working on transformation (and in fact all areas of research), yet the tendency not to publish negative results makes the public unaware of their existence. Many attempts to transform crop plants have failed. Many transformed lines do not express the trait that was sought, and many transformed lines express the inserted gene but are sufficiently abnormal to prevent them from being commercially acceptable; rarely is the latter discussed in the literature (Belknap et al., 1994). Abnormalities are often attributed to somaclonal variation from the tissue culture process, the site of gene insertion, the number of copies inserted, etc. Yet researchers (W.G. Dougherty, pers. comm.) working with tobacco at OSU and with apple at Geneva (H.S. Aldwinckle, pers. comm.) believe strongly that these abnormalities are due to the constructs themselves. That is, regardless of the number of copies inserted or their location, a construct always produces the same abnormal phenotype. As with traditional plant breeding, transformation also may be a "numbers game" that requires the use of several constructs and regeneration of several lines from each to find one that expresses the desired trait at a high level yet has no other adverse effects. Experienced researchers estimate that 50 to 100 transformed lines must be regenerated using several different constructs to be reasonably sure of obtaining at least one that meets the objectives of the program. Screening, multiplication, and field testing are the time-consuming phases.

Durability, breadth of protection, and stability also are concerns. Because tree fruit and nut crops are particularly long-lived, resistance must protect an orchard for several decades. If several races of the pathogen are known, resistance should be provided against all races in the area. Research is in progress to investigate the effect of a sexual cycle on stability using the gus gene in plum (R. Scorza, pers. comm.).

With tree crops, needs are different for rootstocks than for scion cultivars. Resistance to soil-borne fungi and viruses are needed in new rootstocks. With certain precautions, these pathogens do not move quickly; thus, single dominant gene resistance likely will provide sufficiently durable resistance. Growers change scion cultivars much more readily than they do rootstocks.

Concern for human safety has prompted the U.S. Food and Drug Administration (FDA) to require approval of each transgenic event. Transgenic rootstocks should be less controversial, as rootstocks are not consumed. Field testing of transgenic walnuts requires that the trees be emasculated each year and that all fruit be bagged on the tree before maturity. There also is some controversy about virus-resistant plants actually allowing recombination and thus the creation of new races of the pathogen (Greene and Allison, 1994).

Over time, we will learn how and when to best use these tools in conjunction with traditional breeding methods, as well as which health, safety, and environmental concerns are justifiable.

\section{CONCLUDING COMMENTS}

Disease resistance is an important objective of most fruit and nut crop breeding programs, as these crops are affected by a wide array of pathogens whose importance varies over locations and time. Each breeding program appropriately has unique objectives, priorities, and standards of acceptability. In some cases, a high level of resistance is required, while in other cases a moderate level is adequate. Extreme susceptibility to any pathogen is unacceptable. For some diseases, sources of resistance and methods of quickly and reliably identifying resistant seedlings are well documented and currently in use. This is not the case for other diseases. In a few instances, disease control has resulted from breeding for resistance to the vector rather than to the pathogen. Breeders are using vertical and horizontal resistance, and a few pathogen-host plant interactions show a gene-for-gene relationship. Many resistant cultivars have been developed by classical methods and released in spite of this difficulty.

Marker-assisted selection and transformation are new and powerful tools in the development of new disease-resistant cultivars. In spite of their "minor crop" status, fruit and nut crops have received considerable attention in both areas. These tools complement, but do not replace, classical plant breeding. Bulk segregant analysis appears to offer great potential for finding RAPD markers linked to alleles for disease resistance, even for traits that initially appear to be quantitative. Once molecular "tags" have been identified for resistance alleles, selection based on these tags becomes possible. However, feasibility and cost-effectiveness also must be considered, particularly when use of these tools involves a shift of resources away from traditional breeding rather than the use of supplemental resources for these additional activities.

The productive life of a new planting and the useful life of a new cultivar are also important considerations. For strawberry and other crops in which plantings are of short duration, resistance that delays disease development by a few weeks might be important. However, orchards of tree crops are often productive for several decades, and durable disease resistance is essential. The life expectancy of a new cultivar also varies markedly among crops. A strawberry cultivar might be obsolete a decade after release, while a new apple rootstock might be in the early stages of adoption by the industry at that time. Most peach cultivars also are short-lived; rarely is the same cultivar planted when an old orchard is removed. For crops in which the life expectancy of a new cultivar is short, a heavy reliance on transformation of currently important clones would be unwise, as those cultivars might well be obsolete by the time adequate field testing of the transformants had been accomplished.

As an applied plant breeder, my mission is to develop new and improved cultivars that meet the needs of the industry I serve and, indirectly, those of the public at large. The promotion of biotechnology at the expense of traditional plant breeding over the past several years has been detrimental to all concerned, as it is only by working together that we will be able to realize the full potential of all of the available tools. The greatest strides in past efforts to develop disease-resistant cultivars have been made by plant breeders and plant pathologists working together. In the future, a team effort should include a molecular geneticist as well. Such a team could discuss the needs of the industries, the strengths and weaknesses of current cultivars, the 
genetic resources available to meet those needs, and the evaluation methods available. They could then use the genes and the tools that are most appropriate and cost-effective in that situation.

\section{Literature Cited}

Aldwinckle, H.S. and J.N. Cummins. 1974. Familial differences in reaction to flood inoculation of young apple seedlings by zoospore suspension of Phytophthora cactorum. Proc. 19th Intl. Hort. Congr., Warsaw 1A:328.

Aldwinckle, H.S., R.C. Lamb, and H.L. Gustafson. 1977. Nature and inheritance of resistance to Gymnosporangium juniperi-virginianae in apple cultivars. Phytopathology 67:259-266.

Alleweldt, G., P. Spiegel-Roy, and B. Reisch. 1991. Grapes (Vitis) In: J.N. Moore and J.R. Ballington, Jr. (eds.). Genetic resources of temperate fruit and nut crops. Acta Hort. 290:291-337.

Arús, P., R. Messeguer, M. Viruel, K. Tobutt, E. Dirlewanger, F. Santi, R. Quarta, and E. Ritter. 1994. The European Prunus mapping projectProgress in the almond linkage map. Euphytica 77:97-100.

Bagnara, G.L., L. Rivalta, M. Laghi, and R. Quarta. 1994. Relationship between fire blight resistance and some traits in pear. Acta Hort. 367:2226.

Bagnara, G.L., L. Rivalta, M. Laghi, R. Quarta, and P. Lecomte. 1993. Cross combinations for fire blight resistance in pear. Acta Hort. 338:369-374.

Ballington, J.R. and R.D. Milholland. 1993. Screening strawberries for resistance to Colletotrichum acutatum in North Carolina. Acta Hort. 348:442448.

Ballington, J.R., S.O. Rooks, R.O. Milholland, W.O. Cline, and J.R. Meyer. 1993. Breeding blueberries for pest resistance in North Carolina. Acta Hort. 346:87-94.

Baribault, T.J., K.G.M. Skene, P.A. Cain, and N.S. Scott. 1990. Transgenic grapevines: Regeneration of shoots expressing B-glucuronidase. J. Expt. Bot. 41:1045-1049.

Barrett, H.C. 1955. Black rot resistance of the foliage on seedlings in selected grape progenies. Proc. Amer. Soc. Hort. Sci. 66:220-224.

Barrett, H.C. 1985. Hybridization of Citrus and related genera. Fruit Var. J. 39:11-16.

Barritt, B.H., P.C. Crandall, and P.R. Bristow. 1979. Breeding for root rot resistance in red raspberry. J. Amer. Soc. Hort. Sci. 104:92-94.

Belknap, W.R., D. Corsini, J.J. Pavek, G.W. Snyder, D.R. Rockhold, and M.E. Vayda. 1994. Field performance of transgenic Russet Burbank and Lemhi Russet potatoes. Amer. Potato J. 71:285-296.

Bell, R.L., J. Janick, R.H.Zimmerman, and T. van der Zwet. 1976. Relationship between fire blight resistance and fruit quality in pear. HortScience 11:500502.

Bell, R.L., T. van der Zwet, W.G. Bonn, B. Thibault, and P. Lecomte. 1990. Environmental and strain effects on screening for fire blight resistance. Acta Hort. 273:343-353.

Bonierbale, M.W., R.L. Plaisted., and S.D. Tanksley. 1988. RFLP maps based on a common set of clones reveal modes of chromosomal evolution in potato and tomato. Genetics 120:1095-1103.

Boubals, D. 1961. Étude des causes de la resistance des vitacées à l'oidium de la vigne-Uncinula necator (Schw.) Burr.-et de leur mode de transmission héréditaire. Ann. Amélioration Plantes 11:401-500.

Brennan, R.M., P.G. Lanham, and R.J. McNicol. 1993. Ribes breeding and research in the UK. Acta Hort. 352:267-275.

Bringhurst, R.S., H. Ahmadi, and V. Voth. 1989. Inheritance of the day-neutral trait in strawberries. Acta Hort. 265:35-41.

Bristow, P.R., H.A. Daubeny, T.M. Sjulin, H.S. Pepin, and G.E. Windom. 1988. Evaluation of Rubus germplasm for reaction to root rot caused by Phytophthora erythroseptica. J. Amer. Soc. Hort. Sci. 113:588-591.

Brown, A.G. 1959. The inheritance of mildew resistance in progenies of the cultivated apple. Euphytica 8:81-88.

Bunnag, S., R.C. Martin, D.W.S. Mok, and M.C. Mok. 1994. Towards genetic transformation of quince and pear. HortScience 29:561. (Abstr.)

Byrne, D.H. 1990. Isozyme variability in four diploid stone fruits compared with other woody perennial plants. J. Hered. 81:68-71.

Chang, L.S., A. Iezzoni, G. Adams, and G.S. Howell. 1989. Leucostoma persoonii tolerance and cold hardiness among diverse peach genotypes. J. Amer. Soc. Hort. Sci. 114:482-485.

Chaparro, J.X., D.J. Werner, D. O'Malley, and R.R. Sederoff. 1994. Targeted mapping and linkage analysis of morphological, isozyme, and RAPD markers in peach. Theor. Appl. Genet. 87:805-815.

Chen, H. and S.S. Korban. 1987. Genetic variability and the inheritance of resistance to cedar-apple rust in apple. Plant Pathol. 36:168-174.

Cheng, F., N. Weeden, and S. Brown. 1994. Molecular markers for fruit color in apple (Malus Xdomestica). HortScience 29:529. (Abstr.)

Civerolo, E.L. and H.L. Keil. 1976. Evaluation of Prunus spp. resistance to Xanthomonas pruni by artificial inoculation. Fruit Var. J. 30:17-18.
Cline, W., S. Rooks, R. Milholland, and J. Ballington. 1993. Techniques in breeding for resistance to blueberry stem-blight caused by Botryosphaeria dothidea. Acta Hort. 346:107-110.

Cohen, C., H. Mathews, V. Dewey, and R. Bestwick. 1994. Efficient plant regeneration from leaf and petiole explants in red raspberry. HortScience 29:514. (Abstr.)

Conner, P.J., S.K. Brown, and N.F. Weeden. 1994. Examination of quantitative trait loci in apple (Malus $\times$ domestica) using molecular markers. HortScience 29:529. (Abstr.)

Coyne, C.J. and S.A. Mehlenbacher. 1994. Resistance to eastern filbert blight in Corylus species and interspecific hybrids. HortScience 29:506. (Abstr.)

Creswell, T.C. and R.D. Milholland. 1987. Responses of blueberry genotypes to infection by Botryosphaeria dothidea. Plant Dis. 71:710-713.

Crosby, J.A., J. Janick, P.C. Pecknold, S.S. Korban, P.A. O'Connor, S.M. Ries, J. Goffreda, and A. Voordeckers. 1992. Breeding apples for scab resistance: 1945-1990. Fruit Var. J. 46:145-166.

Crowe, A.D. 1975. 'Nova Easygro' apple. Fruit Var. J. 29:76.

Cummins, J.N. and H.S. Aldwinckle. 1983. Breeding apple rootstocks. Plant Breeding Rev. 1:294-394.

Daines, R.H. and L.F. Hough. 1951. Artificial inoculation of peach seedlings with Xanthomonas pruni. Phytopathology 41:8-9. (Abstr.)

Dandekar, A.M., G.H. McGranahan, P.V. Vail, S.L. Uratsu, C.A. Leslie, and J.S. Tebbets. 1994. Low levels of expression of wild type Bacillus thuringiensis var. kurstaki cry1A (c) sequences in transgenic walnut somatic embryos. Plant Sci. 96:151-162.

Daubeny, H., F.J. Lawrence, and P.P. Moore. 1993. ‘Totem’ strawberry. Fruit Var. J. 47:182-184.

Daubeny, H., H.S. Pepin, and C.A. Levesque. 1992. Breeding for resistance to aphids and root rot in red raspberry. Acta Hort. 317:187-190.

Daubeny, H.A. and D. Stary. 1982. Identification of resistance to Amphorophora agathonica in the native North American red raspberry. J. Amer. Soc. Hort. Sci. 107:593-597.

Davis, T.M. 1993. Genetic mapping of the diploid strawberry using random amplified polymorphic DNA(RAPD) markers. Acta Hort. 348:439. (Abstr.)

Dayton, D.F. 1977. Genetic immunity to apple mildew incited by Podosphaera leucotricha. HortScience 12:225-226.

Dayton, D.F., R.L. Bell, and E.B. Williams. 1983. Disease resistance, p. 189215. In: J.N. Moore and J. Janick (eds.). Methods in fruit breeding. Purdue Univ. Press, West Lafayette, Ind

DeBondt, A., K. Eggermont, and W.F. Broekaert. 1994. Transgenic apple plants obtained by Agrobacterium-mediated gene transfer. Abstr. Fourth Intl. Congr. Plant Mol. Biol., Amsterdam, 19-24 June 1994. (Abstr.)

Dosba, F., F. Denise, P. Maison, G. Massonie, and J.M Audergon. 1991. Plum pox virus resistance of apricot. Acta Hort. 293:569-579.

Dosba, F. and E. Germain. 1993. Behaviour of the progeny of Juglans interspecific hybrids towards cherry leaf roll virus (CLRV). Acta Hort. 311:68-72.

Dosba, F., B. Nguyen, K. Mazy, and E. Germain. 1989. Etude dans le genre Juglans de different combinasions heterospecifique pour leur comportement vis-a-vis du cherry leaf roll virus (CLRV). Proc. 2nd colloque noyernoisetier, Programme de recherche agrimed, Bordeaux, France, 6-7 Sept. 1988. p. 3-16.

Dudley, J.W. 1993. Molecular markers in plant improvement: Manipulation of genes affecting quantitative traits. Crop Sci. 33:660-668.

Duncan, J.M., D.M. Kennedy, and E. Seemüller. 1987. Identities and pathogenicities of Phytophthora spp. causing root rot of raspberry. Plant Pathol. 36:276-289.

Durham, R.E. and S.S. Korban. 1994. Evidence of gene introgression in apple using RAPD markers. Euphytica 79:109-114.

Durham, R.E., P.C. Liou, F.G. Gmitter, Jr., and G.A. Moore. 1992. Linkage of restriction fragment length polymorphisms and isozymes in Citrus. Theor. Appl. Genet. 84:39-48.

Ehlenfeldt, M.K., A.W. Stretch, and A.D. Draper. 1993. Sources of genetic resistance to red ringspot virus in a breeding blueberry population. HortScience 28:207-208.

Emershad, R.L. and D.W. Ramming. 1994. Somatic embryogenesis and plant development from immature zygotic embryos of seedless grapes (Vitis vinifera L.). Plant Cell Rpt. 14:6-12.

Etzel, R.W. and J.R. Meyer. 1986. Resistance in blueberries to feeding and oviposition by the sharpnosed leafhopper Scaphtopius magdalensis (Provancher). J. Econ. Entomol. 79:1513-1515.

Fisk, H.J. and A.M. Dandekar. 1994. The introduction and expression of transgenes in plants. Scientia Hort. 55:5-36.

Fitch, M.M.M., R.M. Manshardt, D. Gonsalves, J.L. Slightom, and J.C. Sanford. 1990. Stable transformation of papaya via microprojectile bombardment. Plant Cell Rpt. 9:189-194.

Fjellstrom, R.G. and D.E. Parfitt. 1994. Development of an RFLP map for walnut. HortScience 29:529. (Abstr.)

Foolad, M.R., S. Arulsekar, and F. Bliss. 1994. Genetic linkage mapping in 
Prunus. HortScience 29:528. (Abstr.)

Gallott, J.C., R.C. Lamb, and H.S. Aldwinckle. 1985. Resistance to powdery mildew from small-fruited Malus cultivars. HortScience 20:1085-1087.

Gardner, R.G., J.N. Cummins, and H.S. Aldwinckle. 1980. Fire blight resistance in the Geneva apple rootstock breeding program. J. Amer. Soc. Hort. Sci. 105:907-912.

Garnsey, S.M. 1985. Virus and virus-like diseases of citrus and their impact on citrus production and germplasm selection. Fruit Var. J. 39:36-46.

Germain, E., F. Dosba, and E. Fos. 1994. Création de nouveaux porte-greffes de noyer "vigorisants" et tolerants au virus du cherry leaf roll. Proc. 8th Colloq. Fruit Research, Angers.

Gmitter, F.G., Jr., J.W. Grosser, and G.A. Moore. 1992. Citrus, p. 335-369. In: F.A. Hammerschlag and R.E. Litz (eds.). Biotechnology of perennial fruit crops. CAB Intl., Wallingford, U.K.

Graham, J. and R.J. McNichol. 1991. Regeneration and transformation of Ribes. Plant Cell Tissue Organ Cult. 24:91-95.

Graham, J., R.J. McNichol, and A. Kumar. 1990. Use of the GUS gene as a selectable marker for Agrobacterium-mediated transformation of Rubus. Plant Cell Tissue Organ Culture 20:35-39.

Greene, A.E. and R.F. Allison. 1994. Recombination between viral RNA and transgenic plant transcripts. Science 263:1423-1425.

Gupton, C.L. and B.J. Smith. 1991. Inheritance of resistance to Colletotrichum species in strawberry. J. Amer. Soc. Hort. Sci. 116:724-727.

Hall, H.K. 1990. Blackberry breeding. Plant Breeding Rev. 8:249-312.

Hammerschlag, F.A. 1988. Screening peaches in vitro for resistance to Xanthomonas campestris pv. pruni. J. Amer. Soc. Hort. Sci. 113:164-166.

Hammerschlag, F.A. and R.E. Litz (eds.). 1992. Biotechnology of perennial fruit crops. CAB Intl., Wallingford, U.K.

Hammerschlag, F.A., L.D. Owens, and A.C. Smigocki. 1989. Agrobacteriummediated transformation of peach cells derived from mature plants that were propagated in vitro. J. Amer. Soc. Hort. Sci. 114:508-510.

Hammerschlag, F.A. and A.C. Smigocki. 1994. Transgenic peach plants containing a cytokinin biosynthesis gene display altered growth in vitro and under greenhouse conditions. HortScience 29:454. (Abstr.)

Hansche, P.E. 1983. Response to selection, p. 154-171. In: J.N. Moore and J. Janick (eds.). Methods in fruit breeding. Purdue Univ. Press, West Lafayette, Ind.

Hassan, M.A., H.J. Swartz, G. Inamine, and P. Mullineaux. 1993. Agrobacterium tumefasciens-mediated transformation of several Rubus genotypes and recovery of transformed plants. Plant Cell Tissue Organ Cult. 33:9-17.

Haymes, K.M. and T.M. Davis. 1993. Agrobacterium-mediated transformation and regeneration of the diploid strawberry. Acta Hort. 348:440.

Hebert, D., J.R. Kikkert, F.D. Smith, and B.I. Reisch. 1993. Optimization of biolistic transformation of embryogenic grape cell suspensions. Plant Cell Rpt. 12:585-589.

Hemmat, M., N.F. Weeden, A.G. Manganaris, and D.M. Lawson. 1994. Molecular marker linkage map for apple. J. Hered. 85:4-11.

Hormaza, J.I., L. Dollo, and V.S. Polito. 1994. Molecular markers for early determination of sex of pistachio seedlings. HortScience 29:462. (Abstr.)

Hunter, D.M. 1993. Pear breeding for the 21st century-Program and progress at Harrow. Acta Hort. 338:377-383.

Hunter, D.M. and W.G. Bonn. 1994. Virulence of Erwinia amylovora strains on pear. HortScience 29:505. (Abstr.)

Jabco, J.P., W.B. Nesbitt, and D.J. Werner. 1985. Resistance of various classes of grapes to the bunch and muscadine forms of black rot. J. Amer. Soc. Hort. Sci. 110:762-765

James, D.J., A.J. Passey, and S.A. Baker. 1994. Stable gene expression in apple fruit tissues and segregation of transgenes in the progeny. Abstr. Fourth Intl. Congr. Plant Mol. Biol., Amsterdam, 19-24 June 1994. (Abstr.)

James, D.J., A.J. Passey, and D.J. Barbara. 1990. Agrobacterium-mediated transformation of the cultivated strawberry (Fragaria $\times$ ananassa Duch.) using disarmed binary vectors. Plant Sci. 69:79-94.

James, D.J., A.J. Passey, D.J. Barbara, and M. Bevan. 1989. Genetic transformation of apple (Malus pumila Mill.) using a disarmed Ti-binary vector. Plant Cell Rpt. 7:658-661.

Janick, J., R.E. Bagwill, and J.R. Nesbitt. 1983. Cultivar release and protection, p. 383-397. In: J.N. Moore and J. Janick (eds.). Methods in fruit breeding. Purdue Univ. Press, West Lafayette, Ind.

Jarrell, D.C., M.L. Roose, S.N. Traugh, and R.S. Kupper. 1992. A genetic map of citrus based on the segregation of isozymes and RFLPs in an intergeneric cross. Theor. Appl. Genet. 84:49-56.

Keep, E. 1989. Breeding red raspberries for resistance to diseases and pests. Plant Breeding Rev. 6:245-321.

Kennedy, D.M. and J.M. Duncan. 1991. Methods for assessing the resistance of raspberry genotypes to Phytophthora root rot. Plant Pathol. 40:387-394.

Kennedy, D.M. and J.M. Duncan. 1993. Occurrence of races in Phytophthora fragariae var. rubi on raspberry. Acta Hort. 352:555-562.

Knight, R.L. and F.H. Alston. 1969. Developments in apple breeding. Rpt. E. Malling Res. Sta. 1968:125-132.
Korban, S.S. and D.F. Dayton. 1983. Evaluation of Malus germplasm for resistance to powdery mildew. HortScience 18:219-220.

Laimer da Camara Machado, M., A. da Camara Machado, V. Hanzer, H. Weiss, F. Regner, H. Steinkellner, D. Mattanovich, R. Plail, E. Knapp, B. Kalthoff, and H. Katinger. 1992. Regeneration of transgenic plants of Prunus armeniaca containing the coat protein gene of plum pox virus. Plant Cell Rpt. 11:25-29.

Lande, R. 1992. Marker-assisted selection in relation to traditional methods of plant breeding, p. 437-451. In: H.T. Stalker and J.P. Murphy (eds.). Plant breeding in the 1990s. CAB Intl., Wallingford, U.K.

Lander, E.S. and D. Botstein. 1989. Mapping Mendelian factors underlying quantitative traits using RFLP linkage maps. Genetics 121:185-199.

Layne, R.E.C. 1966. Susceptibility of apricots to bacterial spot infection of foliage and fruit. Plant Dis. Rpt. 50:112-115.

Layne, R.E.C., C.H. Bailey, and L.F. Hough. 1968. Efficacy of transmission of fire blight resistance in Pyrus. Can. J. Plant Sci. 48:231-243.

Ling, P., F.G. Gmitter, Jr., L.W. Duncan, and S.Y. Xiao. 1994. Inheritance of citrus nematode resistance and its linkage with RAPD markers in citrus. HortScience 29:483. (Abstr.)

Luby, J.J., D.K. Wildung, C. Stushnoff, S.T. Munson, P.E. Read, and E.E. Hoover. 1986. 'Northblue', 'Northsky', and 'Northcountry' blueberries. HortScience 21:1240-1242.

Mante, S., P.H. Morgens, R. Scorza, J.M. Cordts, and A.M. Callahan. 1991. Agrobacterium-mediated transformation of plum (Prunus domestica L.) hypocotyl slices and regeneration of transgenic plants. Bio/Technology 9:853-857.

Martin, G.B., S.H. Brommonschenkel, J. Chunwongse, A. Frary, M.W. Ganal, R. Spivey, T. Wu, E.D. Earle, and S.D. Tanksley. 1993. Map-based cloning of a protein kinase gene conferring disease resistance in tomato. Science 262:1432-1436.

Martin, R.R. 1994. Genetic engineering of potatoes. Amer. Potato J. 71:347358.

Mathews, H., C. Cohen, W. Wagoner, J. Kellogg, V. Dewey, and R. Bestwick. 1994. Genetic transformation of red raspberry (Rubus idaeus L.) with a gene to control ethylene biosynthesis. HortScience 29:454. (Abstr.)

McGranahan, G.H. and P.B. Catlin. 1987. Juglans rootstocks, p. 411-450. In: R.C. Rom and R.F. Carlson (eds.). Rootstocks for fruit crops. Wiley, New York.

McGranahan, G.H., C.A. Leslie, A.M. Dandekar, S.L. Uratsu, and I.E. Yates. 1993. Transformation of pecan and regeneration of transgenic plants. Plant Cell Rpt. 12:634-638.

McGranahan, G.H., C.A. Leslie, S.L. Uratsu, and A.M. Dandekar. 1990. Improved efficiency of the walnut somatic embryo gene transfer system. Plant Cell Rpt. 8:512-516.

McGranahan, G.H., C.A. Leslie, S.L. Uratsu, L.A. Martin, and A.M. Dandekar. 1988. Agrobacterium-mediated transformation of walnut somatic embryos and regeneration of transgenic plants. Bio/Technology 6:800-804.

Mehlenbacher, S.A., J.N. Pinkerton, K.B. Johnson, and J.W. Pscheidt. 1994. Eastern filbert blight in Oregon. Acta Hort. 351:551-556.

Mehlenbacher, S.A., M.M. Thompson, and H.R. Cameron. 1991. Occurrence and inheritance of resistance to eastern filbert blight in 'Gasaway' hazelnut. HortScience 26:410-411.

Mehlenbacher, S.A., M.M. Thompson, J. Janick, E.B. Williams, F.H. Emerson, S.S. Korban, D.F. Dayton, and L.F. Hough. 1988. 'McShay' apple. HortScience 23:1091-1092.

Meyer, J.R. and J.R. Ballington. 1990. Resistance of Vaccinium spp. to the leafhopper Scaphytopius magdalensis (Homoptera:Cicadellidae). Ann. Entomol. Soc. Amer. 83:515-520.

Michelmore, R.W., I. Paran, and R.V. Kesseli. 1991. Identification of markers linked to disease resistance genes by bulked segregant analysis: A rapid method to detect markers in specific genomic regions using segregating populations. Proc. Natl. Acad. Sci. USA 88:9828-9832.

Mihatsch, H. and G. Mildenberger. 1967. Beiträge zur Vererbung der Mehltauresistenz bei Malus. III. Beobachtungen zum Frühselektionsproblem. Der Zuchter 37:25-32.

Milholland, R.D. and G.J. Galletta. 1969. Pathogenic variation among isolates of Botryosphaeria corticis on blueberry. Phytopathology 59:1540-1543.

Mircetich, S.M. and A. Rowhani. 1984. The relationship of cherry leaf roll virus and blackline disease of English walnut trees. Phytopathology 74:423-428.

Moore, G.A., A. Gutierrez-E., C. Jacono, M. McCaffery, and K. Cline. 1993. Production of transgenic citrus plants expressing the citrus tristeza virus coat protein gene. HortScience 28:513. (Abstr.)

Moore, G.A., C.C. Jacono, J.L. Neidigh, S.D. Lawrence, and K. Cline. 1992. Agrobacterium-mediated transformation of citrus stem segments and regeneration of transgenic plants. Plant Cell Rpt. 11:238-242.

Mortensen, J.A. 1968. The inheritance of resistance to Pierce's disease in Vitis. Proc. Amer. Soc. Hort. Sci. 92:331-337.

Mortensen, J.A. 1977. Segregation for resistance to black rot in selfed grape seedlings. Fruit Var. J. 31:59-60. 
Mortensen, J.A., L.H. Stover, and C.F. Balerdi. 1977. Sources of resistance to Pierce's disease in Vitis. J. Amer. Soc. Hort. Sci. 102:695-697.

Mullins, M.A., F.C.A. Tans, and D. Fasciotti. 1990. Agrobacterium-mediated genetic transformation of grapevines: Transgenic plants of Vitis rupestris Schelle and shoots of Vitis vinifera $\mathrm{L}$. Bio/Technology 8:1041-1045.

Nehra, M. and A. Wallin. 1992. Transient gene expression in strawberry (Fragaria $\times$ ananassa Duch.) protoplasts and the recovery of transgenic plants. Plant Cell Rpt. 11:105-108.

Nehra, S.N., R.N. Chibbar, K.K. Kartha, R.S.S. Datla, W.L. Crosby, and C. Stushnoff. 1990. Genetic transformation of strawberry by Agrobacterium tumefasciens using a leaf disk regeneration system. Plant Cell Rpt. 9:293298.

Norelli, J.L., H.S. Aldwinckle, and S.V. Beer. 1984. Differential host $\times$ pathogen interactions among cultivars of apple and strains of Erwinia amylovora. Phytopathology 74:136-139.

Parisi, L., Y. Lespinasse, J. Guillaumes, and J. Krüger. 1993. A new race of Venturia inaequalis virulent to apples with resistance due to the $V f$ gene. Phytopathology 83:533-537.

Paterson, A.H., S.D. Tanksley, and M.E. Sorrells. 1991. DNA markers in plant improvement. Adv. Agron. 46:39-90.

Perez, C., B. Fernandez, and R. Rodriguez. 1983. In vitro plantlet regeneration through asexual embryogenesis in cotyledonary segments of Corylus avellana L. Plant Cell Rpt. 2:226-228.

Pinkerton, J.N., K.B. Johnson, S.A. Mehlenbacher, and J.W. Pscheidt. 1993. Susceptibility of European hazelnut clones to eastern filbert blight. Plant Dis. 77:261-266.

Poehlman, J.M. 1987. Breeding field crops. 3rd ed. Van Nostrand Reinhold, New York.

Rajapakse, S., L.E. Belthoff, R. Scorza, R.E. Ballard, W.V. Baird, R. Monet, and A.G. Abbott. 1994. Genetic linkage mapping in peach. HortScience 29:529. (Abstr.)

Randhawa, P.S. and E.L. Civerolo. 1985. A detached-leaf bioassay for Xanthomonas campestris pv. pruni. Phytopathology 75:1060-1063.

Rodriguez, R., A. Rodriguez, A. Gonzalez, and C. Perez. 1989. Hazelnut (Corylus avellana L.), p. 127-160. In: Y.P.S. Bajaj (ed.). Biotechnology in agriculture and forestry. vol. 5. Trees II. Springer-Verlag, Berlin.

Rouselle, G.L. and C.N. Fortin. 1983. 'Rouville' et 'Richelieu': Deux cultivars de pommier résistant à la tavelure. Résumé des recherches. Agriculture Canada, Saint Jean-sur-Richelieu, Que. 12:288-289.

Rowland, L.J. and A. Levi. 1994. RAPD-based genetic linkage map of blueberry derived from a cross between diploid species (Vaccinium darrowi and V. elliottii). Theor. Appl. Genet. 87:863-868.

Schuerman, P.L. and A.M. Dandekar. 1994. Transformation of temperate woody crops: Progress and potentials. Scientia Hort. 55:101-124.

Scorza, R., J.M. Cordts, D.W. Ramming, and R.L. Emershad. 1994a. Transformation of grape (Vitis vinifera $\mathrm{L}$.) somatic embryos and regeneration of transgenic plants. J. Cellular Biochem. Suppl. 18A:102. (Abstr.)

Scorza, R., F.A. Hammerschlag, T.W. Zimmerman, and J.M. Cordts. 1995. Transformation of peach and plum. In: Y.P.S. Bajaj (ed.). Biotechnology in agriculture and forestry. Springer-Verlag, Berlin. (In press.)

Scorza, R. and P.L. Pusey. 1984. A wound-freezing inoculation technique for evaluating resistance to Cytospora leucostoma in young peach trees. Phytopathology 74:569-572.

Scorza, R., M. Ravelonandro, A.M. Callahan, J.M. Cordts, M. Fuchs, J. Dunez, and D. Gonsalves. 1994b. Transgenic plums (Prunus domestica L.) express plum pox virus coat protein gene. Plant Cell Rpt. 14:18-22.

Scott, D.H., A.D. Draper, and G.J. Galletta. 1984. Breeding strawberries for red stele resistance. Plant Breeding Rev. 2:195-214.

Serres, R., E. Stang, D. McCabe, D. Russel, D. Mahr, and B. McCown. 1992. Gene transfer using electric discharge particle bombardment and recovery of transformed cranberry plants. J. Amer. Soc. Hort. Sci. 117:174-180.
Sherman, W.B., B.L. Topp, and P.M. Lyrene. 1992. Breeding low-chill Japanese-type plums for subtropical climates. Acta Hort. 317:149-153.

Sherman, W.B., C.E. Yonce, W.R. Okie, and T.G. Beckman. 1989. Paradoxes surrounding our understanding of plum leaf scald. Fruit Var. J. 43:147-151.

Sidhu, G.S. 1987. Host-parasite genetics. Plant Breeding Rev. 5:393-433.

Simmonds, N.W. 1979. Principles of crop improvement. Longman, New York.

Sjulin, J.M. 1989. Expression of partial resistance to cherry leaf spot in cultivars of sweet, sour, duke, and European ground cherry. Plant Dis. 73:56-61.

Smigocki, A.C. and F.A. Hammerschlag. 1991. Regeneration of plants from peach embryo cells infected with a shooty mutant strain of Agrobacterium. J. Amer. Soc. Hort. Sci. 116:1092-1097.

Soost, R.K. and J.W. Cameron. 1975. Citrus, p. 507-540. In: J. Janick and J.N. Moore (eds.). Methods in fruit breeding. Purdue Univ. Press, West Lafayette, Ind.

Stone, J.K., K.B. Johnson, J.N. Pinkerton, and J.W. Pscheidt. 1992. Natural infection period and susceptibility of vegetative seedlings of European hazelnut to Anisogramma anomala. Plant Dis. 76:348-352.

Tennant, P.F., C. Gonsalves, K.S. Ling, M. Fitch, R. Manshardt, J.L. Slightom, and D. Gonsalves. 1994. Differential protection against papaya ringspot virus isolates in coat protein gene transgenic papaya and classically crossprotected papaya. Phytopathology 84:1359-1366.

Thompson, J.M., R.H. Zimmerman, and T. van der Zwet. 1975. Inheritance of fire blight resistance in Pyrus. I. A dominant gene Se causing sensitivity. J. Hered. 66:259-264.

Thompson, T.E. and L.J. Grauke. 1994. Genetic resistance to scab disease in pecan. HortScience 29:1078-1080.

Topp, B.L., W.B. Sherman, D.A. Huber, and S.B. Linda. 1993a. Combining abilities of five Japanese plum cultivars for resistance to Xanthomonas stem canker. HortScience 28:727-729.

Topp, B.L., W.B. Sherman, and R.E. Stall. 1991. Comparison of rating methods for bacterial spot resistance in Japanese-type plum. Fruit Var. J. 45:70-74.

Topp, B.L., W.B. Sherman, R.E. Stall, G.V. Minsavage, and C.J. Wilcox. 1993b. Comparison of greenhouse methods for assessing resistance to bacterial leaf spot in plum. J. Amer. Soc. Hort. Sci. 118:667-671.

van de Weg, W.E., S. Giezen, J.L. Maas, and G.J. Galletta. 1993a. Identification of genes for resistance to Phytophthora fragariae in strawberry. Acta Hort. 348:137-138.

van de Weg, W.E., S. Giezen, J.L. Maas, and G.J. Galletta. 1993b. Research on screening methods for resistance to Phytophthora fragariae in strawberry. Acta Hort. 348:513-514.

van der Plank, J.E. 1982. Host-pathogen interaction in plant disease. Academic, New York.

Watkins and J.M. Werts. 1971. Pre-selection for Phytophthora cactorum (Leb. and Cohn) Schroet. resistance in apple seedlings. Ann. Appl. Biol. 67:153156.

Werner, D.J., D.F. Ritchie, D.W. Cain, and E.I. Zehr. 1986. Susceptibility of peaches and nectarines, plant introductions, and other Prunus species to bacterial spot. HortScience 21:127-130.

Williams, E.B. and J. Kuc. 1969. Resistance in Malus to Venturia inaequalis. Annu. Rev. Phytopathol. 7:233-246.

Woeste, K., D. Shaw, and G. McGranahan. 1994. A comparison of genomic and morphological evaluation for selection in interspecific backcross populations of walnut. HortScience 29:462. (Abstr.)

Woeste, K.E., G.H. McGranahan, and M.N. Schroth. 1992. Variation among Persian walnuts in response to inoculation with Xanthomonas campestris pv. juglandis. J. Amer. Soc. Hort. Sci. 117:527-531.

Ye, X., S.K. Brown, R. Scorza, J.C. Cordts, and J. Sanford. 1994. Genetic transformation of peach tissues by particle bombardment. J. Amer. Soc. Hort. Sci. 119:367-373.

Yu, X. 1993. Micropropagation and regeneration of hazelnut (Corylus species). $\mathrm{PhD}$ Diss., Oregon State Univ., Corvallis. 


\title{
Statistical Analysis of Disease Reaction Data Using Nonparametric Methods
}

\author{
K.M. Eskridge ${ }^{1}$ \\ Department of Biometry, University of Nebraska, Lincoln, NE 68583-0712
}

Plant breeders developing disease-resistant horticultural crops need flexible and powerful statistical methods to compare treatments efficiently. The most commonly used statistical methods are those based on analysis of variance (ANOVA), regression, and correlation. The valid use of these methods requires that the data have 1) normally distributed responses, 2) constant error variance, 3) independently distributed errors, and 4) a correctly specified model. However, many plant disease experiments yield data that do not adhere to these standard assumptions. For example, in an experiment involving population levels of a pathogen, rarely will population levels be normally distributed. Field counts of the number of nondiseased individuals in a plot many times will have different variances for various treatments. Laboratory experiments measuring the amount of a particular chemical compound produced by a pathogen may have a few cultures with extremely high amounts of the compound, indicating the presence of outliers.

Using standard methods (e.g., ANOVA) on data such as these is questionable for several reasons. Any conclusions based on unreasonable assumptions are suspect and may be wrong simply because the chosen method of analysis forces assumptions on the data that cannot be justified. More importantly, use of inappropriate statistical methods many times reduces the chances of correctly identifying differences that would have been found had the correct method been used.

Nonparametric (NP) statistical methods can be useful alternatives to classical statistical methods. Nonparametric methods require fewer assumptions about the data, but in many cases, allow one to draw valid conclusions with considerably better chances of detecting differences between treatments. The objective of this paper is to demonstrate how nonparametric statistical methods can be simply applied to data likely to result from plant disease experiments.

\section{NONPARAMETRIC METHODS AND APPLICATIONS}

\section{ANOVA}

Many plant disease experiments involve measuring a quantitative response on each of several treatments. The main goal is to determine if responses differ among treatments. Some form of ANOVA is usually appropriate for testing equality of treatment effects. The specific type of ANOVA will depend on 1) the experiment design and 2 ) the distribution of the response variable. Nonparametric methods can be applied easily to several of the most commonly used designs, assuming the hypothesis of interest is no difference between true treatment medians. Use of medians is preferable to means when data are not normally distributed, because medians are less sensitive to extremes. However, when data are normal, the true mean equals the true median and statements about the medians apply to the means.

Completely randomized design (CRD). This type of experiment design consists of several experimental units being randomly assigned to each treatment, and a quantitative response is obtained from each unit. Nonparametric statistical methods are easily applied to data from a CRD. A simple approach is to use a nonparametric ANOVA based on ranks (Conover and Iman, 1981). The procedure is to 1) assign ranks

Received for publication 20 Oct. 1994. Accepted for publication 17 Nov. 1994 Published as paper no. 10792, Journal Series, Nebraska Agricultural Research Division, Univ. of Nebraska, Lincoln. The cost of publishing this paper was defrayed in part by the payment of page charges. Under postal regulations, this paper therefore must be hereby marked advertisement solely to indicate this fact.

${ }^{1}$ Associate Professor. to all data points; 2) using the classical CRD ANOVA, analyze the ranks as if they were the observed responses; and 3) if the F test is significant, conclude at least two treatment medians differ and use a multiple comparison method (e.g., LSD) on the ranked data to identify which treatments differ.

To illustrate the approach, data were taken from a study on the population levels of Xanthomonas campestris pv. phaseoli (Smith) Dye (Xcp) on dry beans (Phaseolus vulgaris L.) (Ishimaru et al., 1991). Xcp population levels were obtained on 10 leaves from each of two fields with different dry bean cultivars (Table 1). Population levels were skewed and nonnormally distributed $(P<0.012)$, and variances were extremely heterogeneous, severely violating assumptions of classical ANOVA. Nonparametric ANOVA on ranks revealed highly significant differences between the two fields $(\mathrm{F}=12.60 ; P=0.0023)$, while classical ANOVA indicated slight significance $(\mathrm{F}=5.87 ; P=$ 0.026). [The Appendix contains the necessary SAS statements to compute the nonparametric CRD ANOVA (SAS, 1992).] The nonparametric ANOVA appeared to have substantially more power because its $P$ value was more than 10 times smaller than that from the classical ANOVA.

Randomized complete block design (RCBD). This type of design is conducted so that experimental units are grouped into homogeneous blocks, with treatments being randomly assigned to units within each block and with a quantitative response obtained from each unit. The RCBD can be analyzed using nonparametric methods by 1) assigning ranks to data points within each block separately and 2) analyzing the ranks as if they are the observed responses using the classical RCBD ANOVA (Conover and Iman, 1981).

To demonstrate the use of this approach, data were taken from a study on the oxalic acid production of four strains of the fungus Sclerotinia sclerotiorum (Lib.) de Bary (Godoy et al., 1990; Table 2). One mycelium of each strain was prepared beginning at week 1, and the entire process was repeated for three more weeks, with each week serving as a block. Oxalic acid concentrations (milligrams per gram of dry weight of mycelium) were obtained for each mycelium. Variances differed extremely, with the ratio of the smallest to largest being $1.9 \times$ $10^{6}$. Use of classical ANOVA was not justified. Nonparametric ANOVA on the within-block ranks rejected equality of treatment medians at a high level of significance $(P<0.0001)$, while classical ANOVA showed only weak significance $(P=0.0478)$. (The Appendix contains the necessary SAS statements to compute a nonparametric RCBD ANOVA.) Comparison of the $P$ values apparently illustrated the improved power of the nonparametric approach. Use of the LSD on

Table 1. Population levels [colony forming units (CFU)] of foliar Xanthomonas campestris pv. phaseoli on dry beans from two fields (A and B), ranks, and field medians and variances (Ishimaru et al., 1991).

\begin{tabular}{|c|c|c|c|}
\hline \multicolumn{2}{|r|}{ Field A } & \multicolumn{2}{|c|}{ Field B } \\
\hline$\overline{\mathrm{CFU}}$ & Rank & $\mathrm{CFU}$ & Rank \\
\hline $\begin{array}{l}195,000 \\
\end{array}$ & 9 & 4,500 & 5 \\
\hline $1,810,000$ & 14 & $55,550,000$ & 19 \\
\hline 325,000 & 11 & $6,900,000$ & 15 \\
\hline 5,750 & 6 & $66,050,000$ & 20 \\
\hline 100 & 1 & $1,370,000$ & 12 \\
\hline 250,000 & 10 & $9,200,000$ & 16 \\
\hline 17,250 & 8 & $1,400,000$ & 13 \\
\hline 300 & 2 & 10,200 & 7 \\
\hline 2700 & 4 & $15,200,000$ & 17 \\
\hline 1700 & 3 & $34,550,000$ & 18 \\
\hline Median & 11,500 & & \\
\hline Variance & $3.1 \times 10^{11}$ & & \\
\hline
\end{tabular}


Table 2. Oxalic acid concentration (milligrams per gram) from four strains of Sclerotinia sclerotiorum mycelia for each of 4 weeks (blocks), ranks in parentheses, strain medians, and variances (Godoy et al., 1990).

\begin{tabular}{llccc}
\hline & \multicolumn{5}{c}{ Strain } \\
\cline { 2 - 5 } Week & \multicolumn{1}{c}{1} & \multicolumn{1}{c}{5} & 6 & 7 \\
\hline 1 & $2.40(4)$ & $0.23(3)$ & $0.00(1)$ & $0.01(2)$ \\
2 & $2.30(3)$ & $7.03(4)$ & $0.01(1)$ & $0.02(2)$ \\
3 & $5.01(3)$ & $26.93(4)$ & $0.02(2)$ & $0.01(1)$ \\
4 & $2.67(3)$ & $12.05(4)$ & $0.05(2)$ & $0.00(1)$ \\
Medians & $3.71 \mathrm{~A}^{z}$ & $9.54 \mathrm{~A}$ & $0.02 \mathrm{~B}$ & $0.02 \mathrm{~B}$ \\
Variance & 1.65 & 128.45 & $4.6 \times 10^{-4}$ & $6.6 \times 10^{-5}$ \\
\hline
\end{tabular}

${ }^{2}$ Two medians with the same letters do not differ at $\alpha=0.05$.

the ranked data revealed that strains 1 and 5 differed from strains 6 and $7(P<0.05)$, but no difference was detected between strains 1 and 5, nor between strains 6 and 7 (Table 2).

Analysis of other designs and treatment structures. Other types of experiment designs may be analyzed using similar ranking procedures. Koch (1970) demonstrated the use of nonparametric ANOVA for a split-split plot design. Conover (1980) and Conover and Iman (1981) discussed application of rank tests for other types of designs. Scheirer et al. (1976) presented rank methods for analyzing a factorial treatment structure.

\section{Correlation and regression analysis}

Many times, plant disease experiments involve measuring the strength of association between two quantitative variables. When both of these variables are normally distributed, estimates and tests are appropriately based on the classical Pearson product-moment correlation coefficient (Snedecor and Cochran, 1976). However, use of classical correlations is not justified when either one or both variables are far from normal. Spearman's rank correlation $\left(r_{s}\right)$ is a nonparametric correlation method that does not require any specific type of distribution and can be readily applied to non-normal quantitative variables (Conover, 1980). This approach proceeds by 1) assigning ranks to both variables individually and 2) computing Pearson's product-moment correlation coefficient based on these ranks.

Rank correlation analysis was used by Godoy et al. (1990) to measure the association between oxalic acid production and mycelia biomass of the fungus $S$. sclerotiorum (Table 3 ). Oxalic acid concentration was extremely non-normally distributed $(P<0.01)$, invalidating the use of classical correlation analysis. Rank correlation was appropriate and resulted in a correlation between oxalic acid and biomass of $\mathrm{r}_{\mathrm{s}}=+0.58$, which was significantly different from zero $(P$ $<0.02$ ). (The Appendix contains the necessary SAS statements to

Table 3. Oxalic acid (milligrams per gram) and mycelia biomass of the fungus Sclerotinia sclerotiorum, ranks, and rank correlation coefficient $\left(\mathrm{r}_{\mathrm{s}}\right)($ Godoy et al., 1990).

\begin{tabular}{lrrr}
\hline \hline & Oxalic acid & & \multicolumn{2}{c}{ Biomass } \\
\cline { 4 - 4 } Value & Rank & Value & Rank \\
\hline 2.40 & 11.0 & 0.14 & 1.0 \\
0.23 & 9.0 & 0.17 & 2.0 \\
0.00 & 1.5 & 0.26 & 6.5 \\
0.01 & 4.0 & 0.27 & 8.0 \\
2.30 & 10.0 & 0.45 & 14.0 \\
7.03 & 14.0 & 0.42 & 12.0 \\
0.01 & 4.0 & 0.21 & 4.0 \\
0.02 & 6.5 & 0.20 & 3.0 \\
5.01 & 13.0 & 0.47 & 15.0 \\
26.93 & 16.0 & 0.52 & 16.0 \\
0.02 & 6.5 & 0.31 & 9.5 \\
0.01 & 4.0 & 0.31 & 9.5 \\
2.67 & 12.0 & 0.41 & 11.0 \\
12.05 & 15.0 & 0.44 & 13.0 \\
0.05 & 8.0 & 0.26 & 6.5 \\
0.00 & 1.5 & 0.24 & 5.0 \\
Rank correlation $\mathrm{r}_{\mathrm{s}}=+0.58^{*}$ & &
\end{tabular}

*Significant at $\alpha=0.05$. compute a nonparametric rank correlation analysis.) This rank correlation showed a fairly strong association between oxalic acid and biomass and provided a valid $P$ value, whereas use of classical correlation and its $P$ value was clearly invalid due to non-normality. Note that, in the ranking of the variables, some data values were tied and the mean rank was assigned to the tied values (Table 3). For a further discussion of ties, consult Conover (1980).

Sometimes, plant disease experiments require use of simple or multiple regression. Theil (1950) presented a simple nonparametric method of estimating the slope and intercept for a simple linear regression. Conover (1980) discussed how to test for zero slope and how to use rank analysis with multiple regression.

\section{Categorical data analysis}

Categorical variables are common in plant disease experiments. Simple examples are: a seed is either viable or not; a line is either highly resistant, moderately resistant, or susceptible to a disease; a plant is one of four cultivars, etc. This type of data requires analyses different from the methods previously discussed because frequencies are analyzed instead of quantitative responses. When the dependent variable has I categories and there is one independent variable with $\mathrm{J}$ categories, data may be analyzed using contingency table analysis (Conover, 1980). The null hypothesis is that the probability of a particular response category $(\mathrm{i}=1, \ldots \mathrm{I})$ is homogeneous across the $\mathrm{J}$ treatments. This hypothesis is first tested using an overall chi-square statistic. The chi-square statistic $\left(\chi^{2}\right)$ is based on cell deviations of observed from expected frequencies, assuming $\mathrm{H}_{0}$ is true. Large deviations, and thus large chi-square values, tend to refute $\mathrm{H}_{0}$ because the expected values that are based on $\mathrm{H}_{0}$ are poor predictions of what was observed. When a large chi-square value rejects $\mathrm{H}_{0}$, the table may be subdivided into smaller tables, and chi-square analyses can be used to identify how the treatments differ.

To demonstrate the method, data from two resistant and two susceptible dry bean cultivars were evaluated for response to common bacterial blight pathogen (Aggour et al., 1989). About 30 seeds from each cultivar were spray-inoculated with Xcp directly before planting. Viable seedlings were then evaluated for symptoms (+ or - ) (Table 4). For cultivars with 30 seedlings, the expected number of seedlings with symptoms was $30 \times$ probability that a seed had symptoms. If the null hypothesis was true, then the estimated probability that a seed had symptoms was $38 / 121$, the total number of experimental seedlings with symptoms over the total number of seedlings. Thus, the expected number of seedlings with symptoms out of 30 was $30 \times(38 / 121)=$ 9.42. Similar reasoning gave the expected frequencies of symptomless seedlings. For a cell in the $2 \times 4$ table ( $I=2$ responses, $J=4$ cultivars; Table 4 ), the cell chi-square value was computed as the squared

Table 4. Frequency of seedlings of dry bean cultivars with or without common bacterial blight symptoms and chi-square values (Aggour et al., 1989).

\begin{tabular}{|c|c|c|}
\hline \multirow[b]{2}{*}{ Variable } & \multicolumn{2}{|c|}{ Symptoms } \\
\hline & Yes & No \\
\hline \multicolumn{3}{|l|}{ Cultivars } \\
\hline \multicolumn{3}{|l|}{ All, } \\
\hline Bac-6 & 2 & 29 \\
\hline V & 16 & 14 \\
\hline $\mathrm{PC}$ & 13 & 17 \\
\hline GNT & 7 & 23 \\
\hline \multicolumn{3}{|l|}{$\chi^{2} 18.546^{*}$} \\
\hline \multicolumn{3}{|l|}{ Resistant } \\
\hline Bac-6 & 2 & 29 \\
\hline GNT & 7 & 23 \\
\hline \multicolumn{3}{|l|}{$\chi^{2} 3.455$} \\
\hline \multicolumn{3}{|l|}{ Susceptible } \\
\hline V & 16 & 14 \\
\hline PC & 13 & 17 \\
\hline \multicolumn{3}{|l|}{$\chi^{2} \quad 0.602$} \\
\hline \multicolumn{3}{|l|}{ Bean type } \\
\hline Resistant & 9 & 52 \\
\hline Susceptible & 29 & 31 \\
\hline$\chi^{2} 15.832^{*}$ & & \\
\hline
\end{tabular}


deviation of observed from expected divided by expected. The overall chi-square statistic $\chi^{2}$ was the sum of all of the cell chi-square values. With these data, $\chi^{2}=18.546(\mathrm{df}=3)$, which was significant at $P<$ 0.001 . The data strongly refuted the null hypothesis of no difference among probabilities of symptoms across the four bean cultivars.

Although the overall chi-square strongly indicated differences among cultivars, it was not clear how the cultivars differed. Using the same ideas as with analyzing the $2 \times 4$ table, chi-square analysis was conducted on three $2 \times 2$ tables. One $2 \times 2$ table evaluated the differences among susceptible and resistant cultivars (Table $4 ; \chi^{2}=$ $15.832, \mathrm{df}=1, P<0.001)$. Another $2 \times 2$ table evaluated differences among the two resistant cultivars $\left(\chi^{2}=3.455, \mathrm{df}=1, P>0.05\right)$, while the third tested for differences between the two susceptible cultivars $\left(\chi^{2}=0.602\right.$, df $\left.=1, P>0.05\right)$. Based on these tables, the overall hypothesis was rejected due to resistant lines differing from the susceptible cultivars.

Other categorical response methods. Two-way contingency tables are restricted to a single treatment factor, which limits the usefulness of the method to simple experiments. However, many of the fundamental ideas of contingency tables extend to more than two dimensions and allow for the analysis of main effects and interactions of more complicated designs (Agresti, 1990; Freeman, 1987).

When the treatment variables are categorical and the response variable is binary, one approach is to use weighted least squares (Agresti, 1990). This method results in sums of squares that are appropriate for testing hypotheses of homogeneity of proportions for main effects and interactions in a manner similar to classical ANOVA. The idea of this approach is to obtain estimates that minimize the weighted error sums of squares where the weight of each proportion ( ) is the inverse of its variance $n_{i} /[(1-\quad)]$. These estimates then are used to obtain sums of squares for each of the relevant hypotheses. If a null hypothesis is true, the sums of squares has a chi-square distribution with the degrees of freedom from the relevant hypothesis. Appropriate use of the weight statement in SAS PROC GLM may be used to compute weighted sums of squares; however, SAS PROC CATMOD is somewhat easier to use because weights are automatically computed for each proportion (see Appendix).

I will use data from a study on the inheritance of common bacterial blight resistance in dry beans to illustrate the method (Arnaud-Santana et al., 1994). Seed from $64 \mathrm{~F}_{3} \mathrm{BC}_{2}$ recombinant inbred lines was obtained from two parental crosses (PC-50 x XAN-159, PC-50 x BAC-6), where PC-50 was a susceptible recurrent parent and the other two parents were resistant. Pods were inoculated with the common bacterial blight pathogen at the beginning of the pod suture. Seeds

Table 5. Number and proportion of diseased dry bean seeds for two locations (LOC) within the pod, two resistant parents (NR_PAR), and weighted least squares analysis of variance table (Arnaud-Santana et al., 1994)

\begin{tabular}{|c|c|c|c|}
\hline \multirow[b]{2}{*}{$\begin{array}{l}\text { Nonrecurrent } \\
\text { parent/response }\end{array}$} & \multicolumn{2}{|c|}{ Location } & \multirow[b]{2}{*}{ Total } \\
\hline & $\begin{array}{l}\text { Near } \\
\text { point }\end{array}$ & $\begin{array}{c}\text { Away from } \\
\text { point }\end{array}$ & \\
\hline \multicolumn{4}{|l|}{ BAC-6 } \\
\hline Proportion & 0.611 & 0.442 & 0.503 \\
\hline Number & 422 & 536 & 958 \\
\hline Total & 691 & 1214 & 1905 \\
\hline \multicolumn{4}{|l|}{ XAN159 } \\
\hline Proportion & 0.690 & 0.555 & 0.605 \\
\hline Number & 442 & 607 & 1049 \\
\hline Total & 641 & 1093 & 1734 \\
\hline \multicolumn{4}{|l|}{ Total } \\
\hline Proportion & 0.649 & 0.496 & 0.552 \\
\hline Number & 864 & 1143 & 2007 \\
\hline Total & 1332 & 2307 & 3639 \\
\hline Source & $\mathrm{df}$ & Chi-square & $P^{z}$ \\
\hline Intercept & 1 & $\overline{4766.48}$ & 0.0000 \\
\hline NR_PAR & 1 & 33.53 & 0.0000 \\
\hline LOC & 1 & 83.14 & 0.0000 \\
\hline NR_PAR $\times$ LOC & 1 & 1.11 & 0.2929 \\
\hline
\end{tabular}

from these lines were classified either next to the point of inoculation (or not) and whether symptoms were present after plating. The weighted least squares approach was used where the treatment variables were nonrecurrent parent (NR_PAR) and location of the seed in the pod (LOC), while the response variable was the proportion of diseased seeds for each parent-location combination.

Parent type and location did not interact $(P>0.05)$ regarding proportion of diseased seeds, as indicated by a nonsignificant sums of squares (chi-square) for interaction (Table 5). However, the nonrecurrent parent and location main effects were highly significant $(P<$ $0.05)$. BAC-6 had a smaller proportion of diseased seeds than XAN159 and seeds next to the point of inoculation had a higher chance of expressing symptoms.

\section{DISCUSSION}

Nonparametric methods are useful for the analysis of data from plant disease experiments. These methods require fewer assumptions and are often more powerful than the classical methods (see Iman et al., 1984). Many of these methods are conceptually similar to the classical statistical methods, and their application is generally accessible to horticultural scientists not possessing a detailed knowledge of statistics. Results from nonparametric methods are reported in a manner similar to results from standard methods. For example, treatment medians are given instead of means, and Spearman's rather than Pearson's correlation is reported.

I need to emphasize that nonparametric methods do have assumptions, although many methods are insensitive to violation of these assumptions (Conover, 1980). CRD and RCBD rank tests require that the underlying distributions for the treatments differ only by their medians, if at all. The RCBD rank test further assumes there is no block $\times$ treatment interaction. The methods presented above all require "large" sample sizes to be valid. [See Conover (1980) for required sample sizes for the above tests.] However, with "small" sample sizes, "exact" tests that provide the exact $P$ value are available for most of these methods (Conover, 1980).

\section{Literature Cited}

Aggour, A.R., D.P. Coyne, A.K. Vidaver, and K.M. Eskridge. 1989. Transmission of the common blight pathogen in bean seed. J. Amer. Soc. Hort. Sci. 114:1002-1008.

Agresti, A. 1990. Categorical data analysis. Wiley, New York.

Arnaud-Santana, E., D.P. Coyne, K.M. Eskridge, and A.K. Vidaver. 1994. Inheritance; low correlations of leaf, pod, and seed reactions to common blight disease in common beans; and implications for selection. J. Amer. Soc. Hort. Sci. 119:116-121.

Conover, W.J. 1980. Practical nonparametric statistics. 2nd ed. Wiley, New York.

Conover, W.J. and R.L. Iman. 1981. Rank transformation as a bridge between parametric and nonparametric statistics. Amer. Stat. 33(3):124-129.

Freeman, D.H. 1987. Applied categorical data analysis. Marcel Dekker, New York.

Godoy, G., J.R. Steadman, M.B. Dickman, and R. Dam. 1990. Use of mutants to demonstrate the role of oxalic acid in pathogenicity of Sclerotinia sclerotiorum on Phaseolus vulgaris. Physiol. Mol. Plant Pathol. 37:179191.

Iman, R.L., S.C. Hora, and W.J. Conover. 1984. Comparison of asymptotically distribution-free procedures for the analysis of complete blocks. J. Amer. Stat. Assn. 79:674-685.

Ishimaru, C.A., K.M. Eskridge, and A.K. Vidaver. 1991. Distribution analyses of epiphytic populations of Xanthomonas campestris pv. phaseoli on dry beans. Phytopathology 81:262-268.

Koch, G.G. 1970. The use of non-parametric methods in the statistical analysis of a complex split plot experiment. Biometrics 26:105-128.

SAS Institute. 1992. SAS user's guide: Statistics. vols. 1 and 2. SAS Institute, Cary, N.C.

Scheirer, C.J., W.S. Ray, and N. Hare. 1976. The analysis of ranked data derived from completely randomized factorial designs. Biometrics 32:429434.

Snedecor, G.W. and W.G. Cochran. 1976. Statistical methods. 6th ed. Iowa State Univ. Press, Ames.

Theil, H. 1950. A rank invariant method of linear and polynomial regression analysis. Indagationes Mathematicae 12:85-91. 


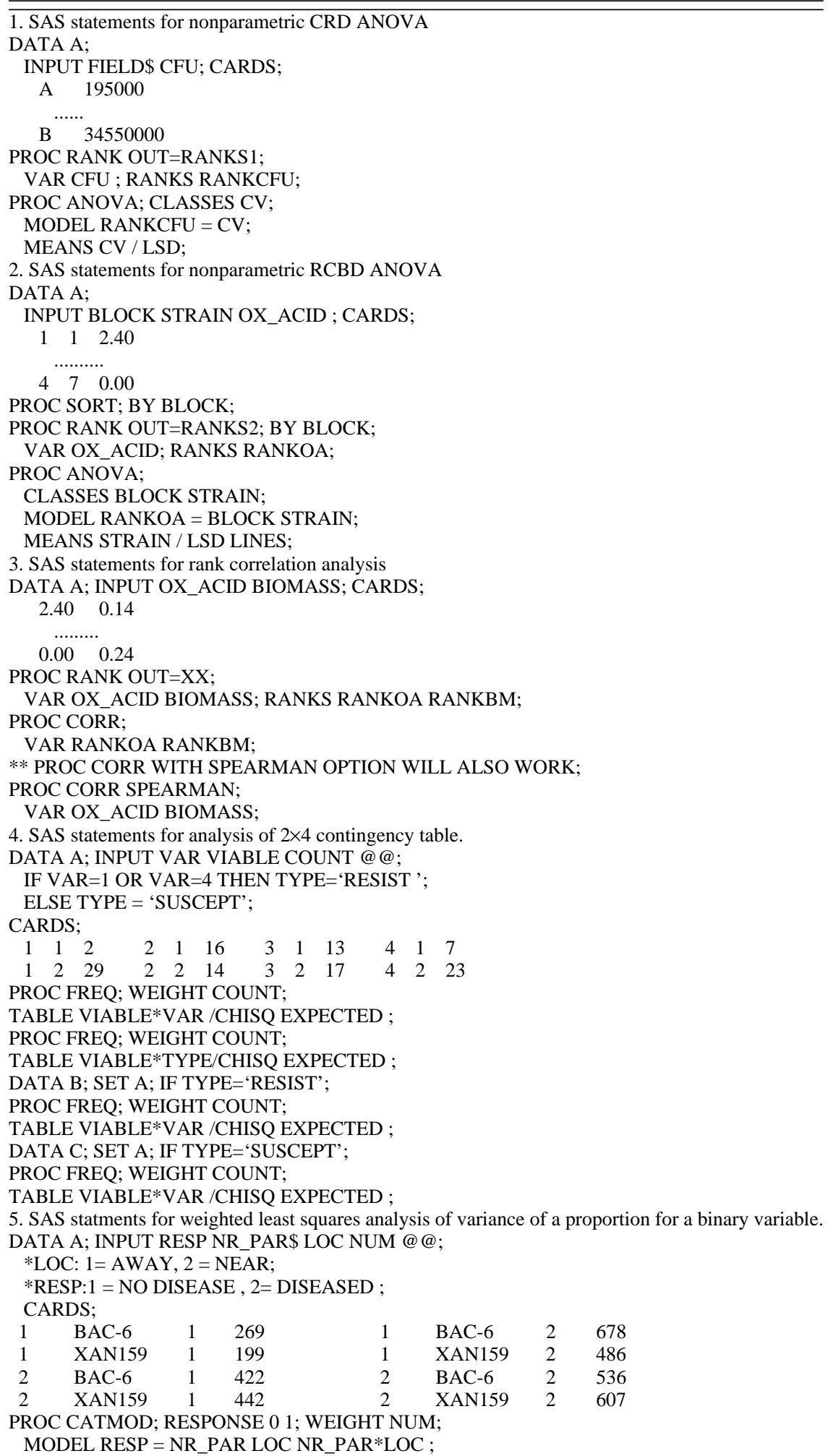

